(n)

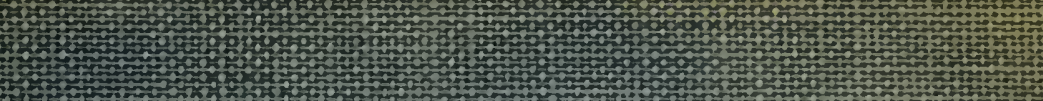

How

H.

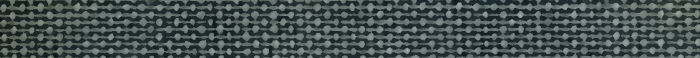

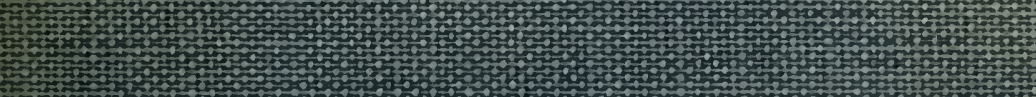

Hor

How

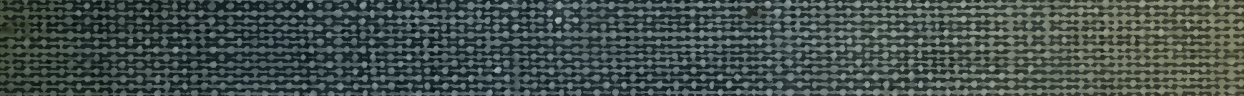

Fon

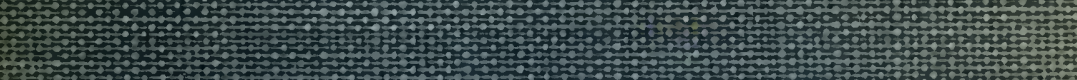

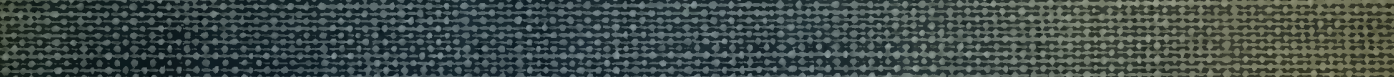

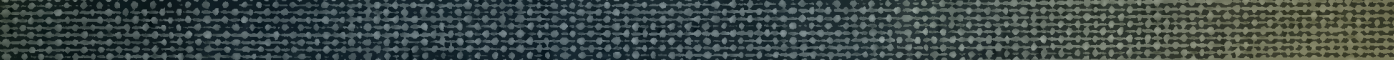

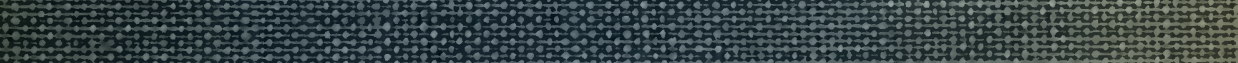

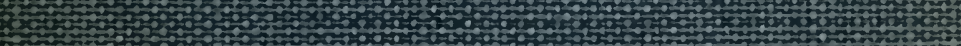

H.

H.

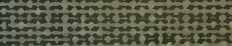

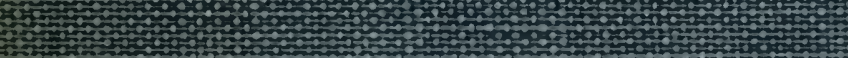

W

H. 7 H

H.

H.

Har.

Hor

a

Hojo,

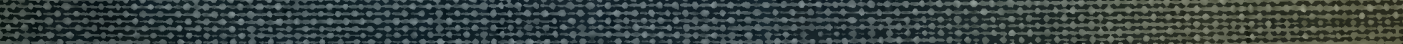
tis

Hothon

G5

T. 


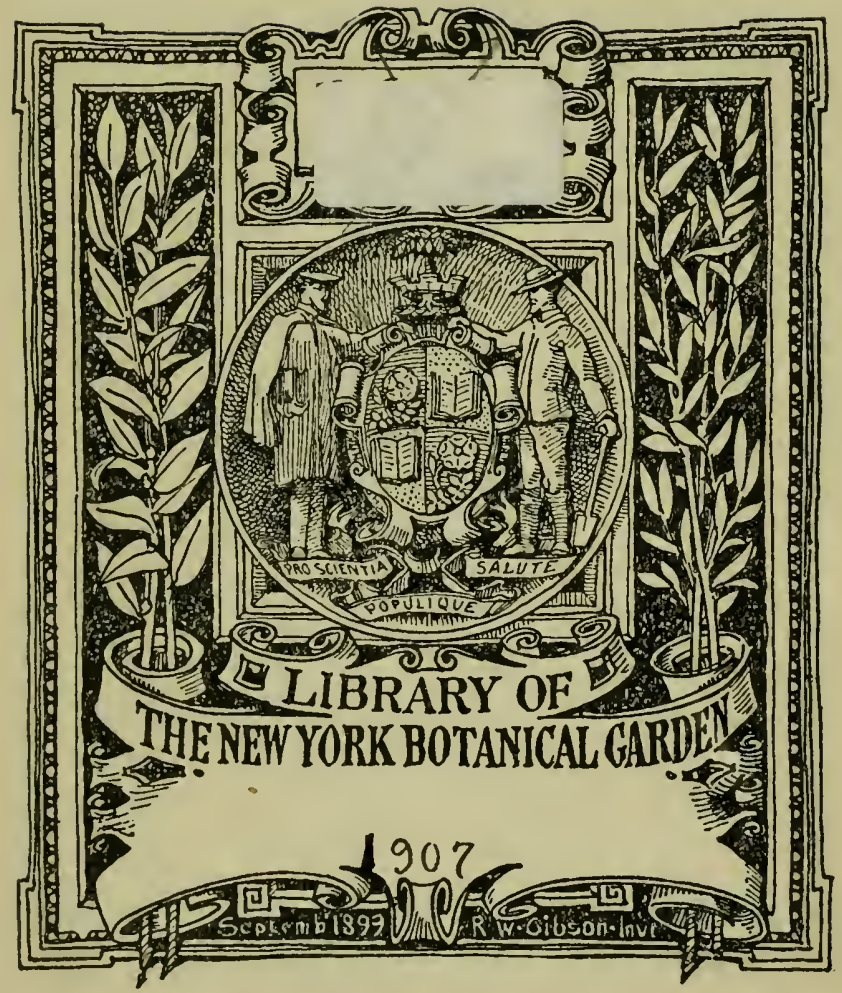




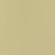





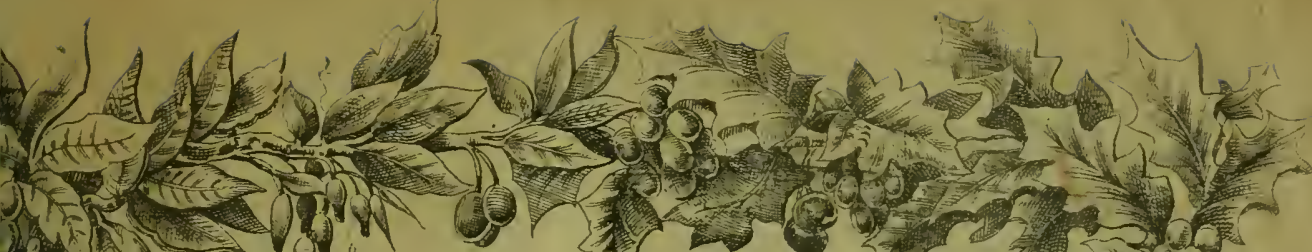
Jy
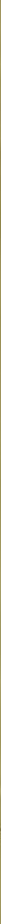

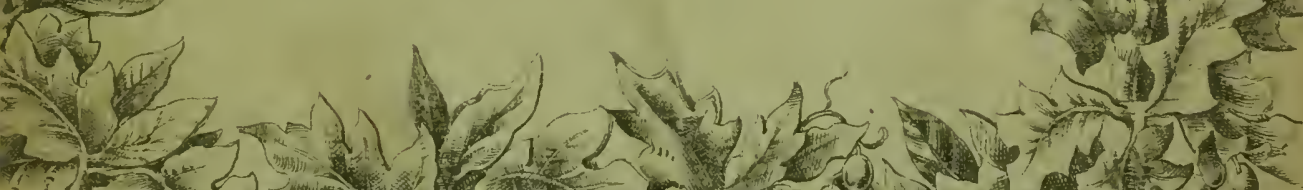

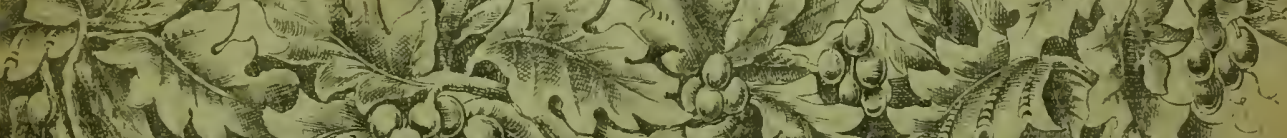

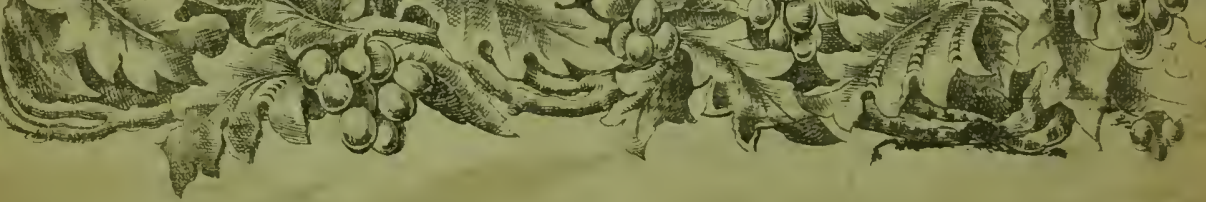





\section{ВСЕОБILІАЯ Ф.JOPA}

Д Л Я

.I Ю Б И Т Е .І Е Ӥ. 


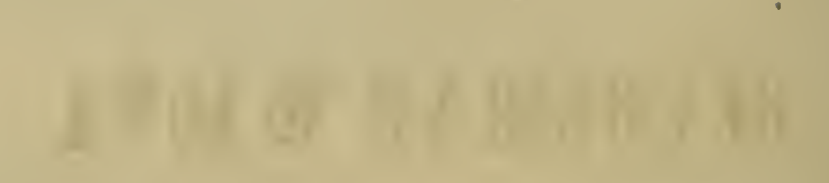

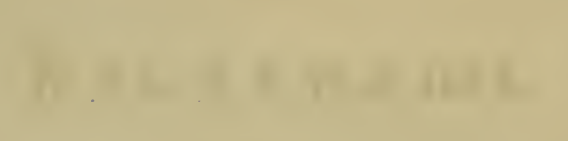




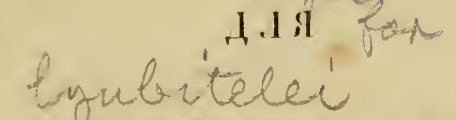

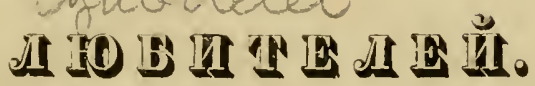
Cores? [rifenesid

C OC: TA IH U I'b II II 3 , A A I

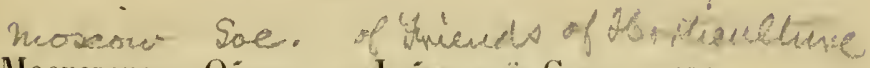

д. Ч. Московекаго Оо́щества Јюо̆птелей Садоводетва

P. $\vartheta$.

II. B. Poinctinoвъ.

ЧАСТЬ ПІЕРВАЯ.

Pit 1

Lisharer

VEW YORK

MI) $\triangle$ Y.CA?

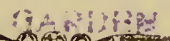

\section{OCK B A.}

Въ ТипографіI Т. Волкова и Кіом.

1857. 


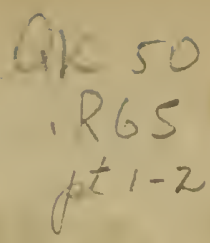

IЕЧATAT, НО3ВО.1ЯЕTСЯ

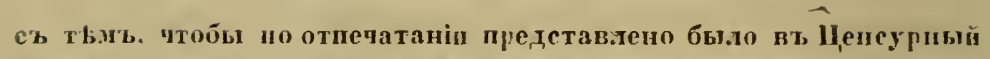
Комитетъ узяконине пис.то экземп.яровъ. Москва, Іюия 22 дня 185 года.

Ценсорв П. Безго.иыкииг. 


\section{P E I II G \& O B I E.}

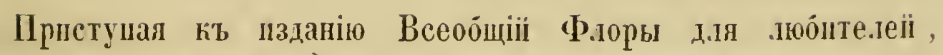
первымъ долгмъ счптаю предъ веъин о.лагодарить тъхъ, ко -

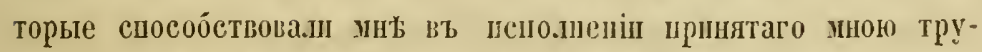
да. Первызъ изъ нихъ былъ Почетиый Членъ пашего ойщества Диштріі Пав.овичь Черкесовъ; посредством его рекомендацін я познакомп.ся съ миогим пзъ ученыхъ п мобште.ей и жіпвое сочуветвіе, которое въ нгхъ встрьтны , много способествова.ло моему ды.лу.

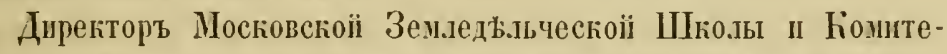
тетовъ Аьсоводства и Агілматизаціп растениї Нпколаї ІІвановичь Анненковъ ойъща.ъ мн‘ достав.ять, что касается до нашей Ф.лоры; гакъ что любите.ль, который оуудетъ получать

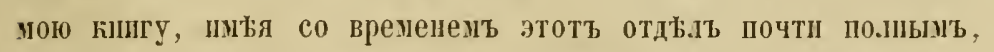
оовязанъ будетъ пе столько миъ, сколько тому, которыі достав.я.лъ мнъ всж пужные дая этого матеріа.ы и рнсунки.

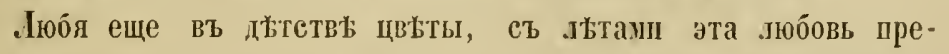

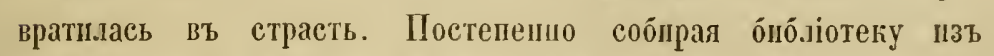
книгт, относящихся къ моему шредету, миъ оыло оольно и досадио впдъть, что только одиа шаша .птература отстала въ эгомь отношенін. Хотя и есть прекрасныя сочшеенія п журналы, но ихъ очень мало, а въ цодобиоомъ родт нътъ вовсе: и это родило во мнъ мысль шрпступть къ тому, что теперь исполияю. 
Зıаю, что на это ма.ло человтческой жизии, но по проложешноіі трошикъ другому легко будетъ ндти, тропнка можетъ сдъ.латься дорогої, а пршьръ важіпъе всего.

Еже.ли нъкоторые пзъ Гг. крптиковъ спросятъ: зачъмъ мое

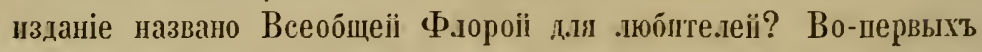
потому, что пзъ слова всеобщей впдн мое желаніе помъщать все, что только относлтся до царства растеніiі. Во-вторыхъ: для любителей; не выдавая сеовя за ученаго ботанпка, прошу Гг. крптиковъ ӧыть снисходгелышым, еже.ли гдъ-ншбудь вгірадутся ошиӧн; а пстиный люб̈птель, впередъ увъренъ, проститъ меня, зиая, что это шшшетъ его же сор̈ратъ, по раздъ.цяемої вмъеть страсти.

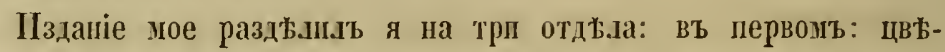
ты, во второмь кустаршин пли деревья и въ третьем' огородиые овощи пли экопомческія растенія плп особенно замњчательыл травы, стараясь помъщать къ каж;дому растенію его рнсуногіъ.

Шо окончапіп нйоторыхъ частеї я б́уду помъщать моп защътки, то-есть: все то, что я встрђчу въ пностранныхъ кнігахъ по.езнаго. Въ заключепіп будутъ прнлагаться шиогда біографін нз́въстныхъ оотаншіовъ въ Евронъ съ пाхъ портретамm. 
(1) I I I A

ІІ Е Р В Ы Й. 



\title{
АНТО.ИЦА ЕОIOICLAЯ.
}

\section{ANTHOLYZA -AETHIOPICA.}

\author{
TRIANDRIE-MONOGYNIE. \\ Семейстьо Касатиковьхъ, Irideae.
}

\section{OEMYIII XAPATETEP.}

Растенія травянистыя; корни волокицтые, шишковатые шли луковнчные; листья въ шизу шрикрываютт другъ друга, а выше походять на сабли и.и мечі, жилки параллельы; цв'ьты на вершинћ стеблей, въ юллосьяхъ или въ зонтичныхъ пистяхъ; цв'Бточный покровъ состоптъ изь двухъ листовндиыхт лопостей, которыя ио большей. части засыхають и походать иа сухую плеву, или пелуху; в'пщикь образованъ изъ шести съобыих сторонъ окрашениыхт лопастей; но иногда наружпыя допасти походять па

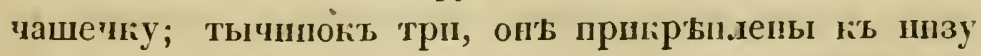
наружныхъ лопастей, пестикт съ тремя рыльцамш: плодь состонть изъ трехраздьлыой и трехгиъздиой коробочк. Растенія әтого семейства распространены въ Европ'ь, С́вверной Амернг'́ и па мыст Доброй Надежды; въ другихт странах' р'вдки. 


\section{РАЗНОВНДНОСТ'.}

ANTHoryu foliis ensiformibus, utrinqué attenuatis, nervosis; floribus spicatis; spicâ oblongâ, distychâ.

Avmowrza Aethiopica. Lin. Spec. 54. - Willd. Spec. 1 p. 222.

GLADroms Aethiopicus, flore coccineo. Corn. Canad. 79. - Moris. Iist. 2. p. 421. s. 4. t. 23. f. 1. - Rudb. Elys. 2. p. 236 . f. 14.

Hxacumpros Afriranus, foliis Colchici, floribus coccineis Pluk. Phyt. 195. f. 2.

Отечество южная Африка.

Въ Европь Антолица появнлась болье двухъ соть льть тому назадъ, и была привезена сь мыса Доброй Надежды, а не из'ь Еөіоніи, какљ бы можно было думать изъ названія дуковпцы.

Сажають въ срединт дыта въ горини въ вересковую землю, и оставляють на воздухе; въ посльднихъ числахъ августа пхт вносять въ теплицу, гды они зацвьтають въ декабры пллі лнварь. Когда по отцв Бты, листья высохнуть, дуковнцы выншмають изъ горшковъ, отдбляют' А'Гок' І сохраняоть, гакт уже отцвытшіе, такт п молодые, въ сухомь мБсть до новий посадгі.

Изъ среднны луковнцы подымается прямой цилипдрнческії стеб́ель, около полуаршина въ вышину; .истья узскіе, кошьсобразиые, острыс, тсмнозеденые, оспованіемь свониь оғружағощіе луковнцу вы два ряда.

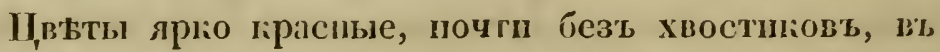
1.лавной тасти стеб.ля, располокеншые панодобіс лалоса. Ка;дый пзт пихь олружсит в', основаніи дву-

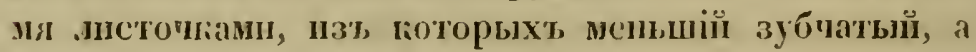


главный раздылент па дв'b заострепныя части. Вынगпк'ь цвТтка однолиствсиный, трубчатый, пе много сгручениы въ основапін, вдругъ увеличнвающіися въ отверстіп однолепестиой трубочки и раздьлениый въ отгио́' па шесть зубчиюов очень перовныхь. Тьчнини, въ тисль трехь, питеобразиы, желтоваты, вс' спрятаны подъ главиымь вънчкомь самаго длшинаго цвътнаго листка, который опћ уравииваюнь в'ь д.лиу. Съмяниая капсулька раздылепа па три части, и содержатьь много сьиянь. 



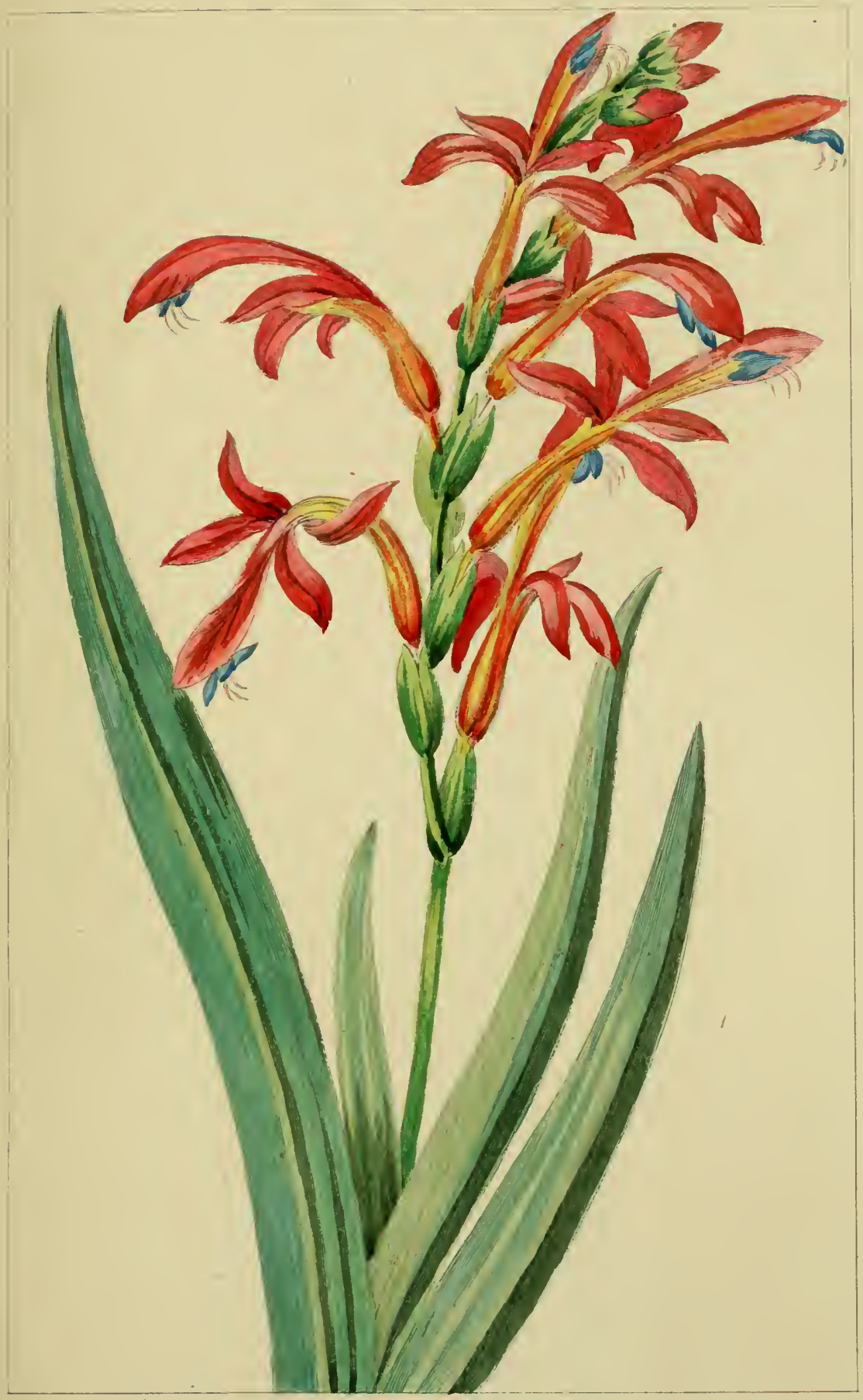

- Hellerelyjore ertleirifievere.

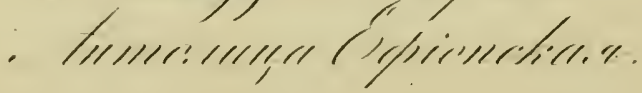





\title{
APICTEА ЦIAHEА.
}

\section{ARISTEA GYANEA.}

\author{
TRIANDRIE-MONOGYNIE.
}

Сенейство Kасатићовьхъ Irideae.

\section{OELIII XAPAKTEPT.}

Spatha 2-valvis. Corolla 1 petala tubo brevi; limbo profundé 6 partito, patulo, subæquali. Stamina 3 Ovarium inferum; stylo simplici, stigmate subtrifido, obtuso, infundibuliformi. Capsula 3-gona, 3-valvis, 3-locularis, polysperma.

\section{РАзиовндНости.}

ARISTEA foliis lineari ensiformibus; caule ancipiti; floribus capitatis; spathis laceris, fimbriato-barbatis.

ARISTEA cyanea Ait. Hort. Kew, ed. 1. p. 67.-Willd Spec. 1. p. 223. - Andrew Bot Repos. t. 10. - Curt. Bot. Mag. n. et t. 458.-Red. Lil. vol. 8. t. 462.

ARtSten eriophora. Pers. Synop. 1. p. 41.

moraca Africana. Thunb Prod. 10. Dissert. de Moraeâ. n. 3.-Mur. Syst. Veget. 93. 
uoraen Aristea. Lam. Illust. n. 494.-Poir Dict. Ene. 4. p. 276 .

xxa Africana. Lin. Spec. 51.

wxiA fobiis ad radicem nervosis gramineis floribus ac fructu convolutis Burm. Af. 191. t. 70. f. 2.

Bermudomana Capensis, eapitulis lanuginosis. Petiv. Sicc. 142.

Granden eriophorum Africanum, fore lanato. Pluk. Mant. 98 .

Отечество мысъ Д. Надежды.

Аиннсй въ описапіп Иксій Іхіа, смьшаль ихт, такъ гакъ въ то время онь былІ мало пзвьстны; но вт посльдствіп очень размножнлись. Тунбергъ. (Thunberg) отдылиль т'b пзъ нихт, въ которыхъ раздьлеиіе в'ћнчна цвттка было правплыю или почти правнльно; ІІ отт әтого изиьненія, Ixia Africana Линиея назғана пмъ Iхіа Могæа. Наконецъ Айтонъ (Aiton) I Вильденовъ (Willdenow), найдя, что опсываемое растеnіе имъеть устье у пестиковт тормой свосй различное отъ другихъ Іхіа Могæа, основалъ новый родъ, давъ ему названіе Аристеа Aristea, которыхъ теперь болье шести сортовъ.

Вт. Еврош' әто растеніе пзв'љстно около восьмидеслти л'вте.

Такъ какъ отпрыски, идущіе отъ корня, очепь часты, то ихъ легко раздълять и әто размиоженіе надо дълать осенью. Еще можию разводить сьмлиамп, которые очень хорошо выспьваютж. Слмена съють въ парникъ илі въ горшк' подь стекляннымъ ко.лпакомт въ легкую землю.

Въ продолженіп зимы содсржуть вь оранжерен; льтомь можно выстав.дть па воздухъ. Жиззь цв'ьтка продолжается только одинь день, онь свертывается къ четыремъ часамъ по полудши и больше не 
открывается. Но какъ отъ корня шдетъ очень много отпрысковъ, изъ которыхъ на каждомъ по нъскольку цв'Бтовъ, разцв'ьтающихъ однит за другимъ постепенно въ продолженіи трехт пли четырехъ недъль мая и іюня мъсяцевъ, то быстрое отцвьтапіе каждаго цв'ьтка отдњльно нисколько не отнимаеть красоты цъ.лаго рістенія.

Корпи состоять пзъ черноватыхъ мелкихъ мочеиъ; отъ нихт идетъ одпиь или нћсколько мечеобразныхъ узкихъ листьсвъ, немного жестковатыхь у краевъ и окружающихъ основаніе.

Изъ каждої середнны купы листьевъ выходить сжатый стебель, пьсколько вытвнстый въ главной своей части и пмњюий листья пушистыя въ основапін. Голубые цвьты соединены отъ трехъ до уетырехъ, па верху стебля и вьтвей; цв'ьточная перепонка состопть изъ двухь копьеобразныхъ темныхъ листочковт пушшстыхт в'ь основанін. Вынчикъ одиолепестный, состоящій изт короткой въ основапіи трубочки І пмъющиї отгибъ глубого раздъленный на шесть почти ровныхъ частей. Тычинки, въ числ'ь трехъ, оканшнватся продолгватой оплодотворяющей головґой, съ двумя сьмянными гшьздамп. Плодъ состопть пз'ь овальной усъчанной капсулI, гдњ съмспа расположены въ трехъ сжатыхъ гнъздахъ.

ARIS'TEA MajoR. Отечество тоже мысв Д. Надежды.

.Іпстья мечеобразиы в' 2 ряда отъ 25 до 36 дюймовъ длины; стебель оть трех' до четырехъ дюймовъ вышины, пурпурокрасный съ прнлистниками; цв'бты распускаются въ іюль длинымь колосомъ, составленимъ изъ стоящихъ гружками голубыхъ ц,вТтковъ. Почва легкая, льтомъ можеть стоять на воздухт, а зимой въ орапжереи. Размножается кагъ Aristea cyanea. 


\section{ОВЪЯСНЕНЕ РИСГНКА.}

Фиг: 1 сверху зародыпъ, превыпаемый поблекпимъ вьнqикомъ, свернутымъ спира.ььо.

2. Капсуля разрьзанная горизонтально съ съмечкомъ съ боку.

3. Нижній вънчикъ завядшій съ одной стороны п тычинки.

4. Зародыпъ, продолговатый стебе.ль и устье у пестика съ подцвътникомъ свойственнымъ каждому цвътку.

5. Продолговатый стебель и устье у пестиковъ въ увеличенномъ впды.

6. Одинъ пзъ подцвђтниковъ и главное перепончатое покрывало.

(cm. Her. Gen. A: 35). 


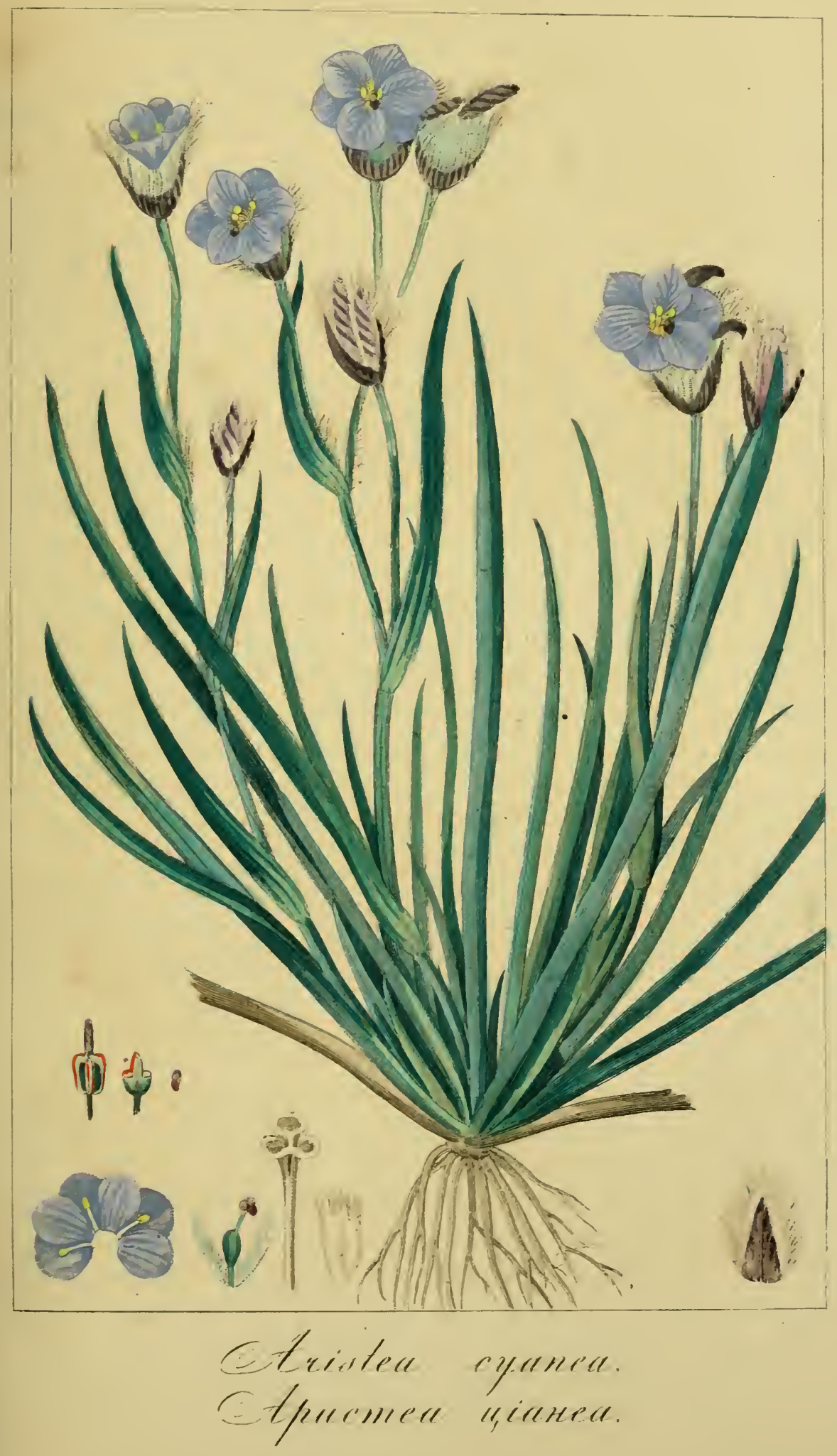





\section{A.JЫIUHIL HУTAHC'b.}

\section{ALPINIA NUTANS.}

MONANDIIE-MONOGYNIE.

Семейство Инбирньхь Zingiberaceae.

\section{OEMLIII XAPAR'TEP'bo}

'Гравянистыя растенія этого семейства растуть преимуществепно в'ь восточной Индін; есть въ Африкт, в'ъ Америк' мало. Корни пишковатые съ мучнистымъ, с.ладкимъ или сильноароматическимь тьломь, они одарепы 'ьдкимь или впзбуждающимъ свойствомъ. Џв'Бты, собранные вь колост или кисть, состоять изь трехъ круговъ. 1, о трехъ лопостяхъ. 2, и.лі средній составлень изъ трехъ равныхъ частей или ст одною иеправилыюю лопостію. 3, большею частію тоже о трехь лоностяхъ, которыя ни что иное, какъ превращценыя тычинки. Настоящих'ь тычинокъ три, изъ которыхт боковыя дв' безпдодны. Завязь трехъ-гизздиая; рылье разширеннее. Дистья въ низу объемлютъ стебель, потомъ съуживаются до

I. I. 
самой пластини, у которой среsній нервњ очень вдавпвшійся, а боковые многочпслены и перпендикулярны къ нему.

\section{РАзновидности.}

AmP1v1A foliis angusto - lanceolatis, glaberrimis; racemis terminalibus, nutantibus lobo medio corollæ maximo, carinato.

AlPivia nutans Roseoe in Linn. Transact. 8. p. 346. Smith. Exot. Bot. 2. p. 93. t. 106.

GLOBBa nutaus. Linn. Mant. 170. - Willd Spec. 1. p. 153. Revouté, Lil. 1. t. 60.

GLOBBA sylvestris major. Rumph. Amboin. 6. p. 140. t. 62.

HENEaLma nutans. Andrew. Reposit. n. et t. 36 ().

Отечество восточная Пндія.

ALPINa NUTANS растеть на опушк' льсовь и у подножія холмовъ. Ея стебли служатт для дъданія тростей на подобіе бапуковыхъ. Высушсниые листья твердыють и Малайцы отправляясь въ дорогу, свертывають ихт въ трубку п кладуть туда вареный рисъ. Въ Европє его воспитываготь около семпдесати пяти льть. Цвытеть весной. Содержится прутлый годь въ тешлицы или въ теплой оранжерев.-Зем.й требуеть легкой дериовой.

Корни этого миоголтнячо растенія шпиговые ползущіе; оть нихъ ндетъ ньсколько прямыхь стебдей, вышина которыхъ па родинь доходпть до 20 футовъ, но у нась бываеть только отъ 4 до 6 футов'ь. Листья узкіе, манцетообризие длиюю оть 15 до 20 дюймовъ, очень гадысі, съужепные въ 
основаніи обхватывающіе стебель; по краямь пушисты. Цвьты состоятъ изъ длшной кисти и каждый из' нихъ пмъетъ сиљсь цв'ьтовъ былаго, ираснаго и оранжеваго, гисть әта до расгрытія цвытовъ висящая, ни потоџъ величествени подымающаяся. Уашечіа цвытка, замьчателыю устроенная, состопть изъ двухт листочковъ, распо.ложенныхт двумя рядамп: парудиый маленькій, обтеилющій в'ь основаній ш мохнатыи, открывается съ богу, раскидываясь въ верху; внутренній трубтатый, вь осповапіи раз. р'ьзань па двое; пзъ нихъ главный шир's, оваьлноогруглень п пушисть в'ь верхуши а маленькій раздълень на двы продолюватых доиост. Џвытиый вънчнк's соединент чашечкой сь внутренимь .истком'ь, 'рубчатымъ въ основанін, раздњленнымъ па три лопости, изъ которыхъ де' биковыя очень велин и изогиуты па подобіе лодочни съ выгиутыми краям; въ низу пестрый, оранжеваго и граспаго

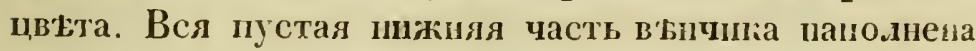
сладимь и клейкимь сокомь, котирый, пепрпитно выстуная, становится густымь, желтоватымь, расноложень в'ь глубпны цв'ттка и полодить иа ко. ренной зуб́ъ. Тычннокъ одна, широкая мочка котирой заглючена въ глубины цв'тка, разширена въ верхией части двумя соедненшыми усьчениыми цилицдрами, образуя деа стмяниыхт пињзда п.лодотворной тытнни. Изљ средичы мединоснаго сосуда выходить иродолговатый питеойразиый стєбель, б'лый, ‘житьй паралдслыный мочкаиъ тычниок, проходяцій между двума сьмяниыми гињздами п.юдотворной тытипіп п пмющій па верху пушистое рыльце ня подоп́іе по.узакрытой чашечи. Находящійся подь вьнчиоми, зародышь колючій, дтлается по словамь Pимтіуса (Rymphius) тройной капсулей, покрытый кльтчатой мясистомакой тканью, которая содер- 
житъ ньсколько черныхь усообразныхь сьмянъ, поғрытыхъ желтоватой иылью.

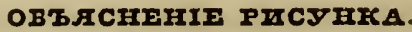

Верхняя часть цвъточной вътви, представленная въ х/з противъ обыкновенной величины. Нижняя часть цвђтка, съ тычвнкой и иродолговатымъ стеблемъ въ настоящую величпну.

(ca. Her. Gen. A: to.) 


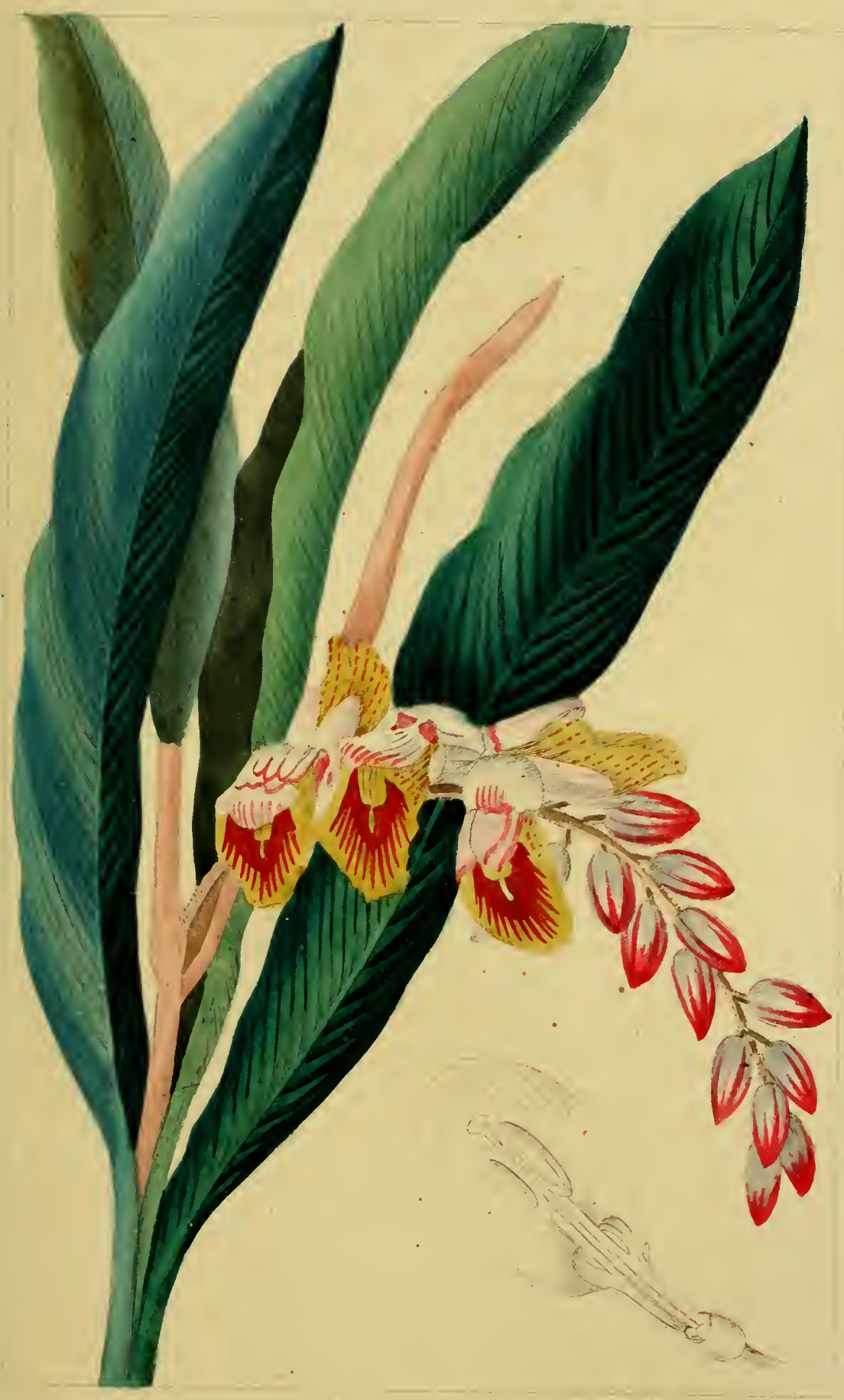

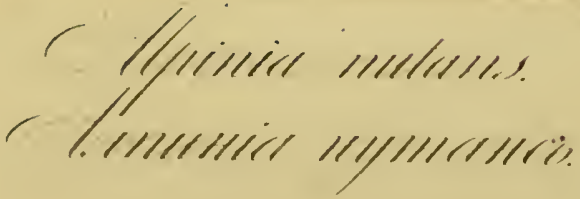


$-\therefore \ldots$

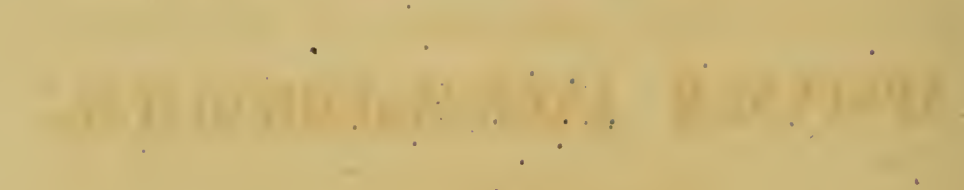




\title{
MYXO.IOB'b.
}

\section{APOCYNUM ANDROSAEMIFOLIUM.}

\author{
PEHTANDRIE-DIGYNIE.
}

Семейство Kурповьхь Apocyneaе.

\section{OKHUЙ XAPANTEPß.}

Расгеніе этого сенейства находится почти во всьхъ странахъ, но иреимущественно въ жаркихь. Листья большею частію противуположны ІІ цвтты б.лаговонны; но почти всь әти растенія ядовптаго свойства, особенно корни. Многія изъ нихъ употребляются въ медпцин. Признаки әтого семейства: чашечка пятираздъльная; вънчикъ такой же, правнльный; тычниокъ пять; столбиюовъ одинъ или два; плодъ различный: коробочка костянка, ягода и т: п:

\section{Разиовидности.}

APOCYNun caule rectiusculo, herbaceo; foliis ovatis glabris; cymis terminalibus lateralibusque; tubo corolæ calycem bis superante. 
APockmum Androsamifolium. Lim. Sp. 311. - Willd. Sp. 1. pag. 1259. Lam Dict. Enc. 1. pag 213. - Curt. Bot. Mag. n. et tab. 280.-Brown. Aselep. 56.-Ait. Hort. Kew. ed. 2. vol. 2 pag. 73.

AROCYNUM. Dad. Mem. pag. 59. tab. 59.

Apocrvour Indicum, foliis Androsæmi majoris, flore Lilii convallium suave-rubentis Tourn Inst. 91 .

apocrumur Canadense, foliis Androsæmi majoris. Boc. Sic. 35 tab. 16. fid. 3 Moris Hist. 8 pag. 609 sect. 15 . tab. 3 fig 16.

По Французски, Apocin Gobe-Mouche.

По Amriĭckir, Tutsan-leared Dog's-bane.

По Hъмецки, Fliegenfangendes Apocynum.

Отечество Сьвериал Америка.

Назвапіе Мухо.ловъ пропзош.ло отт страниаго свойства его цвътовъ Мухп, ирнвлечспныя медовым запахонь сока, который находится вт глубины цв'тохнаго вынтика, опускають туда свой хойотикъ и по м'ры высасысанія пми сока онъ сгунаетея пा онь остантся висяцими па свонхт хоботахъ. Теперь прошло болье ста семпдесяти льть, кагъ әто многольтне растеиіе привезено вт Европу, гдњ его воспитываютъ для уграшепія садов'ь

На земло оно не прихотліво: можно сажать прямо въ групть, но всетаги въ вересковой землы растетъ гораздо лучше. Въ большіе жары надо полпвать часто, а особлиро когда начниастъ цвести. Цв'bтеть въ продолженіи шести недыль п цв'ыты пачннають показываться в' ігль. Размножается осенью раздЕлепісмъ горисй и сьмянамш. Всњ тасти Аросупит содержать молочиый сокь, Бдкій п горькій. Этоть сокт вт большей части растеиій, притадлежащихт кт әтому семейству, пм'ьеть вредное свой- 
ство, и в'ьрно потому родъ этотъ получнль свое имя, которое могло бы имьть этнмологіеї $\alpha$ ло да.льше, и xíwv собака; какъ бы для того, что должно удалять оть него этихт животныхъ, въ избыжаніе вредпаго свойства растенія.

Корень ползущій, оть пего пдеть пьсколько красноватыхъ травяпыхт стеблей 2 тута въ вышину, разд'ьлешыхъ па.противу положныя в'ьтв. Листья протпвуположно овальые, сидящіс па коротенькомь черешкь; въ главной части гладкіе, лоснистье, въ пизу яркозелепье, а сверху бльдиве п чуть чугь пушистые съ краевъ I по жнлкамь. Цв'Бты душшстые розовые пли слегка пурпуровые, расположениые ионьскольку вмьсты малепьним букетамп, сшдяцими па копцахт, в'ттей, и выходлть кромь того изт подъ ослованія верхипхь листьевт.

Каждый цвТтокъ отдБлент и состоитъ: 1 изъ чашечки очень наленькой о пяти разрьзахъ; 2 вьнчика колокольчатаго, о пяти мочкахъ; 3 пяти коротешькихъ тычинокъ, заключениыхъ въ нижпей части вынчнка, пмья плодотворныя тычник соединениыя вмъсть; 4 сқмяна, заключениы въ узеньнит стручкахъ, раздылешыхъ перепопкой надвое, длиною около двухъ дюймовъ II заключающих въ себ' много съмянъ съ пушистыми хохолкамн.

(cx. lier, Gen. No 18.) 


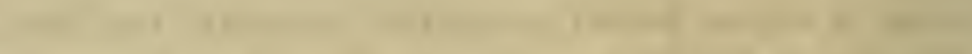
(2) $+100$ th

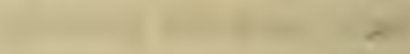
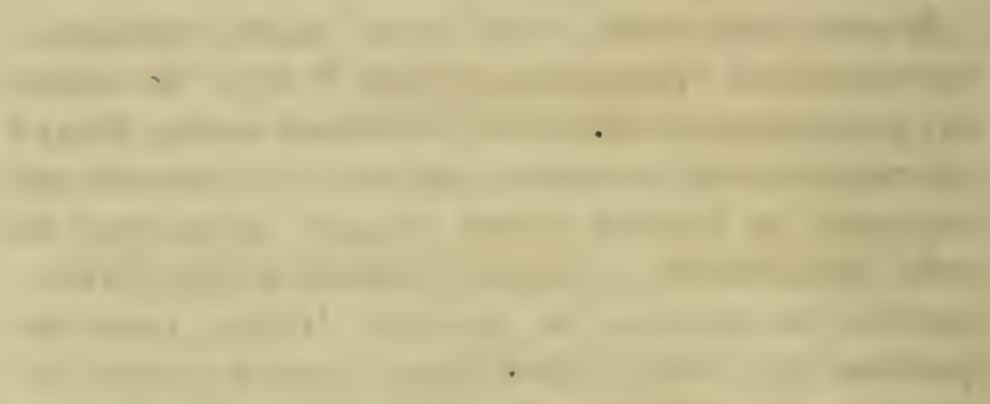

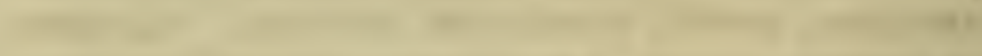

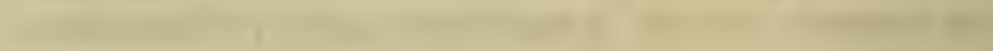

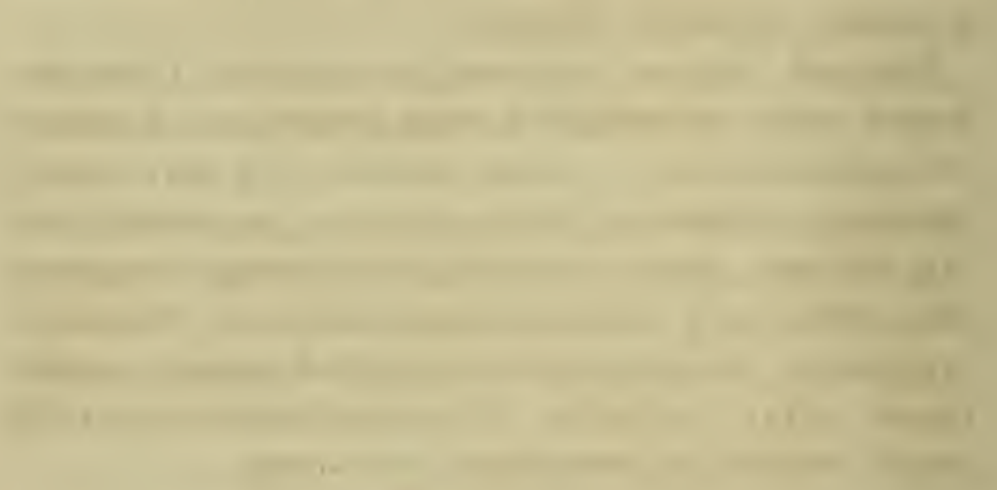




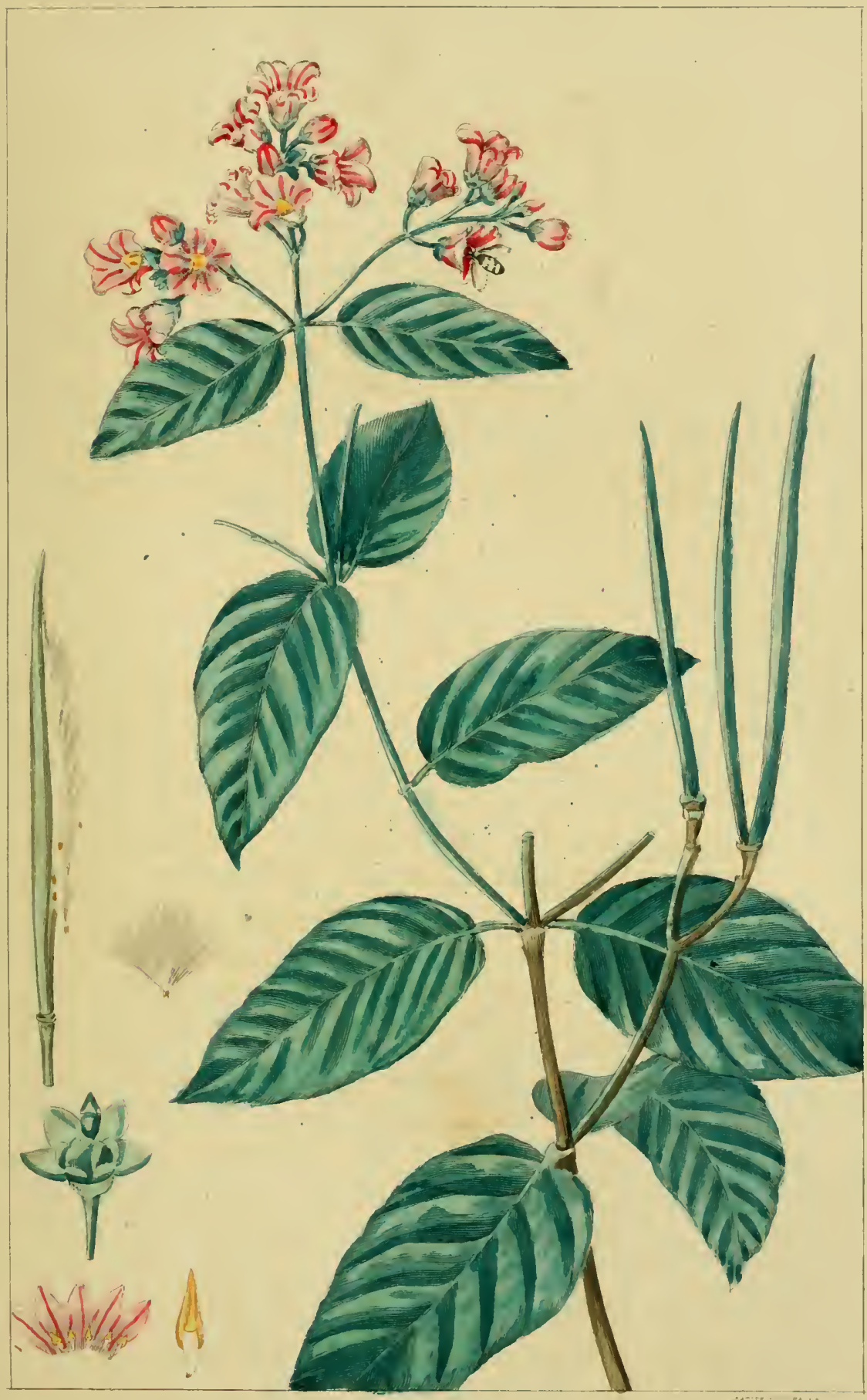

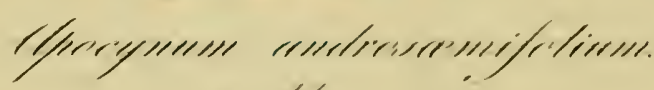

Clyereartis 



\section{AMAPH.IJIICT. AMARYLLIS.}

HEXANDRIE-MONOGYNIE.

Cе.нейстьо Aмарихлисовъихъ Amaryllideae.

\section{OKUIIII XAPARTEP'}

Цвтточный покровъ состонть нзъ шести .епестков', располжженныхт въ двухт кругахт; къ этимь лепесткамь прнкрегляются шесть тычннок; пестикъ сь трехт раздылыымь рыльцемъ. Завязь ниже цвьтнаго покрова по не внутри его. Сьмениое гивздо иохоже .на ягоду или состопть изъ раскрывающейся трехъ-гнъздиой сқмяной коробочки.

Съияна съ мяспстої виутренностью, зарлдышъ у пихь почти прямӧ. Исключая немногія, имьюшия корни иишковатые, почти всь растенія этого семейства дуковнчныя съ узкнми дистьями, въ длину которыхт идуть нервы и.ли жш.й; цвттной стебель б.лзь цвьтовь имьеть прнцвьтини.

Отепество южная Амершка и мысь Д. Надежды; нькоторыя ростуть и въ Европь.

Такь описалп әто семейство Людонт і Нейманъ.

\section{PA3HORLдИOCTI.}

AMArxums rosea, candida, crispa, sarniensis, avrea, vitata, reginæ abrasiliensis. rutilia, obscura, longifolia. Orienta- 
lis, reticulata, curvifolia, broussonnettii, psittacina, longiscapa, moluccana, fulgida, intermedia, leonensis, carnea, slaterniana, meldensis, unguiculata.

(Изъ инсла разновшдностей Амариллиса пе помьшаны много ть, котсрые будутъ помьщаться въ другихт частяхт съ рисунками).

Вообще думаготь что Амарнллшсь должно держать въ теплицт; но опыть показаль, что ихт съ совершепнымъ успьхомь можно воспитывать и въ умьренныхъ оранжер'кях п что этп растенія не такъ чувствительны къ холоду, какъ обыкновенно полагаютъ. Правда, есть иткоторые, напримьръ Amaryllis өquestris, Broussonettii, reticulata, regine, нъжите другихъ; по еслп п пхъ содержать въ теплыхъ мьстахъ умъренной оранжереш, то они такъ же хорошо будутъ рости кағъ и другіе. Содержаніе въ умьрениыхъ оранжерьяхъ предохраняетъ растенія отъ вредныхъ насьиомыхъ и нь тому же, если они и позднье пойдуть въ ростъ, за то будуть сшльные п краспвъе. Не должно выпускать пзъ вида и того, что прп такомъ содержаніп могуть быть выноспмы вм'ьсть съ другпиш растеніями на открытый воздухъ и оставаться тамъ до сентября. Какъ скоро Амарпллисы начинають цвъстш, должно предохранять шхъ отъ зиачптельныхъ измьненій температуры п въ особенности не надо оставлять въ тъхъ мъстахъ, Гды мало теплоты, дучше на это яреня оставдять въ орапжере' на томъ самомъ мБстћ, Гдт стоя.и.

Анариллисы хорошо растутъ въ чпстой вересковой почвь; но лучше всего въ смъси $1 / 3$ вересковой, y $/ 3$ перегишшаго листоваго павоза и $1 / 3$ рычнаго песку. Такая смњсь особенно хороша для тьхъ луковпцъ, которыя сажаются въ горшін; но для высажшваніл въ открытый грунтъ очень хороша сльдугшая смьсь: х лпствениой и $1 / 2$ річнаго песку. Еслп дуковнцы 
садять въ чнстый рвчной песокъ, то хорошо сверху пригрыть ихъ мхомъ, потому что чрезъ әто будеть держкітыся в'ь песк'́ в.ланность.

Два раза въ году ростять Амариллисы: первый разт, ежели держать ихь въ умьрениой оранжерет, съ янеаря до мая; второй - оть августа дп огтябоя и даже поздные. Нъготорые изъ пихъ во время покоя теряютъ свон листья, - и въ әту пору обыкповенно пересажнвають ихъ. Если пересадка дьлается изъ малаго горшка въ большой, то әто дБлается обыкновениымь образомъ; но если луковицы, пьсколько разь пересаженныя, имьоть вокругь себя твердый и негодиый грунть земли, съ которымь пересаживать очень вредно; вт такомь случат поступаютъ сльдующимъ образомь. Въ іюшь когда луковщцы отцвЈтуть, ихъ вынимать нзт земли отрбзываюють корни на ньсколько дюймовъ п потомь сажають. Молодыя луковицы, которыя еще пе давали цв Бта, сажають вт конц' сентября, но пе поливать шхъ тотчасъ по посадк', а тогда какъ он' начнутъ проростать и то по немногу.

Ежели можно садить луковицы вт умьренную оранжерею и въ парншковой грядк' вт грунть и здћсь оставлять ихъ, то әто ешце лучше. .Ауковшцы Въ горшкахъ разцв'ттаютъ преждевременно.

Очепь хорошо оставлять луковицы на поверхности земли (въ горшкахъ) безъ покрыши, а не сажать шхъ на пзвъстную глубпу. Такь он' лучше сохраияется оть гнилости, корип займуть все пространство горшка, и впосльдствіи легче безт повреждепія луковнць ставнть подпорку и луковица будетъ пользоваться вліяніемь огружающаго ее теплаго воздуха. Не худо замьтить, что надо остав.дть на дуковпцахъ засохшую чешую, потому что она служить защитой отъ вредиых прпчииъ. 
Особенно должно паблюдать, чтобы поливка луковицъ, посаженныхъ въ горшкахъ происходила соотв'Бтственио ихь природь. Когда он'в растуть и цв'ьтутъ, ихъ поливаютъ достаточно и при этой полшвк'Б наблюдать, чтоб́ы вся вода стекала; но во время покоя ихъ каюъ можно менъе поливают'ъ, чтобы только корни были свьжи; если же ихъ довести до сухости, то луковшцы не дадуть цв'ьта.

Еслі все әто дълалось, и между тым' ныкоторые изъ луковиць не ироростають, должно вынуть ихъ. Ес.лі прн этомъ увидять, что корні въ худоме состояніи и можеть быть частію загинли, то ихъ очншають, раскладывають на земль II просушиваютъ. Но если видятъ, что корши пусти.ли новые корешки, то такіе лукиццы садять въ маленькіе горшки, мо зем.лею не засыпають, а только пзрьдко ио.ливаютъ посль' чего въ скоромъ времени корни разростутся и луковица спасена.

Если бы у такой луковицы и сердечко заниило и уже нельзя никагъ помочь ей; то всетаки не должно пренебрегать ею; потому что здоровыя ея части могуть дать покрайней мьрь боковыя луковнцы.

Такъ какъ Амарндлисы боковыхь луковицъ производять не много, то приходитея размножать ихъ съмянами. Но съ другой сторошы, если эти растепія оставнть самихъ по себь, то оны рыдко дають сьмлна; поэтому надо приб́ьгать гъ искусственному опдодотворенію, отъ котораго, кромь сьмянъ, можно еще получить новыя разности У игру въ цвътахъ.

Способъ искусственнаго оплодотворенія очень прость: на рыльць пестика переносится пыль шли пзъ того цв'ьтка или изъ другаго; въ посльднемъ случағ въ оплодотворяемомъ цвьть должны быть сняты всь тычпнки до раскрытія ихъ пыльншковъ. 
Вообще при искусственномъ оплодотвореніи надобно помнить слЂдующія предосторожности: 1) пыль переносить въ полное развитіе рыльца, и когда па немъ замьчается липкая жидкость; 2) ть растенія, которыя назначаются для искусственаго образованія разностей, а равно и тБ, съ которыхт берется пыль, должны стоять отдБльно и другъ оть друга и отъ другихъ подобиыхъ растеній, и по возиожности должны быть защищены отъ наськомыхъ, легко переносящихт цвьточную пыль ст одного цвьтка на другой; 3) оп.лодотвореніе удачнъе совершится вт сухую и не вттреную погоду, сльдователын въ такую пору и надобно пронзводнть его.

Если съмяна поспьють, то коробочки, содержащія ихъ, лопаются. Собравши съмяна, разсыпають ихъ на ньсколько дией на открытомь воздух'ь, гд'ь они просохнутт, по просушкљ ихт тотчаст же и съятъ. Сћютъ ихъ обыкновенно въ широкихъ горшкахт вт вересковую почву, слегка прпкрываютъ тою же землею и умьренно поливаютъ. Посль этого ставять горшокъ въ парниковую грядку и каждый день поливаютъ такъ, чтобы земля постоянни была влажная, но при этомь наблюдать, чтобы поверхность не затвердъла какт гора. Какъ скоро стмяна натинають всходить, то всходу ихъ помогають легкшиъ разрыхленіемт земли и полпвкой. По совершенномь всходь сьмянт, ставять горшки какъ можно ближе къ окнамъ и каждый день впускать свтжій воздухъ и затьнять их'. Осенью горшки ставятъ въ грунтовой сарай или въ ирохладную оранжерею, вт самое хо.одное мьсто, для того, чтобы пріостановнть растительность; въ это время поливають ихъ очеиь мало, только чтобы не совсьмь посохли листья.

Весної, въ концт марта, молодыя дуковнцы высаживаютъ въ открытый грунть, въ почву, соста- 
в.хенуго изъ лиственной п песку по ривной части; корней при әтой посадкт не подрқзываютъ. По посадкв всго грядку прикрываютъ парниковымп рамами, до тыхъ поръ держаты пхъ такт, пока нечего опасаться морозовъ. Здысь молодые Амариллисы остав.ляотт въ продолженіи льта и зшмы; веспюю пересаживають ихъ вь горшки и ухаживають какт за взрослымп. Обыновенпо луковицы оть сьмянь цвътуть на четвертый годъ.

amaryens rosen. Отечество Гаваниа.

Луковицы маленькія, коричневыя; листья стоящіл близь другъ друга; въ августь и сентябрt сбоку выростаеть цвьточная стрьлка оть 6-до 10 дюймовъ вышины, п на вершинь ея распускается одинъ очень краспвый темнорозовый цвттокъ, Содержаніе подъ стеклами. Въ коро.евскомъ Парпжскомь саду есть разность сь большимп темнорозовымп цвттами.

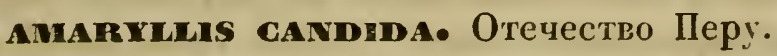

Луковицы огруг.леныя красновато-корнчневыя ; листья прямостоящіе оть $3 \frac{\pi}{2}$ до 6 дюймовт длины; цв'ьточная стр'яға такой же длины; в' октярь на нсй распускается одинъ цв'токь, у котораго три внутренне лепестка чисто былые, а три ндружиые иа концахъ розовые. Легко сохраняется на открытомь воздухक.

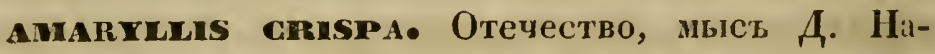
дежды.

Луговпџы овальыя; врасныя листья линевые желобкомъ; вт сеитябры пли огтябр' распускаютея пурпурово-розивые цвъты безъ занаха ленесткі пх'ь загпуты назадт и немиого волипсты. Сажають в'ь горшок'ь в' вересковую землю и слегка поливають; зимой подт стекламп. Размножаются боковыми луговпцами. 


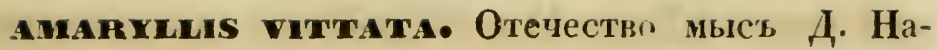
дежды.

Содержптся вт болыших горшкахь, зимой в́ь оранжерет пли в'ь грунту, но подт стекламп, или вблпзп стьны, подъ покрышей па зиму, въ пестаной теп.лй почвь. Листья длпниюе, узкіе, съ граспотой, цвьточная стрь.лка 25 дюйновъ вышины: въ Іюнt: развертываются четыре пли иять ғрасивыхъ большихъ, горизопталыых цвттковъ, у которых трубіа д.пнная, зеленоватая красно-разрнсованная, сь запахомъ черной смородины; городки съ зарубкаши, чпсто бтлые внутрениіе сь 3 темнокрасными полосками. Размножается боғовыму луковнцами и сtмянами.

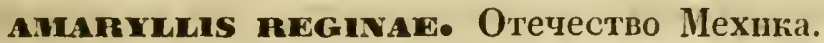

Луковицы зе.леноты листья похожи на ланцеть лддычко̆; цвБгочная стрь.ла 20 дюймов'ь вышины па ней выростаетъ оть 5 до 5 больихх расходящпхея, юолоко.ичатыхъ цвытка у которыхъ трубка коротка а устье во.іосисто, городки пунцовокрасные, книзу зеленоватые къ устью съ бахрамой; выртзюи слегка волинтые.

Цвытетъ зимй пли въ началғ весны. Содержаль пх' въ теплпць въ горошкахъ или въ грунту въ почвЫ садовой смыпанной с'ь вересковой. Разиножается боковыми луковнцами, которыя выростаютъ pъдrio.

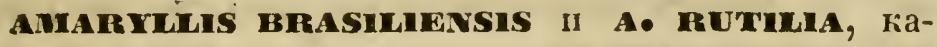
жется, ни что пное какъ разности A reginae. Воздылывають ихъ одинаківо.

Amartums obscura. Луковицы средней ве.п.ичины; листьевъ четыре равныхъ, ньсколько овалыныхъ и полосатыхъ, зеленыхъ, вт средшнь съ бт.1ова- 
той по.1оской , отъ 14 до 16 дюймовь длпны; цв ЂТная стрєлка сърозеленая 18 дюймовъ вышины съ декабря и до февра.ля выростаеть 4 и 5 темнопурпуровыхъ цвњтковь содержится въ теплиц плли въ грунту.

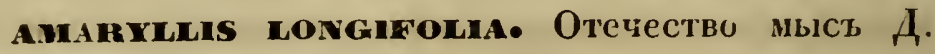
Надежды.

Луковпцы очень длинныя, листья широкія, желобкомъ, отходящіе, изогпутые, до 25 дюймовъ длины; цвьточная стрБлка сдавленная вт, 2 дюйма вышины; въ іюны или іюль развертывается миожество цв'ьтовъ собранныхъ въ зонтнкт бьлыхъ, съ яркокрасиыми полосками по средины лепестковъ. Сажаютт луковицы вт открытый грунтъ вадолго до наступленія зимы и прикрывагть, пли въ оранжерею гд'ь цвътутъ в'ьрнъе.

amarichis onientanis, Отечество Индія.

Луковпцы очень большія; цвьтная стрьлка кровяно-красная 12 доймовь длины въ октябрь и иоябр'ь распускаются многочис.ленные красиые цв'Бтки, образующіе видь паникадила; посл'ь цвъта выростають два или три листка похожихъ на языкъ. Содержатся въ умьренной оранжереь, потому что в’ьрнъе цвътетъ.

amarmuls methedrata, Отечествo Бразилія.

Листья длинноватые къ низу поуже, съ красивой бъ.юй срединной жи.юкой; цвтточная стрьлка сдавленная; въ Апрьль расиускается два или три фіолетовыхъ, темносытчатыхъ цвътка. Содержится въ теплиць. Размножается боковыми луковицами. Аегкій чериоземь смьшаныы съ пескомь.

atinguls cuntifolia. Отечество мысь $A$. Надсж,ды. 
Луковицы пирамидальныя; листья линеобразные, иьсколько похожіе на серпь, строзелепые; цв'ьтна стрьда 5 фута вышины, четырехь-угольиая, зонтикь составляется пзь 8 или 12 больших блестящекрасиыхт, безғ запаха цвьтовъ съ волнистыми, закручепиыми городками; тычннки прямыя, высовываюпцяся пзъ цвътка. ІДв'Втеть въ іюль.

AMARYLLIS BROUSSONNETTH. Листья длIHHOватые, очень узкіе, слекка волинстые; в'ь іюнt распускается 1 нли 4 цвттка, бълыхь кағъ молоко, сь яркокрасной широгой полоской, посредин'ь каждой лопости. Седержится вт теплиц'ь в' легкой почвъ. Размножается боковыми луковицами.

avareme psitwaciana, Отечество Бразилія.

Листья ланцетомь, сьрозеленые 15 и 18 діоймовъ длиы, цвттная стрылка высокая и гибкая, покровъ розовый, въ іюль и августь распускаются два цвьт:а величиной съ бєлую Лилію; ноготки у них'ь зеленые съ пурпуровыми полосками, а отгибы до половниы городковъ бълые съ спльо красыым чертичками. Сидержится такъ же какь II другіе.

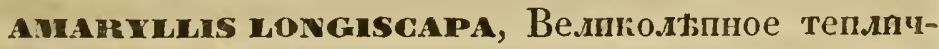
ное растеніе; на его цвьтной стрълкь достигающей оть 36 до 48 дюймовъ вышины, бываеть 4 нли 6 шатрапокрасныхь, пунцовыхъ въ 5 дюймовъ д.лины ци'ьтков'ь и требјеть ньжной и питательой 3evi.nII.

amateyens moeuccana. Луговпцы большія, овальныя; листья оть 3 до 4 Футовъ д.лиы, с'ь жестими какь хрящъ краями, а книзу слегка волинтые; цвьточнал стрьлка очень сжатая, выходящая изъ .истьевъ оть 14 до 20 дгойовъ

I. I. 
вьпшинь п поситъ до 12 болыппхъ, сидящихъ, очснь похожихъ иа колокольтикъ съ попостямп; въ средшн' съ пурпуровнми полосками, цветки. Цвьтеть в' тен.ицц въ іюн' и ію.1ь.

amaryeus FULgida, Отечество Бразилія.

Луковицы толстыя округленыя отъ 2 x/2 до 3\% а дюймовъ въ поперечникь; онъ пускаютъ то.лько два листа, которые внпзу передними боками соеднняются, длийй бывають оть 10 до 14 дюймовъ п похожи на языкъ. Отъ самыхъ лпстьев'ь возвышается до 25 дюймовъ, то.лще большаго па.льца цвьтная стрьлка, оканчивающая Р: двухт-лпстовой цв'ьтной потровъ, пзъ которэго появляется 4, почти до 4 дюймовъ ширипы, кпноваре-красныхъ цвттка; труена цвттовъ сиаружи зеленая, но виутри желтовато былая. Тычинги и пестићъ шатрапножелтые и въ половниу длипы вынчпка; три нити рылыца длинныя и пазадт заяруглеиныя. Содержится въ теллиць.

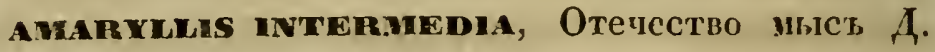
Надежды.

Ауковицы похожи иа грушу, средней то.ицины, норичиеваго цв'ьта; изъ ипхъ выходить 4 и.ли 5 линіевпдныхъ $2 \frac{r}{2}$ и $5^{2} / 2$ дюйиа длины листьевъ. Въ яиварт; и февраль выходпть оть 3 до 6 дюоймов'ь вышшиы цвьточиая стры.иіа, на ней выростаетъ трп или четыре цаттка о 6 горпдкахь, изъ которыхъ три силыокрасные, а другіе три свытлограснье. Содсржится въ теп.лиц.

amanxuls heonensis. Лукорицы груг.10-продолюватыя, сиаружи териоватыя два или три .иега узкпхъ, сиизу лодочюо̆, џвЈтная стрьлка пустая, қак'ь бы писемт покрытая, съ двумя очень болын-

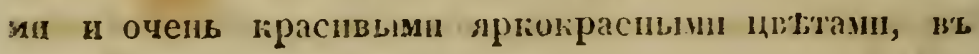


средин с съ большимъ, похожимъ на зв'ъзду пятныикомъ, а по краямъ съ бахрамой.

amarmels cannea. Это растеніе очень замьчательн. Если держать ихъ па полкахъ в' теплиць, то оно будеть цвєсти и давать сььмяна два раза E'b ГOдъ.

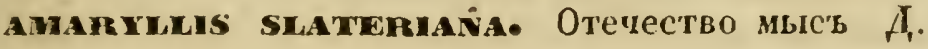
Надежды.

Џвтты иаленькіе, но очень граспвые.

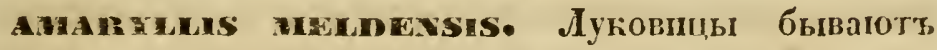
оть 14. до 16 дюймов' вт огрунности; Апстил в' 5. футовъ длны п до 4 дюймовт ширниы; цв'Ттная стрылка больпая и ирлмая, цв'вты во мпожеств' бњлосньжиые, котирые держатся дней 30 ; чашечка сиизу розовокрасная; занахъ очеиь благовонный. Большія луковпцы обыкиовенио пускають трп стры.и. Содержатся вт умтрениой орапжерев и.ии грунтовом' сарат.

Размножается боковыми луковками, поторыл бывзютъ многочис.лены.

Amare yels ung Uncunata. Отетество Бразиян.

Уходъ за әтимь Амариллисомъ кагъ и за другими; оиь не так'ь красив'ғ; зеленые цвьтки его выходять

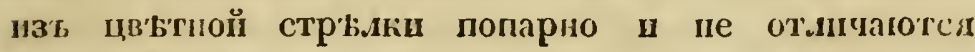
излщиой отдьльой.

Уходъ за Амарилыисами взятъ изъ описанія Еме́ 'Tiop.ropr, (Aime Turlure), который въ Версал'b почти иск.иопте.льио запималя воспитаніемь ихъ.

(cx. C.x. Ces. Xo3. Poct. cr. 59, Le bon jazd. a Nexw. Gar-Jahz.) 


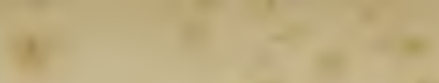

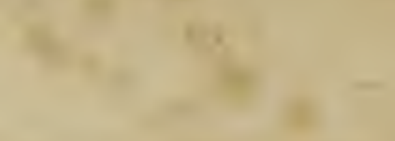

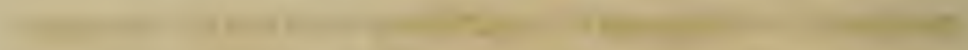

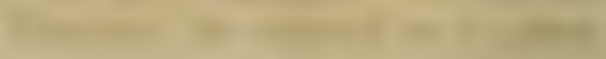

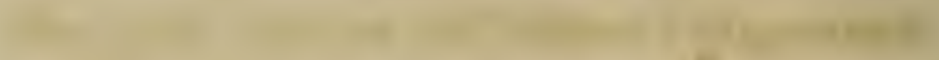

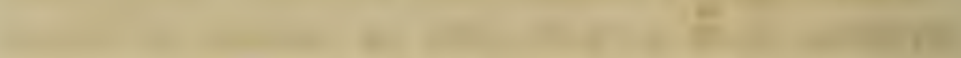

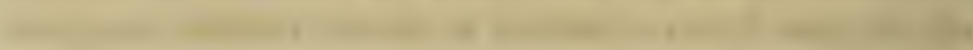
, $10-2$

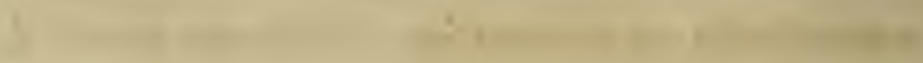
(14)

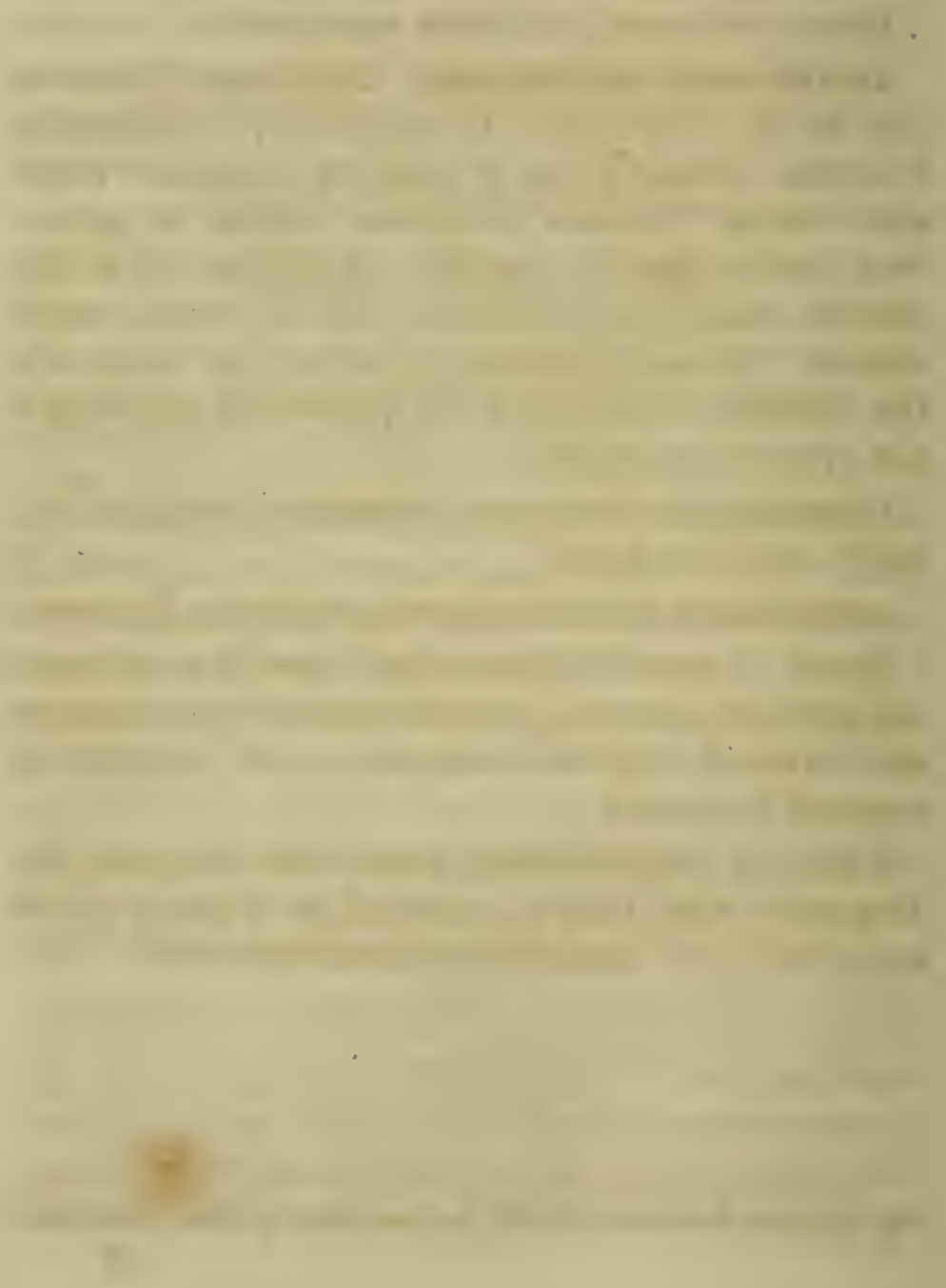

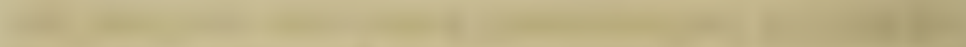
(2) (1) 


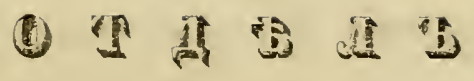

D T OPO 



\section{APUCTOTE.II MAKBH.}

\section{ARISTOTELIA MACQUI.}

DODÉCANDRIE-MIONOGYNIE.

Семейство Площановьхх Hотаlineaе.

OEMLIII XAPATETEPGo

Очень малочисленное семейство, состоящее изь тропических деревцевъ или ліустарниковъ съ иеопадающшми листьям. Чашечка раздылена оть 10 до 30 лопостей, пзъ готорыхъ внутрениія иредставдяють вьнчикъ. 'Тычинок' тоже оть 10 д) 30 иногда бываетъ и болье. Пестиковъ оть 3 ди 5.

Плодт состопть изь коробочки или ягоды.

\section{РАзиовидности.}

Arestorena foliis oppositis, ovato-lanceolatis, serratis; floribus subracemosis, axillaribus.

Arestotema Macqui. L'Herit. Stirp. 1. p. 31. t. 16 -Willd. Arb. 27. -Willd. Spec 2. p, 851.-Lam. Illust. t. 399.-Poir. Diet. Enc. Suppl, 3. p. 587.

Anistotema glandulosa. Syst. Veget. Ftor. Perur. p. 126. 
Ep!тье (L'Héritier) посвятиль ато деревчо памяти, зиауснитаго философа древности Арпстотеля.

Лервоначалыое мьсто рожденія растенія носящее таное громкое пмя Хили, откуда оно вывезено было въ Европу болье девяюоста лытъ тому назадъ.

Сажаготь его въ гориіокт плII кадкіу въ легкую землю, льтомь выставляють на воздухь, осень у иась виослть въ оранкерего; но въ южнй тасти Европы можеть зимовать па воздух' подт погрышкой. Размиожается сьмянами, отводками и черенками. Цвьты показываются въ апрвль і мађ. На родннъ, Плоды бываютъ величнио̆ сь мслюуго вишию; употребляются въ ппщу. Туземцы приготовляють изь пихъ прохладительне питье, такь же посредствомъ брожеиія дълають что-то въ роды ликера.

Аристотелія вт нашихъ оранкереяхь выростаеть оть 5 до 6 жуть въ вышшн; стебель нћсколько грасповатый имьеть такіе же, противуположшые вьтви, сь листьями тоже противуположиымн, продолговатымг нли овальіо-копьебразиыми, зазуі рельнымі; верхияя часть листа гладкая лркозелешіго цвъта; пижляя бльднье и съ легка пушиста. Џв'ыты маленькіе, былые, большею частію по три пмқсть спдящіе на обцей цвьтнй нижк' и пеправильн расположенные кистями на копцахт вътвей и изь подъ плечикивъ листьев'ъ,

Нижняя часть цвытка одиолиствениа, глубоко раздћлена на пать тупыхъ разрқзовъ, пушистыхт, бо-

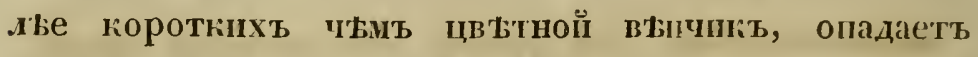
прежде другихт частей растенія. Цвыточиыхь лепестковъ пять, оши овальны и расположешы подь тычпиками, вогругь особеппаго кружочка о иень топкаго, который запимаеть пшжиою тасть цвђтка.

Тычннки около пятнадцати имыють мочкі короче вьичика, расположешы на пружечк' и оганчиваются 
продолговатыми головками плодотворныхъ тычннокъ, сг двумя с'ьмяными гиъздамм и каждое изъ нихъ открывается съ крағо пебольшой дырочкой. Зародышь находится на середпнь кружка, шарообразень, имъя съ верху выходящій изъ средины продолговатый стебель обыновенный въ низу а въ верху раздъленный на трое, длшиње другихь частей цв'ьтка и оканчивающйся тремя согпутыми рыльцами. Плодъ состопть изъ ягодъ, въ началь прасныхъ, пю м'рь же поспьванія прншмающих и черноватый цв ьтъ; величнною у нась доходить до крупной черной смародниы, съ прозрачными точкамн; внутри имњеть тріг сымяниыхь тивзда; каждое пзь пихь заключаеть двй нли три выпуклыхъ угловатых' зєрна.

\section{ОВЪЯСНЕНIE РПСУНКА 5.}

1. Цвъточный лепестокъ въ настоящую величину.

2. Чашечка цввтка въ увеличенномъ видъ.

3. Тычинки увеличены.

4. Зародышъ, продолговатый стебель и рыльце у пестиковъ увеличеио.

5. ІІлодъ разрьзанный горизонтально съ тремя сьмянными гньздами.

(cm. Her. Geu. He 66.) 



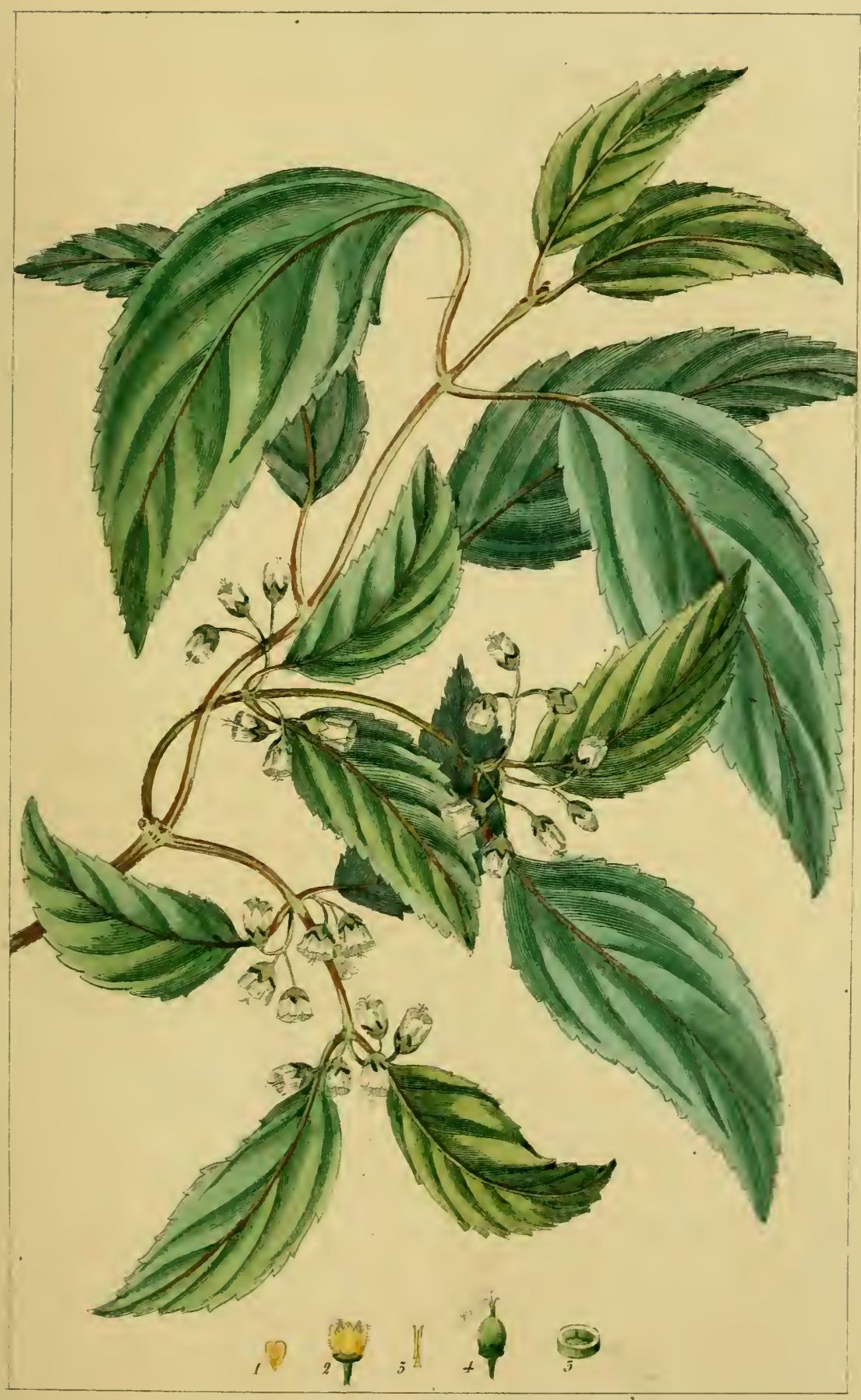

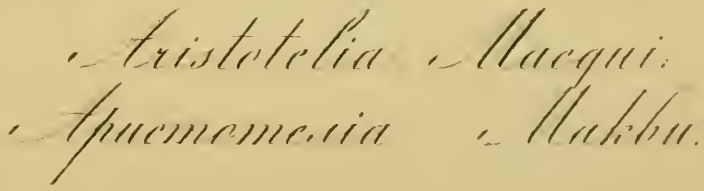




\section{.}

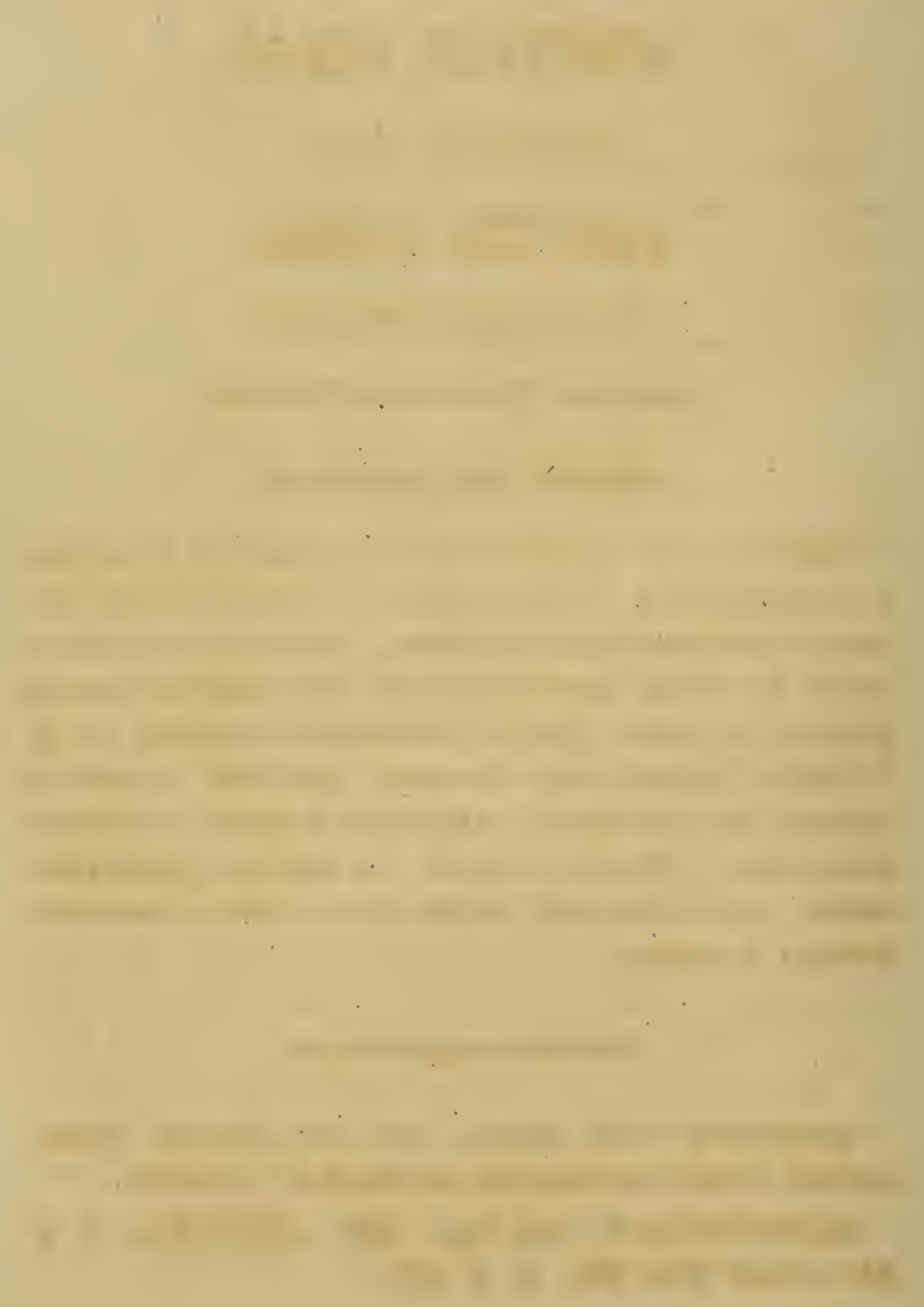




\title{
АРБУТУСТ УНЕДО.
}

(Зенлянииное дерево.)

\section{ARBUTUS UNEDO.}

\author{
DÉCANDRIE-MONOGYNIE.
}

Сежейстьо Вересковъгхъ Ericinеае.

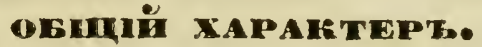

Семейство әто состоить изъ маленьких деревцовъ п кустарниковъ съ лшстьями противуположными или расположенными въ кружкахъ. Оно расиространєно иочти во всьхъ странахъ св'Бт, но самые красивые растуть иа мысы Добрий Надежды. Џашечка съ 3, 4 घли 5 городками, вънчикъ ц'Вльный п имьетъ столько же лопостей; тычинокъ сколько лопостей или вдвое; столбикъ одинъ съ одним рыльцемъ; ПАОдъ состопть изъ коробочки; сьмяна многочвсдешны и медка.

\section{PAJHOBEAEUCTE.}

AnBurves caule arboreo; foliis ovato-oblongis, glabris, serratis; racemis subraniculatis, terminalibus, nutantibus.

ARBdTts unedo. Linn Spec. 566. - Willd Spec. 2. . 617. -Lam. Dict. Enc. 1. p. 225. 
AnBuTUs. Matth. Vatgr. 270.-Cam. Epit 168.-Dod. Pemp. 884.-Lob. Ic. 2. p. 141.

Aremutrus folio serrato. Bauh. Pin 460.-Tourn. Inst. 598.

Отечество мысъ Аоброй Надежды.

Арбутусь у нась на сыверь растет: деревцемъ не больв 8 футь в'ь вышину; но въ гжныхт страпахъ, образуеть дерево до 20 рутивт. Обыниовено воспитывають его въ горшкахъ или кадкахъ, давая .сгуую терпозсмпую почв: льтомь выставлясть па воздухь, на зиму вносять вт оранжерег, держа ближе кь св'ьту. Размиожають отводками и сьмянами, у насъ рыдыс созрьвающими. Цвътеть съ августа но октябрь, п.ходы созрьвають чрезъ тодт; ой имьютъ терпкій вязущій вкусъ.

Изъ опытовъ, сдылапыхъ, хпмикамі, впдно, тто изъ соку пьода можно дылать сахарь. Посредствомъ броженія дТлають впно и уксусъ; а дистилируя можно подучить водку.

Арббутусъ имъетъ темпо-красный стебель слегка пушистый съ разсьянными по пемь жилами, украшень продолговатыми пеопданищнми гладкини досияпимися листьями, темно-зеленаго цвтТа, не ровно зазубреиными сидящими иа короткихъ стебелькахъ. Цвтты былые или слегка грасповатые, расположеннье по.дсклопеной кистью. Нижнял часть цвътк коротка, однолиствениа и глубого разд'ъена на пять округлепиых частей. Втичик тоже однолиственный разрызапъ въ устьћ па пять короткихь тупыхь зубчиковъ закругленыхъ паружу. Тычники вь числь десяти пмьеть мочки вт половпну короче втІчика, коппческіе п всь покрыты волоскамп. Каждая мочка окапнвается головкой плодотворной тычнни, почти овалыой, чмыоцсй два сымяныхт гиьзда, 
отюрывающихся вь верху овальной дырочиой. Зародышт почти шарообразный сидящій на мясистомт кружк'. Плодь состонть нзъ красной ягоды, похожей иа зем.линиу, виутренно раздылспий иа иять

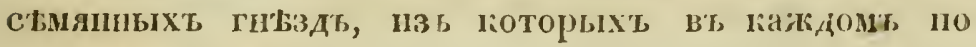
птеко.ику зерент.

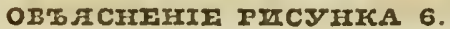

1. Џвъточная ножка, чашечка и пестик'

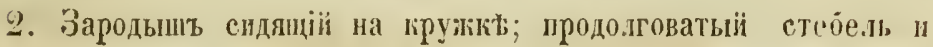
уетье пестиiл.

3. Тычинка.

4. Ягода въ настоящемъ виды. 
the

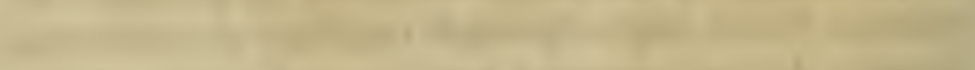

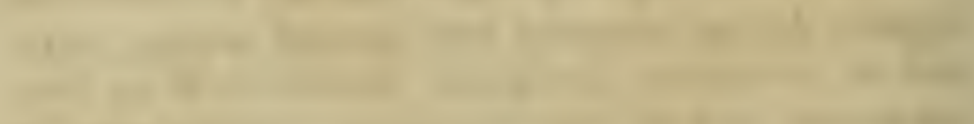

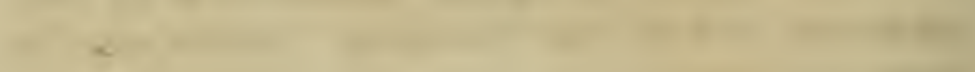
(n)
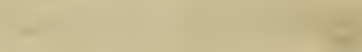

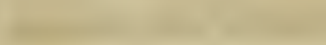

1.

I

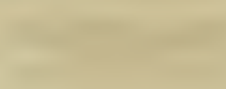

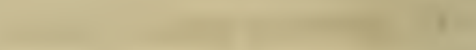
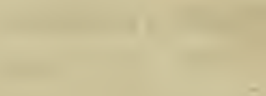

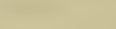

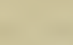

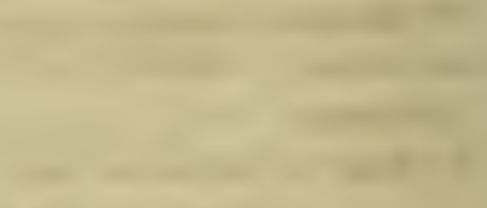

$=$

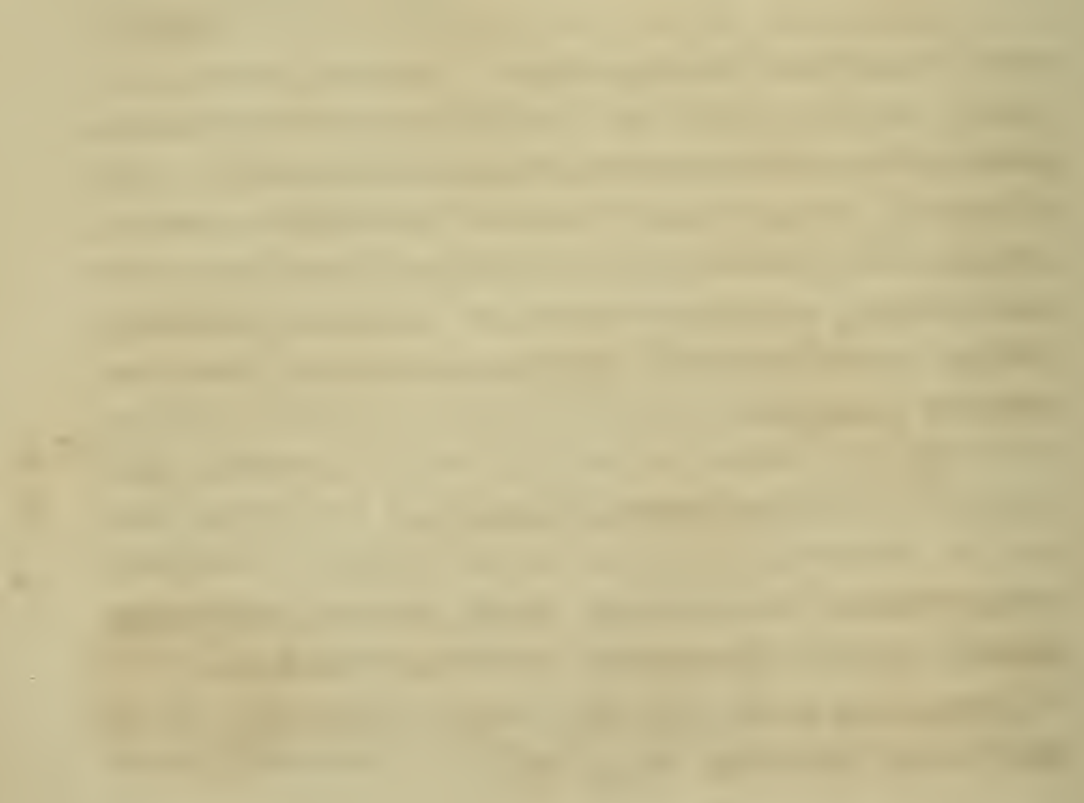



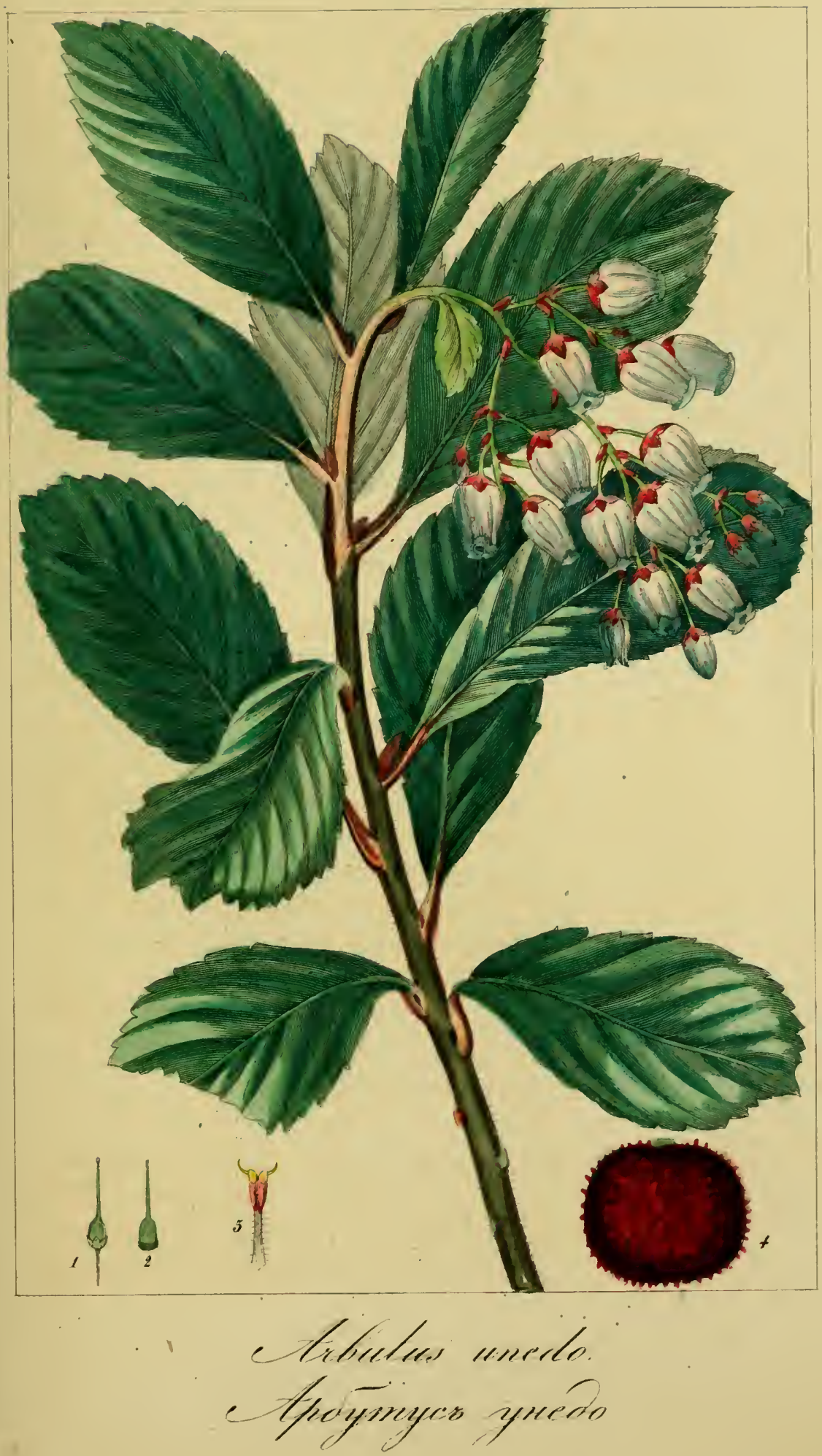



\section{АКАЦИ АЕЦИІІЕНСЬ.}

\section{AGAGIA DEGIPIRNS.}

POLYGAMIE-MONALCIE.

Cенейство Бобовыхъ, Leguminosae.

\section{OSHüLi: XAPAKTEPT.}

Әто семейство рызіо от.бичастся оть других

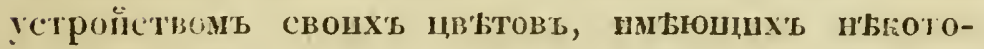
рое сходство сь матылыомь. Уашечка обынновено

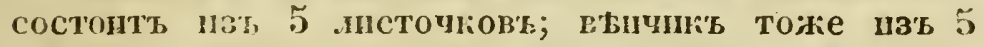
.епестіов; тисииок бываеть вдвое втрое и вчетверо бо.ье иротив лепестков вынчика, и нити ихь сросиіяея вь ивсколько пучиовь; пестикь одиъ; ('ыминое гиьздо тоже одио, но пногда бываеть огъ 2 до 5. Это семійство состонть изт растеній тра-

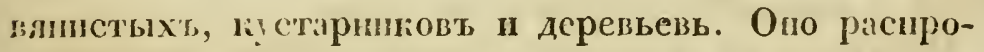
странен по всым частянь свтта и сшитаетя од-

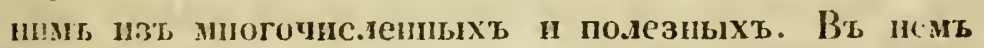

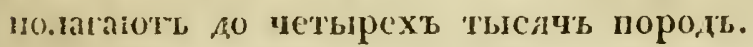




\section{PA3HORHAHOCTI.}

A cacia stricta. longifolia, trinervica, semperflorens, liuiPolia, vevticillata. juniperina, obliqua, suaveolens, heterophylla, lloribunda, myrtifolia, latifolia, paradoxa, mueronulata , glancescens, decipiens, longissima, mœsta celastrifotia, macradenia, leptoneura, oncinophylla, squamata, argyrophylla cylanophylla, diffusa grandis, oxycadras, petiolaris, riccana, urophylla, viscidula, julibrizin, farnesiana, leucocephala, pudica, botrycephala lophanta, lebbek, pudesceus cornigena quadrangularis, aculeaticarpa, eburnea, dealbata, cultiformis, rotundifolia, grandiflora etc.

ACACAA foliis triangularibus vel deltoïdeis, augulo exteriore spinulosis; stipulis setaceis, caducis; ramulis glabris; capitulis globnsis, axillaricus, pedunculatis, $7-10$-floris.

ACACEA decipiens. Hort. Kew. ed. 2. vol. 5. p. 463.Bot. Mag. n. et. t. 1745.

По Французски Acacie trompeuse.

Отечество Повая Голдандія.

Acacia decipiens сажагть въ горшокт вт верескив!ю зем.лю, льтомь выставляють на воздухъ, зимой содержать въ оранжереь. Размножается отводками и сынянам. Цв'ьтеть въ апрыль и мат.

Въ вышину это деревцо доходить до 4 Футовъ.

С́ебель состонть изъ многихъ тонкихъ в'ьтвсї, составлищцх густой кустъ.

Листьл треугольные, безь хвостиковъ, темнозелеиые, гладкіе какь и остальная часть растенія, имьгть одну жилку, ноторая находится у наружнаго лрая и выходить остріемь изь угла.

Цвыты ичеиь маленысе, блtдно-желтые, шаровидные, соединены вмысты оть 7 до 10, сиднть на ножит д.лиnнте листиа. 
Ннжняя часть цвьтка однолиственна, бльдновата.

Выншикъ состопть из' шести овалыныхь раздылеnій, одниаковыхъ и отірытыхь. Тычниокъ около ста, пмьоть мочкп иитеобразиыс, вт по.іовниу меи'ье в'ыпчик, окапчиваютея округлепными головками плодотворной тычник. Зародышт пунистыи, сверху котораго иаходптся продолговатый столо́нкь, д.пинце тычпнокъ, оканпвающійся обынновенымь устьемь.

Акацій болье всего въ Анерикь; описывасмый же видь быль прнвезень въ Аитлію вт 1805 году.

Пз'ь Акацій, травяпистыхь пьть, всы опь образуютъ: деревья, деревцы нли ғустарнини, замьчательны своею разнообразной тормої.

Разнцц, существующая в'ь образованіп в'ьнчна

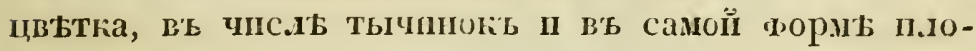
да и зерепь растенія, которое Лнней соеднииьь въ своемь родь Мимозь Mimosa, дали поводт Вильденову (Willdenow) раздьлить этоть родъ, сдъ.хашшійся очень многочисленнымь; таћь что Линей ститаль ихь пятдесять, а теперь до двухт сотъ. Нзъ числа Мимозъ новый родъ, получишій названіс Акаціи, самый мпогочисленный; въ пемъ бо.ґе ста разновпдпостей; почти вс' он прниад.ежать жаркимь странамь свЂта.

(cm. Her. Gen. 1 66.)

I. I. 


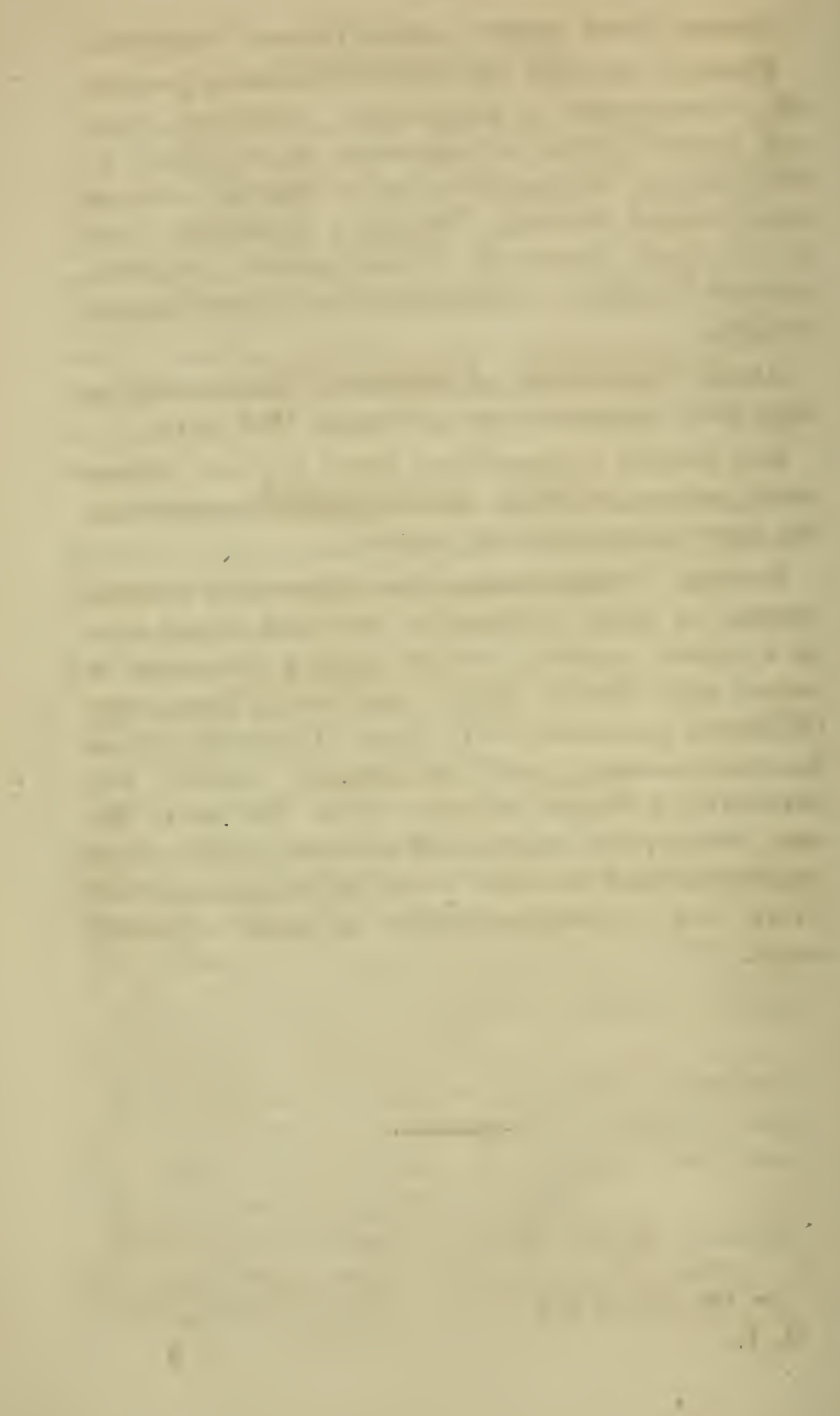




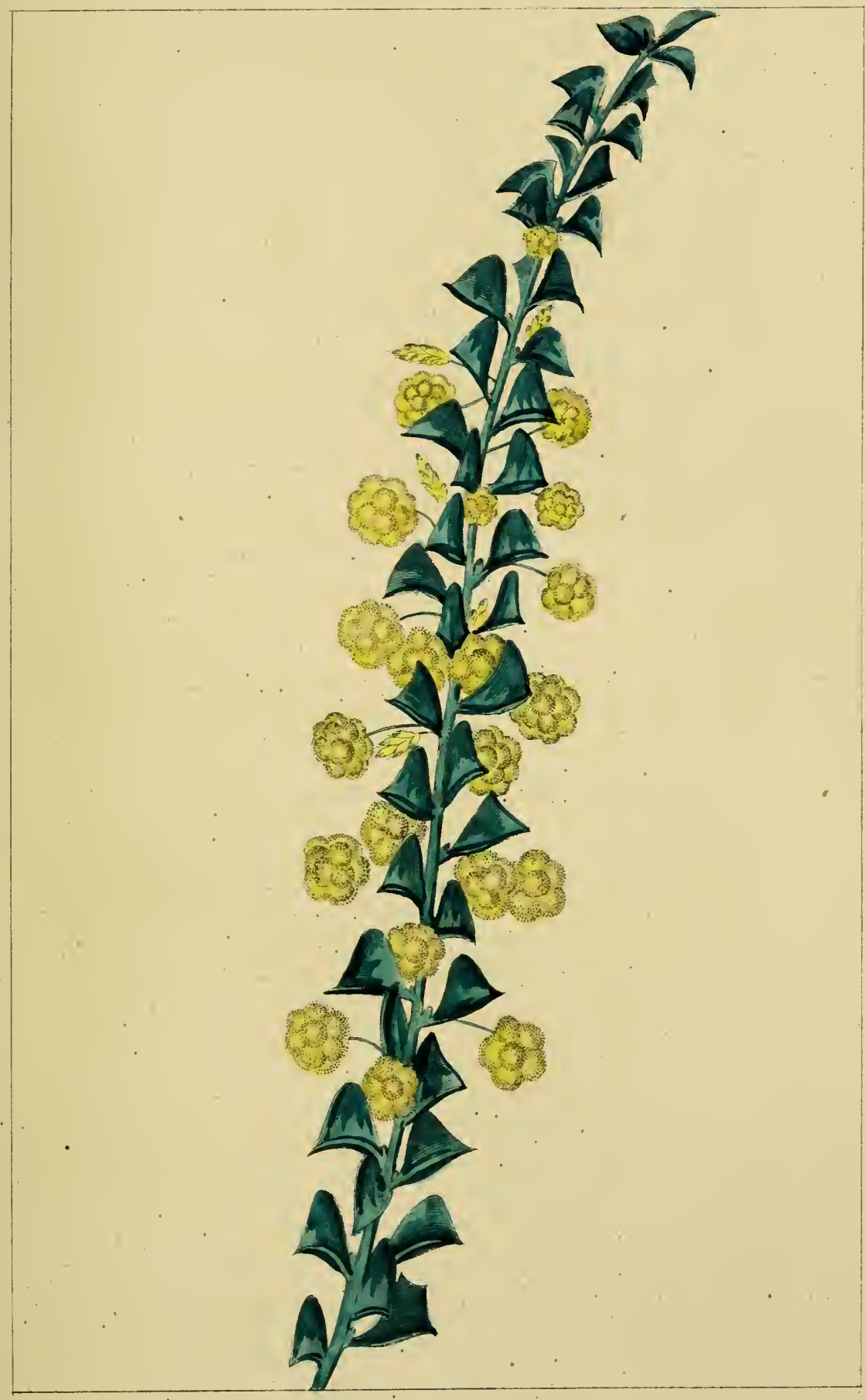

- terisire iecifuens.

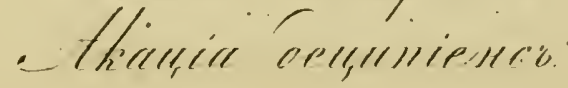





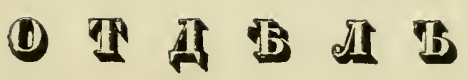
T P Е T I Й. 



\title{
COPГO GАXAPHOE.
}

\section{SORGIUUI SAGCHARUV.}

\author{
HOLCUS SACCHARATUS.
}

Селейстоо Злаковьхх. Gramineac.

\section{OSEIIII XAPAHETEPT。}

Ростенія, прннадлежація къ этому семейству, ростуть во всыхт частяхт св'та. Собственио вт садоводств' ихъ очень ма.ло. Почти всь прннадлежать се.льскому хозяїству : зерна доставляють х.льбы ; .истья служать д.я кориа скота; стебель нькоторыхт пзт пихт содержить сахаръ; иорп другихт употребляются вт Медиџниь. Разиножается съиянами, раздыленісмь корней, отводками и черенкамп.

По Француски Sorgho à sucre.

Отечество-Восточная Индія.

Довольно обынновено въ Сенегамбін, гды его называють Кафе, и въ Нигриці-Макари.

Сорго растеніе однольтиее. Корень мочковатый объемлющій; оть пего чдеть оть трехъ до шести стеблей, 'гравянистыхт, узловатыхъ, шилиндрическихъ, напо.пениыхъ макотью, вт вышину отъ 7 до 10 Футовъ, 
образуя кустъ. Листья узкіе, основаніемъ объемльощіе стебель, поперемьнно спдящіе, увядающіе. Щвъты расположены въ видЕ метелки прямой и довольно сжатой. Сымана кругообразныя, блестящаго чернаго цвъта.

Размножается съмянани, раздыленіемь густов'ь и черенкамп. Почва чериоземь, ростсть хорошо іл на глинсто-черноземной. Сьютъ вт парникъ и.лі въ паровые гряды, въ апрьль; въ половигь мая, когда можно не бояться морозовъ, высаживають на мьсто, такъ чгобы растеніе сидь.ло одииъ оть другаго оть $1 / 2$ до $\frac{3}{4}$ арш. не болье. На десятннь можеть рості оть 33 до 34 тысячт кустовъ.

Сьиянь па десятниу полагають оть 4 до 5 фунтовъ. Первыя сымяна сахарнаго Сорго были вывезены вт Парпжское Геогратпческое обцестьо въ 1850 году, н надъ ними дњлали опыты извьстные садоводы; изъ иихь Франсъ (dе France) по әтому поводу писаль къ Ванъ-Гуту (Van Houtte): “Трп года тому, какъ я получнль сьмяна этого растенія виьст'ь съ другими, вывезениыми изъ с'ьвернаго Китая, подъ названіемь сахариаго тростина. $\boldsymbol{Я ~ з а с ь я л ь ~}$

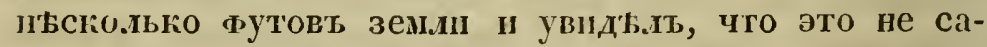
харпый тростниг, а Сорго, отлпчаюееся отт обыниовениаго сладинт согомъ и черпымъ цвьтомь

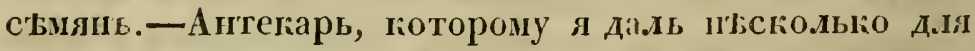
опыта, сказаль, что изъ сока образустся сыропт, подобный получаемому пзь 12 частеї сахара съ 100 частями воды.

Сборъ стмянь былт равенъ посьву; выжатый сокъ не доволғно сладокт и травлишстаго вкуса.

Не смотря па әту неудачу и прншмая во впммапіе пеобыкпвенню погоду прошлаго льта, я рқшился посьять вновь ІІ въ этомь Году, ПодучНлт, реаультать довольно удовлетворителыный, пенио: 
иа двадцати пвадратиыхь метрахь, „і соб́ра.1ь 40 килограновт стеблей, па почвы r.инистий, дово.ино жесткой и трі года пеудобрасмой; шзь чего я зак.лтиль, что разведеніс этого ростенія тант не .егцо, какт и обынновениаго Сорго.»

Опыты Вильморепа (Louis Vilmorin) были гораздо удатије. Вотт что огт пишете о сахарномт Сорго (Moniteur Universel, le 18 Novembie 18\%3).

"Стсб.п Сорго, отищениье оть пистьевт и изрызаниые па кусли, могуть быть раздавлены въ обык-

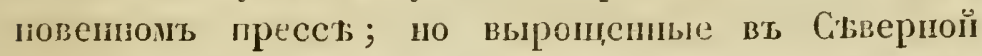
(D)анціп дають сокъ, зак.иочающій вт себ̈в ма.ло

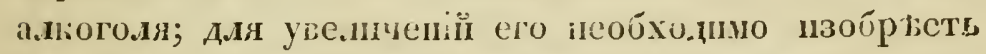
ередства: 1 выстав.ияя стеб.ли въ продолженіи пь-

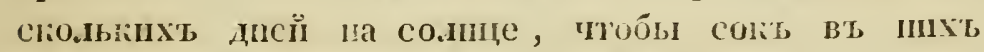
зак.ючающійся сгустияся; 2 н.и достигая әтого пскусственимь о разомь, клада стеб́.и в’ печь, въ волыы духъ и 5 сгущая сокь чрезь пепарепіс жидкости, выдавленной прессомь.»

Потомь сльдуеть описаніс добиванія изь сока водІї.

Аалье Вильоренъ пинсть: аСахариое Сopro стоть рядами, чтобы можно было, пока ромтеніс молодо, подонать его и овучияать. Развсденіе тереніами неудобопсполимо, потону что трости то.іько вт сентабрь становятся тверды, ІІ по прлтяости ості-

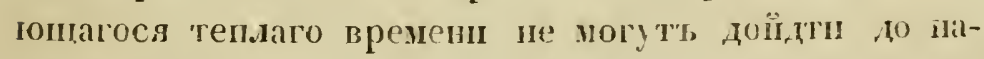
д.лежацей величпы. Оть раздьленіл тоже ма.10 будеть пользы; растепіе не будеть пуститься, по этому иадо будеть сажать чаше, тто выйдеть одио и то:ке; то.лько трудт пропадеть дароне.

Танъ какъ трости трудио сохранлть долгое время, то нхъ можио бы сушить на со.иц'Б; оть әтого работы при добывашіи сахара не остапв.лиа.ись.» 
У насъ на юог дылали много опытовъ и результать быль очень удовлетворнтелент, какь видно пзт статып Ииспегтора Сел. Хоз. гожиыхъ губ́срній А. Н. Стругова, помыщенной въ ЖКур. Мин. Гос. Имущ. 숭 1, за 1856 годъ, гдь очень подробно описаны, кағъ зेаграпшпые, тағъ и наши опыты, надъ Сорго.

OБGЯCHEHIE PICYHICA 3.

1. Толщина трости въ настоящуго ве.ичину.

2. Форма нолоса съ сымянамп. 


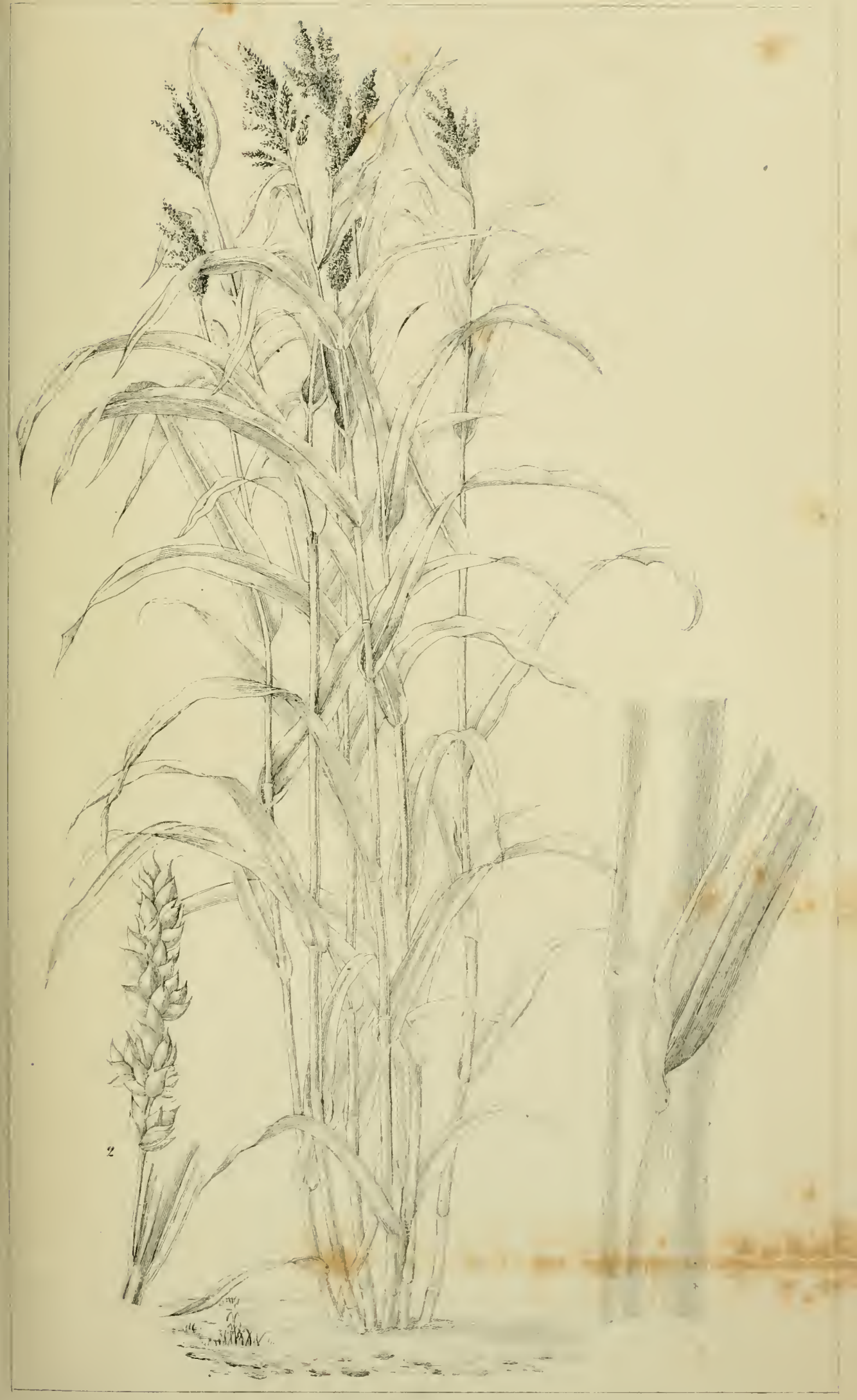

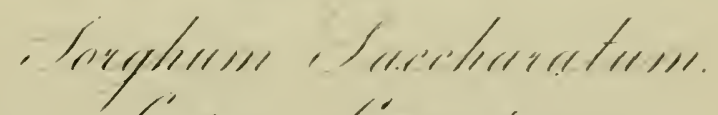
lépere lerenerfererese 



\section{HIOCROPEA БАTATA. DIOSCOREA BATATAS.}

PHANEROGAMAE-MONOCOTYLEDONES.

Cелейстоо діоскорейньхъ. Dioscoreae.

\section{OBGHELIII XAPAKTEPT.}

Одио пзт пемногочисленихт семейсть'; растенія, припдлежащія кь нему, вьющіеся п џьиіе кустар. нию; листья ст сттчатыни жнлками, сердцеобразиые или угловатые; цвтты маленысіе пе очепь ираспвые; горни очень толстые, масистые. Размиожаются раздылсніеиъ корней и съмянами; ростеть въ тучной почвь. Отечество-жкаркія страшы.

По Французски L'Jgname Battate.

отечество Kuтай.

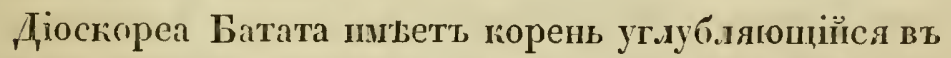
землю перпендикулрно, величина его зависитт оть болье пли менье глубокаго разрых.ленія погвы ІІ прсницателыости ея. Видемъ оиь похожь иа булаву; толщи вь самомь большемь обьем' съ пулакъ, кь верху печувствителюно съуживается, такт что доходить до толцииы пальца. Спаружи горень покрытъ темнокраспой пожицей пли цвьта молока ст гофе; 


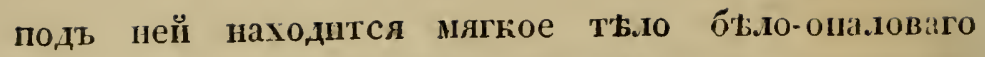
цвьта, доволыо рыхлое, крахмаллитое с'є соколь

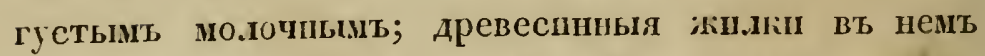
едва зальтны. Посль варки кожица дылается- нықною и вІуељ пория трудно от.ичнть оть Іартофс.А. Одпо растеніс можеть дать ићсколько лорнеї, но бо.ишего частью ихь бываеть три илди два. Корень

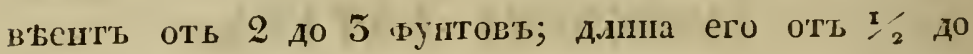
1 аршина и болье.

Стеб.лI доходять оть 2 до шину цилиндрпчесліс, въ толцину $1 / 4$ вершй, выощіеся сь права вь льво, темнозеленые ст лиловымь оттынконт; оставлениые на собственный пронзволт, они разсти.гатся по зем.и', быстро унорепяльь. Iистья противуполоние, что весьна замьиате.юно въ растеліп однопо.овнчатомь; треугольно-сердцеобразиые, в'ь верху зыосгрешы, а в'ь раздвоени у стеблд олруглешы; глдиіе, блестяшіе, темпоеленые, спдяціе па чсрепнахт вт по.овпну мепье листьевъ; пересьчены ссмыо или девятыо г.ивпим жшлкан, сходящимея въ верху, между пим рнсуется еьть второстепенных жилокт, пересьиащихея между соболо. Џвыты маленьіе, б.вдносиніе,

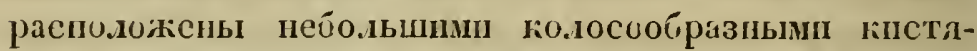

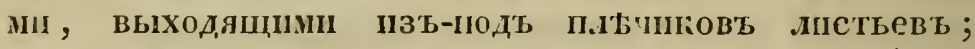
юаждый пзт нихт состопты изь шеси депестковъ; три паружиые округлепы, трп виутрепне меные

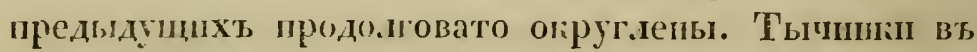

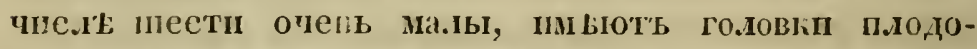

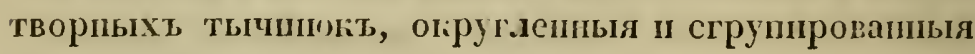
въ средин' цвьтка.

Описываемое растеніе было прпс.лано, шееть льты тому назадь, въ Парижт, транцзспим консулонъ въ Щань-Гап $\Gamma$. де Monтmй (De Montigny).

Bot女 tто оI'L o nеMt пHшеть: 


$$
\frac{k 1}{6 t}
$$



«Сенъ-Пиъ (Sain-In) въ большемъ употреб́леніп въ Китағ; родится въ большомъ количествт, и дсревенскіе жите.ли употребляють его въ пищу, какъ на Стверь Европы картотель.

На съмяна отбираготь самые маленькіе коренья; па зпму ссыпають въ ямы, хорошо перекладывая со.омой и засыпаютъ зсм.лею. Весної вынпмаютъ изъ я.м ІІ к.ладуть вт пебольшомъ одинъ оть другаго разстояніп въ борозды, прнготовлениыя на земль достаточио вскопанной.

Въ очень короткое же вречя они всходять, п когда п.лети достигнуть одиого или двухъ метров'ь, ч'о бываетъ ойыниовенио чрезъ мьсяцъ пос.ль посадни, то ихт выниають, ттобы разводіть терсикамн; это дь.лерся сльдующимь образомь: Вепахавт зем.но, ды.лають заступомт борозды, по.ложивт вьтвI, ихъ слегка погрываюте зсмисе, такт, чтобы листьл были наружу. Если въ тотъ же день пойдетъ дождь, то оип пемедлепно прпшшаются; въ противномь случа' ну;но поливать, пока растеніе не тропется въ рость.

Урезъ 15 и.ли 20 діей ойразугтся въ зсм.ь пиш-

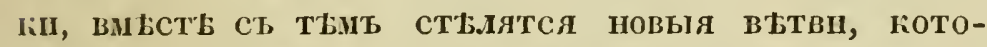
рыя падо времл оть времепи приодымать; пиаче огь укореняются, что вредить росту корсньевъ».

В'ь гишгь, подь заглавіемь 'Ти-ли-Кинг, т. е. пина пронзедспій зем.ли, с.льдующес мъсто также отиосигея пь иькоторымь породамь Діоскорсйпыхт, и пзь иихь болье всего кь дорскореа Батата

“iогда корень очешь д.шиень, его разризывають на пускі и сажають. Въ тоть же Гидт сь пего можпо собрать коренья, которые зарыьають вт зем.ио д.я храпсиья. Веспой вырываготь ихт изъ зем.ии й сажагть. Надо остерегаться удобренья че.овьческаго, а унотреб.лять толы: павэз коровій, пере-

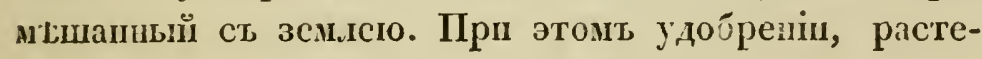


nіе быстро пойдетъ въ ростъ и вскор' дастъ плодъп. Накопецъ въ Ву-Пен-Си-Шу пишуть относптельно обработкп ІІан-Іо: “Немного ранъе пли позднъе времени называемаго Ган-ШІп (4 апрь.я) выбирають песчаную мьстность, которую прорызывають рвами д.пиюю около тридцати аршии и глубннй около аршип; потомь иаполняють ихъ сиъсьо изъ равныхъ частей земли и коровьяго навоза, хорошо перегпишаго. Наконець разрқзав'ь коренья па куски, и.ладуть по рву, какь кирпич и.лп терепицы крышъ и засыпають пебольшим слоемъ той же смьси. Если времт сухо, поливають умьренно. Особенио надобно пзӧьгать удобренія человьческаго.

Когда п.лети разростутся, ихъ поддерживаготь тычинамп. По прошествіп Шоанъ-Кннга (20 огтябрл) и прежде промерзанія земли, вырываютъ коренья и сохраняють в'ь погребахь; сберегая какт. можно болће оть морозов L. .

ОВЂЯСТЕHIE PICJIKA.

9.

Корень разръзанныі на двое, въ настоящую ве.ичину п стеóe.ль.

10.

1. Стеи́е.ль, листья и цвиты.

2. Кории въ уменьшениомъ видь. 



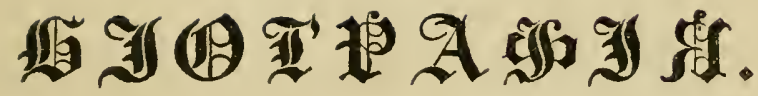





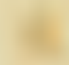




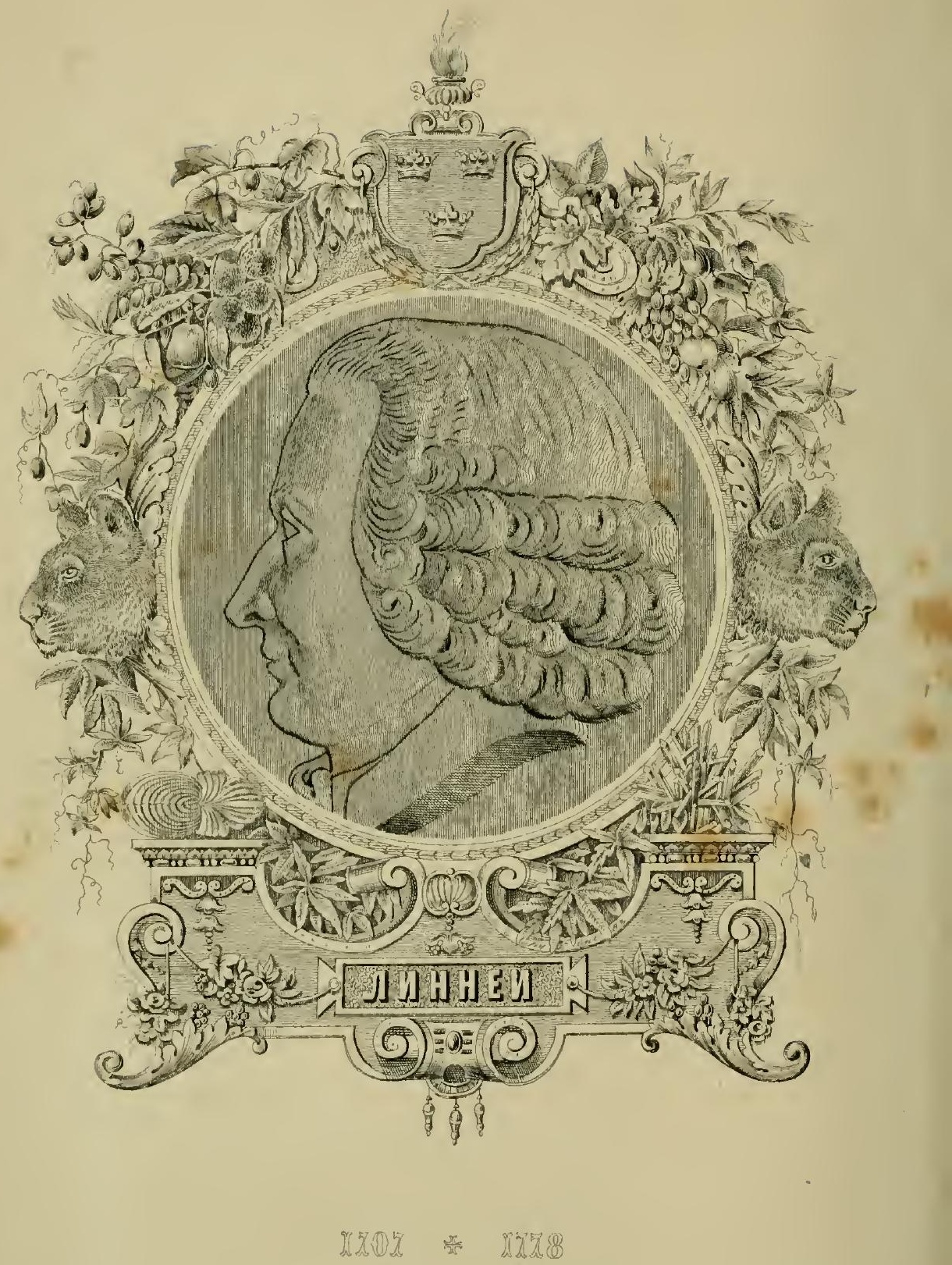




\section{КАР Я Ъ АИННЕЙ.}

Въ 1707 году вт, одиой изъ бъдныхъ деревушект Швецін, Россгульть (Roeschult), у пастора родплся сынъ. Отець, видя свое б'љдное состояніе, отдаль его учиться въ Вексіое (Vexsiœ), но замьтивъ, чго онъ оставляетъ клдссъ, чтобы идти вт поле собирать цвњты, отдаль въ ученіе къ башмачнику; но не такт думаль докторъ Ротманъ (Rothman), бывшій другомъ дома, и упросп.љ пастора перемьнить әто рьшеніе II вмысто башмачншка сдылать изъ пего доктора; отецт согласнлся. Ротмант вшдыль большія способности въ ребенк'́ и, давъ ему әкземплярь Турпефора, помьстиль его къ профессору натуралынй псторіп Kпліане Стобаеуст (Kiliane Stobaeus).

Башмачищкъ, докторъ и потомъ великій блтаникъ! но подобныя странпости почти всегда случались съ людьми геніальнымш.

;iera пастора страсно любила цв'ты и во время беремениости Карломь, съ любовью сльдила за мужемъ, обработывающимъ свой скромный садикъ. 
Въ пос.льдствіп ни тьмь не могла она тапь скоро успокоить ребенка, какъ давъ ему цв'ьтокъ; если онъ плакаль, то видъ пвьтка застав.яя.и пзчезать слезы, и оиъ становился весе.п. Сь льтами страсть эта уси.ли.гась. Оть профессора Стобаеуса, Аиней поқхаль учится въ Упсаль, гды долго жиль в'ь большой крайності п чтобы добыть себь хоть сколько шибудь денегъ, прпнялся за переписку бумагт, а потомь сталь давать уроки латинскаго языка друтимь ученпкамь, и прп слугь, вспомив'ь прежнее свое предиазиаченіс, чпния ихъ башмакII.

Профессорь ботаники Олаусъ Рудјекь (Olaus Rudbeck) поручпль ему управленіе ботаншчесішмь садомь въ Упсаль; прпвода все въ порядокъ, онъ увпдыль ошпо̋ки старой методы, п это подало ему мысль о реформь. Спустя ньсколько льть, повая свьтлая мысль сдьдалась для него какт бы вторымь открытіемъ; ему хотьлось пазывать растенія двумя словами, вмьсто хотя харагтеристическихь, но очень длинных тразъ Богена (Bauhen) нли Турнефора (Tournefort).

Въ 1732 году, по порученію Упсальскаго Ученаго Королевскаго Общества, опь сдьлаль путешествіе в'ь Лаплапдію для собирапія п описанія растеній. По

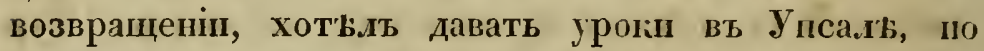
интригі профессора Розеша (Rozen), боявшагося его превосходства, принудили его удалиться въ Фа.иугь (Fahlun). Отскода онъ потхаль вь Гамб́ургт, а потомь въ Голдандіо, чтобы учиться у знамешитаго Биергава (Boёrhaave), который съ нимь подружнлся и позакомиль его ст богатымъ дюбителемь Георгіемь Клифортомь (George Cliffort), у котораго Анией прожиль три года, и въ честь котораго наппса.хь: Hortus Cliffortianus. 
Оставляя Аейденскій университетц, оп пошель проститься съ другомь и учителемь Боергавомь, которыї въ әто время быль старъ и почти умирающій. Обиявъ его, Боергжвъ сказалъ эти трогательныя слова: “Я когчиль мого карьеру; да сохранитъ тебя Господь иа пачинаемомъ тобою поприщь! Ученый св'Бгъ получиль оть меня то, чего ожидалъ; но оть тебя онь ожидаеть бо.ье. Прощай, мой Аинней! Прощай, сышъ мой!’

ІІріемт, сдбланный Линею въ Англіи знаменттьйшимш нат: ралистами того времени Слоаномь (Sloane) и Днлленіусомт (Dillenius), быль такъ холоденъ, что онь не долго тамь пробыль.

Линей посьтиль Іарнжт вт 1738 году, пмья реғомендательное письмо кьь Берпару Жіюсье (Bernard de Jussieu), отх Baиъ Poena (Van Royen), заступившаго мьсто Боергава. По прівздт, он'ь прямо пошелъ въ королевскій садъ, гдь засталь Жюсъе, пз'ьясняющаго уроки ботаникн - онъ показываль ученикамъ новое ростеніе, и спрашиваль, можеть ли кто-нибудь узнать по наружиымъ признакамъ его отечество? Всь молчалі, вдругъ голосъ изъ толпы сказаль "Facies Americana" физіономія Амерпканская. Жюсье съ жнвостью обернулся и тотчасъ отв'bчалъ: «Тu es Linneus?» Вы Линееи?

“Да” отв'ьчаль Аинней и подаль рекомендательное письмо, въ которомъ Ванъ Рогнъ называль его князсмь ботаники.

По возвращеніи въ ІІвецію, Лнней вскорь, покровительствуемый графомь Тессинт (comte de Tessin), назначенъ былт первымь догторомъ короля и презшдентомъ Академіи наукъ и наконецт вт 1741 году профессоромь ботаники въ Упсаль. Ему пришлось занимать ә'гу каөедру въ продолжеиіи трпдџати се-

I. I. 
ми льть съ блестящимь успьхомъ. Вь әтотъ длиниый періодъ опь воспо.ьзовияся, такт же кагт Бюфонъ, свопмъ вліяніеиъ и всьми завпсьвшими отъ него средствами старался распространить п усовсршенствовать иаугу; собрать начала свопхъ трудовт II чздать Пхь.

Онь заставиль дать порученія учениамь, которые въ посльдствін со всьхт точегъ земнаго шара ириносн.и ему обшириые матеріалы.

Натураллсты всего міра спьшили представить ему все, что погитали достойным' его.

Сu всыхь сторонь, по прнмьру Швеціи равно какт и Фрапцін, другія націн старались спосиљшествовать этому чудиому полету науни ещс повой.

Аннней получаль отъ всыхт Ученыхт Обществъ, отт всьхъ монарховъ самыс блистатель!ые знаки уваженія; но эти почссти не изиьшли нимало его простоты, віусов'ь и прнвычекъ.

Критки иа разиые топы тоже зажузжали против' иего, по онт пе удостоп.т ихъ даже отвттомь.

Знаменттйшее изъ сочиней его: Ботаншческая Фплоспжія, пзданна въ $175 \mathrm{1}$ году, въ которую вошли мюгія пебольшія сочшненія, иаппсанныя имь иодь разиын заг,лавіями, и которыя служнли какь бы прнгтовленіемъ пъ пей. Это-трудъ, псполненный учсиости и новыхт возарыній, прсдставлен слогомь самостолтельнымъ, возьышеннымь и часто поэтическимт.

Оит сдБлался осиовпьмь закономь ботаниковь, иравп.а его были прнмыены къ другимь отраслямь натура.циой исторін.

Изт вс'ххт сочиненій Аиниея самыя замьчательшыя сльдующія: Systema naturae, въ пачаль состояцая изт трехт только листовъ; была иерепечатываема миого разъ и дополионялась всьуи нов'ьйшич откры- 
тіями, она прнияла чрсзвьчайыье размьры до того, что четырнадцатое изданіе заклочало уже десять томовъ. Первые три листка былп напетаташы вт 1735 году вт Лейдеиь; второе пзданіе вт, 1740 году заклочало уже 80 страниц; шестое 1748 году в' 232 стр.; десятое въ 1757 году въ трехъ томахъ; двьнадцатое вт, 1766 году въ 4 томахъ и наконецъ четырпадцатое въ 10 томахъ, пзданыхъ Гмелином (Gmelin). Fundamenta botanica, папечатано въ Амстердам'ь въ 1736 году; Biblioteka botanica тоже вт 1736 году; Classes, plantarum вт ЛЕйденғ въ 1738: Critica botanica вт Штокгольмы вт, 1751 году; Genera plantarum в'ь Лейдеи'ъ въ 1737 году; Flora Laponica в’b Аистердамы в'b 1737 году; Fauna Succica в’ь 1746 году.

Если испусственная система Линея и должна была уступить простой натуральной методь Жюсье; то это ие могло быть съ его номенклатурой , которая осталась въ наук' и кией вс'ь ботаники вообще сльдують. Тоже можно сказать и о Ботанической Фплософіп, сохранившей до иашихъ дней сное высокое достопнство.

Линей соединяль вс' пеобходимы качества для успьха велиюих вшдовъ; онь подвель вс'ь пропзведенія природы подъ иовый законъ; создаль для наукп особый языгт; его ученіе распространилось и преобладало во встхъ школахъ болье поль'ка.

Его бесьда была тиха, тьерда, псполиеша прелест!; его благосклониость II набожность нскренны; ревность ІІ д'влтельность неутомимы.

Главпе ето пазпаченіс-быть велипит профессоромъ, капт Бтофона велинит философомъ. Къ иеснастіо, различіе мивиій всегда разд'ьлло этихъ двухт геніалыны людей, которые еце бы усплили ходт науки, сслио̆т согласи.ись и соедпнились д.я с.луженія ей. 
Линней умеръ 10 января 1778 года апоплексическимъ ударомъ 71 года. Онъ отказывалея постоянно отъ предложенія многихъ монарховъ, желавшихь привлечь его. Отвытъ всегда былъ одинаковъ: “Талантъ, данный мнь Богомъ, я обязанъ посвятить моему отечеству." Потому-то Густавъ III достойно почтиль его, написавъ надгробное слово великому ботанику, пролившему на Швецію славу не менње блестящую и конечно болье прочную славы его несчастнаго короля. 



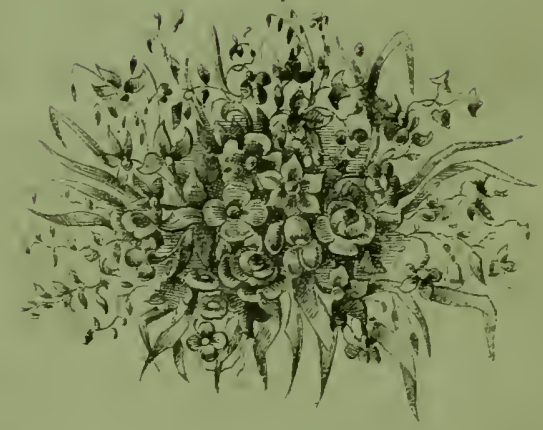

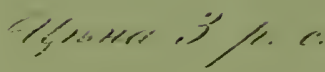




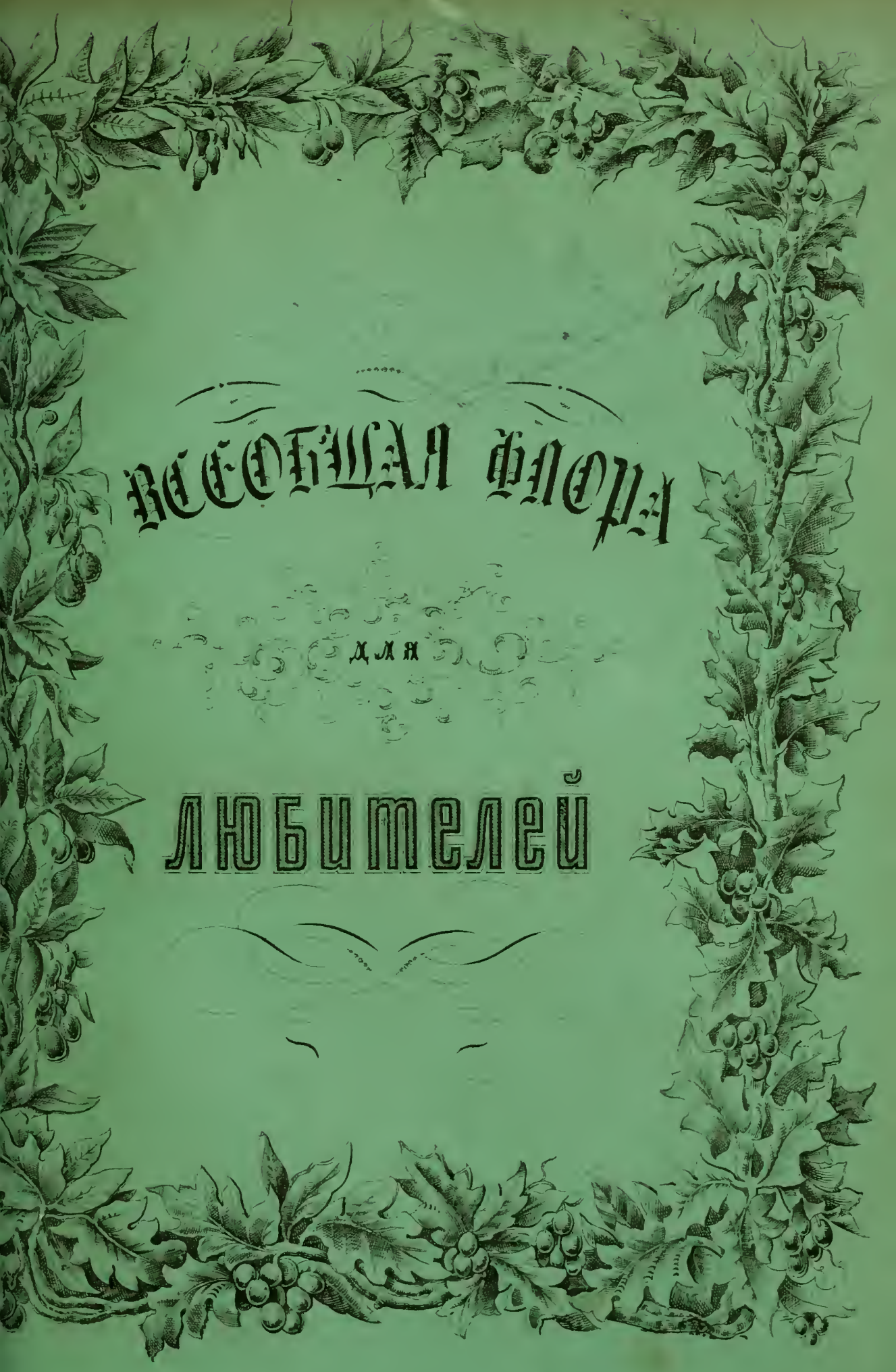





\section{ВСЕОБЩАЯ Ф.IOPA.}

$$
\text { A } 1 \text { Я }
$$

I HO $\mathrm{B}$ И T $\mathrm{T}$.I E 


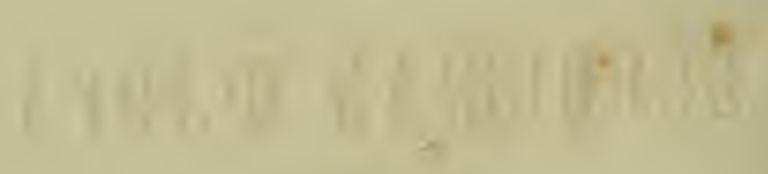

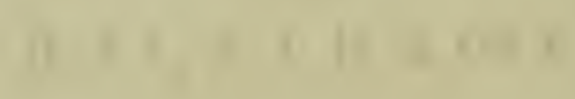

$+$

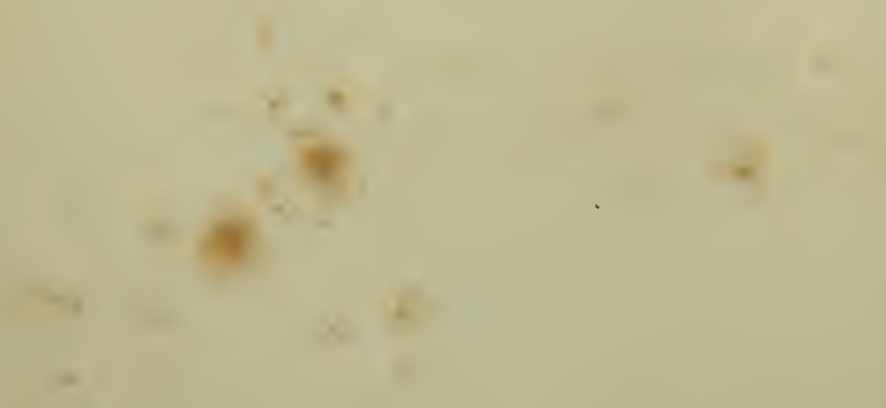




\title{
ВСНОВШАЯ ФJОРА
}

\author{
A I I

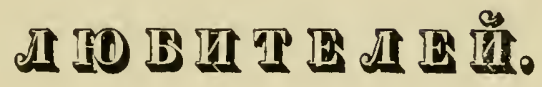

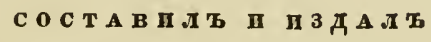

А. Ч. Россійскаго Оӧщества Любителей Садоводства и Комитета Акклпматизаціи растеній.

II. В. Романовъ.

ЧАСТЬ ВТОРАЯ.

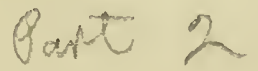

M O C F B A.

ВЪ ТИПОГРАФІИ Т. ВОЛКОВА И КОМП.

1858. 
ПЕЧАТАТЬ ПОЗВОЛЯЕТСЯ

съ тьмъ, чтобы по отцедатаніп предстанлено было въ Ценсурный кіоптетъ узаконенное ппсло экземпляровъ. Москва, Јюля 21 дня, 1858 года.

Ценсорз Н. Безсо.иыкинг. 
(1) TA A D

I Е Р В ЫЙ. 



\title{
AMAPII.LIUG' УILL.IATA.
}

\section{AILAYLLIS UNDULATA.}

\author{
HEXANDRIE-MONOGYNIE.
}

Селейстоо Алариллисовьхь. Amaryllideae.

IIo Французскі, Amaryllis ondulée.

По Ньиецки, Wellenformige Amaryllis,

По Англinicki, Wave-flowered Amaryllis.

Отечество нысъ Д. Надъжды.

Названіе Амарнллиса можетъ относитса къ поэтпческому и пастушескому, потопу что самые зналенитые поэты пастушескихъ стихотворепій: Теократъ (Théocrate) и Виргилій (Virgile) давали его свопиъ пастушкамъ, украшая ихъ всыми возможными прелестяп, какіе то.ько вымысель поэта могъ представить. Сравненіе это очень пдетъ къ растенію ищьющему пного разиовидиостей нзъ которыхъ болыная часть заслужнваетъ внимапіе любнтелей: қрасотою, блескомъ, величиной пли запахомь цвьтовъ.

Названіе Амарилигса происходитъ отъ греческихъ

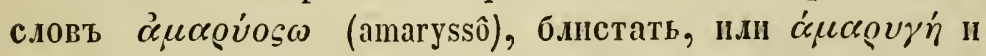

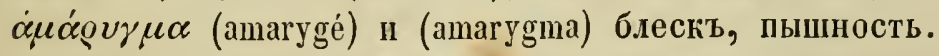

Полагаютъ, что Анарилисы сдђлались извђстны въ Европь съ 1777 года. 
Ухсдъ за Амарплисъ ундулата, очень легокъ, и если дуковица довольно сильна, то она всегда зацвьтаетъ въ сентябрь или октябрь. Сажаютъ ее въ горшокъ въ вересковую землю; поливаютъ умьренно; льтомъ выстав.яютъ на воздухъ, зимой содержатъ въ оранжереъ. Когда листья засохнутъ, отдъ.яютъ молодые луковки, а старой даютъ новую землю. Сьмена Анарнлисъ ундулата иногда вызрьваютъ; можетъ быть они созрьвали бы вырнье, если бы луковицу содержать сухо, сколько будетъ возможно безъ вреда для нее; въ ноябрь посадить въ горшокъ, тогда цвьты показались бы весной, и сымяна въ продолженіи льта достигали бы по.ной зрь.лости. Они да.ли бы, какую нибудь интересную разность; собственно же дяя размноженія луковицъ не стоптъ труда собирать сьмянъ, потону что посль посьва они зацвьтаютъ на пятомъ или шестонъ году.

Луковица овальная красная, она до.жна быть ве.ичиною почти съ грецкій орбхъ, чтобы мог.иа цвђсти, корни тонкіе, мяспстые, бъ.ые. Ежегодно они даютъ отпрыски пзъ четырехъ или пяти листьевъ узкихъ, же.лобковатыхъ, тупыхъ, не ровныхъ въ длинну; изъ нихъ длинные загнуты, а короткіе прямые. Съ б.оку листьевъ выходитъ зеленый, гладкій, цилиндрическій стебель, д.линье лпстьевъ, оканчивающійся зонтикомъ изъ двђнадцати или пятнадцати б.ьдно-фіолето-розовыхъ маленькихъ цвьтковъ.

(en. Her. Gen. A 5. .) 


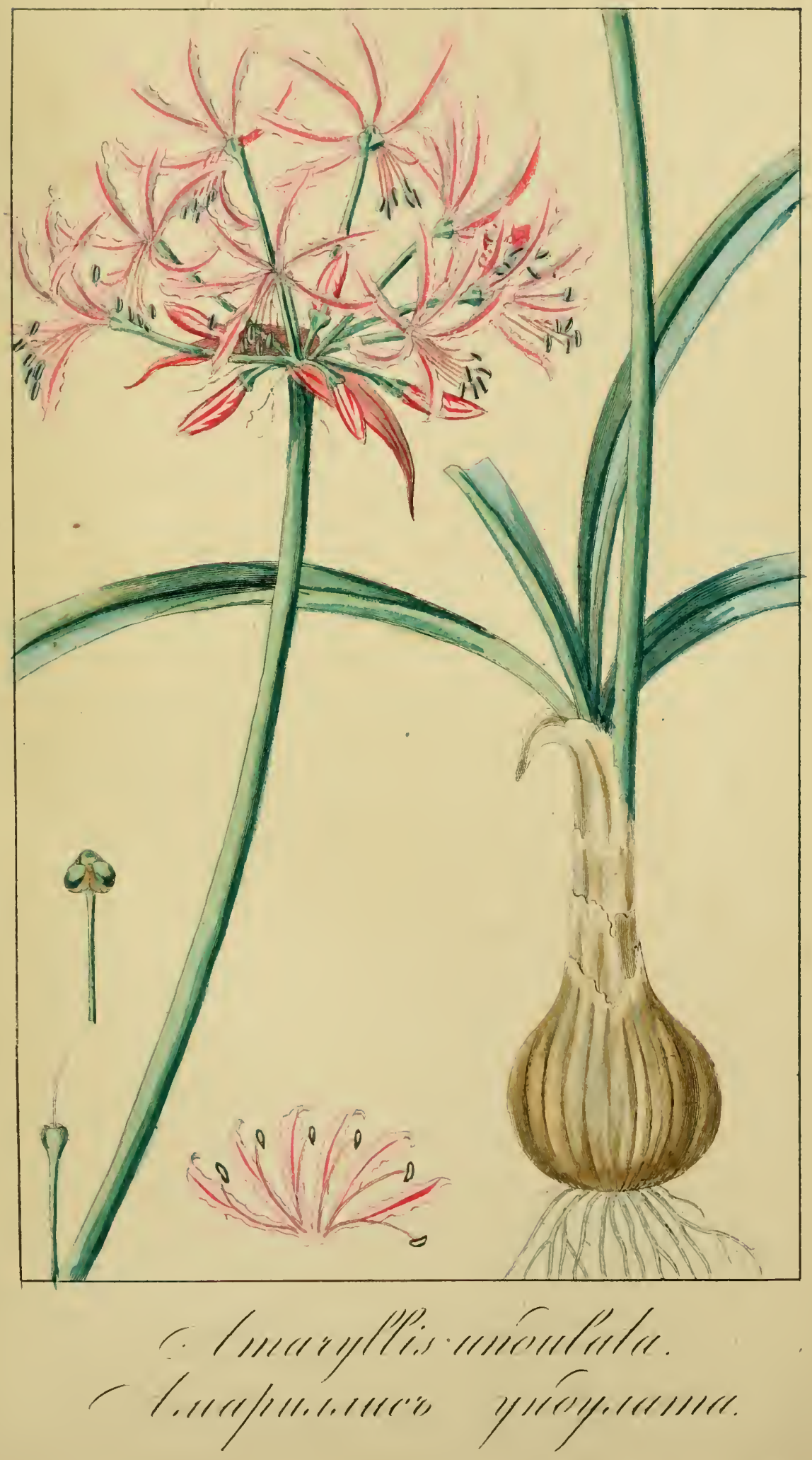





\section{AHARA.LIUCT MOHEd.IИ.}

\section{ANAGALLS HONELL.}

PENTANDRIE-MONOGYNIE.

Сеиейство Перооцотьтовыхъ. Primulaceae (Ventenat).

\section{OEULUII XAPATETET.}

Растенія, принадлежащія къ этому семейству, травянистыя, съ листьями противуположными. Чашечки и вънчики правильные, имьющіе отъ четырехъ до пяти лопостей; тычинокъ обыкновенно столько сколько и лопостей; столбикъ одинъ и съ однимъ рыльцемъ; плодъ состоитъ изъ одногнъздной коробочки. Семейство это находится во всьхъ странахъ свъта, прениущественно же въ сbверныхъ и на самыхъ высокихъ горахъ.

Ilo Французскі, Mouron a feuilles étroites.

По Ньмеци, Aufrechtes Gauchheil.

Ilo Aнгxiйckи, Italian Pimpernell.

Отечество Испанія.

Не думаю, чтобы можно бы.о видъть, что нибудь пріятне Анагалиса, покрытаго льтомъ голубыми цвытами съ кармннныз пятнышкомъ посрединъ; маленькми әто правда, но чрезвычайно красивыми.

Монели (Monelli) первый нашелъ это растеніе въ Италіи и послалъ къ Клузіусу (Clusius), въ 1562 году, 
которып̆ пІ далъ ему пмя друга, приславшаго его; это има сохранилось до спхъ поръ. Съ этого временг оно сдылалось пзвъстнымъ ботаннкамъ, и его стали воспाтывать въ колекціяхъ. Потомъ въ продолженіе нткотораго времени Анагалпсъ какъ бы пропалъ совершенно, но благодаря Стейну (Stein) продавцу цвытовъ; снова явплся въ 1802 году.

Содержаніе п уходъ за этимъ миленькит цв'ткомъ очень легокъ; онъ часто выростаетъ отъ сынянъ, пиъ самимъ разбрасываемыхъ. Сынна сыются тотчасъ по созрьніп въ питательую зел.ю; по всходы разсаживаются въ трехъ вершковые горшкі. Когда начнетъ выростать, надо поддерживать травянистые, тонкіе и способные стлаться по земль его стебли, колышкам.

Стеблі эти четырехугольные струічатые, также какъ и промежуточныя вытви, иногда поперемьно спдящіи и даже, какъ бы прнкрвп.енные отъ трехъ до четырехъ къ стеб.лю. Листья безхвостые, узкіе, ланцетообразнозаостренные расположенные далеко другъ отъ друга, противуположныя въ основанін стеб.я и вбтвей; въ верху по тріг пा по четыре. Цвьтокъ правп.љный, сідітъ каждыї отды.љьо на тонкой прямой ножкь, выходящей изъ подъ п.чечкковъ каждаго листка и длинне его; по закать солнца онъ закрывается, чтобы съ его появленіемъ раскрыться въ полномъ блескь.

Цвътетъ съ начала мая по сентябрь безпрерывно, посредствонъ вновь появляющихся стеблей и вытвей, которые подъ конєцъ достпгаютъ до двухъ съ половпной Футовъ въ выпшну.

Мнынія на счетъ долговьностп Анагалииса не согласны, иькоторые относятъ его къ двухльтнии, другіе къ многольтнињ, большая же часть къ трехльтНнМъ .

Можетъ быть, это разногласіе пронсходитъ отъ очень бодышаго сходства, которое пщњютъ нногіе сорты, 
приписываелые одному и тому же, хотя они находятся въ разныхъ странахъ, какъ на примьръ: Варварія, IIспанія, Ита.ія ІІ Франція.

Впрочещъ, уходъ за всьни анагалмисами одинаковъ, всь оши льтощъ требуютъ положенія, находящагося въ полутьни, и частой поливкі; знмой содержатся въ оранжере'. Кіронь сьнань ихъ можно разводить еще черенками въ паровой грядкь, находящейся въ тьнш; чрезъ два пьслца они укоренятся и будутъ цвђстп.

Діоскорпдъ (Dioscoride) и П.линій (Pline) хорошо описали Анагалиисъ съ цвьтани красными и голубыли. Ть

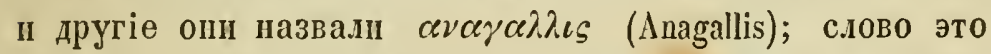
пропзводное отъ предлога ává (апа) и существительна-

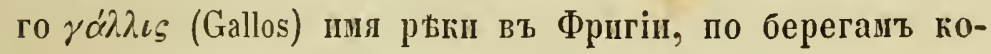
торой Анагалипсы растутъ въ изобнліи.

( (\$o cr. Her. Gen. AE 5.) 



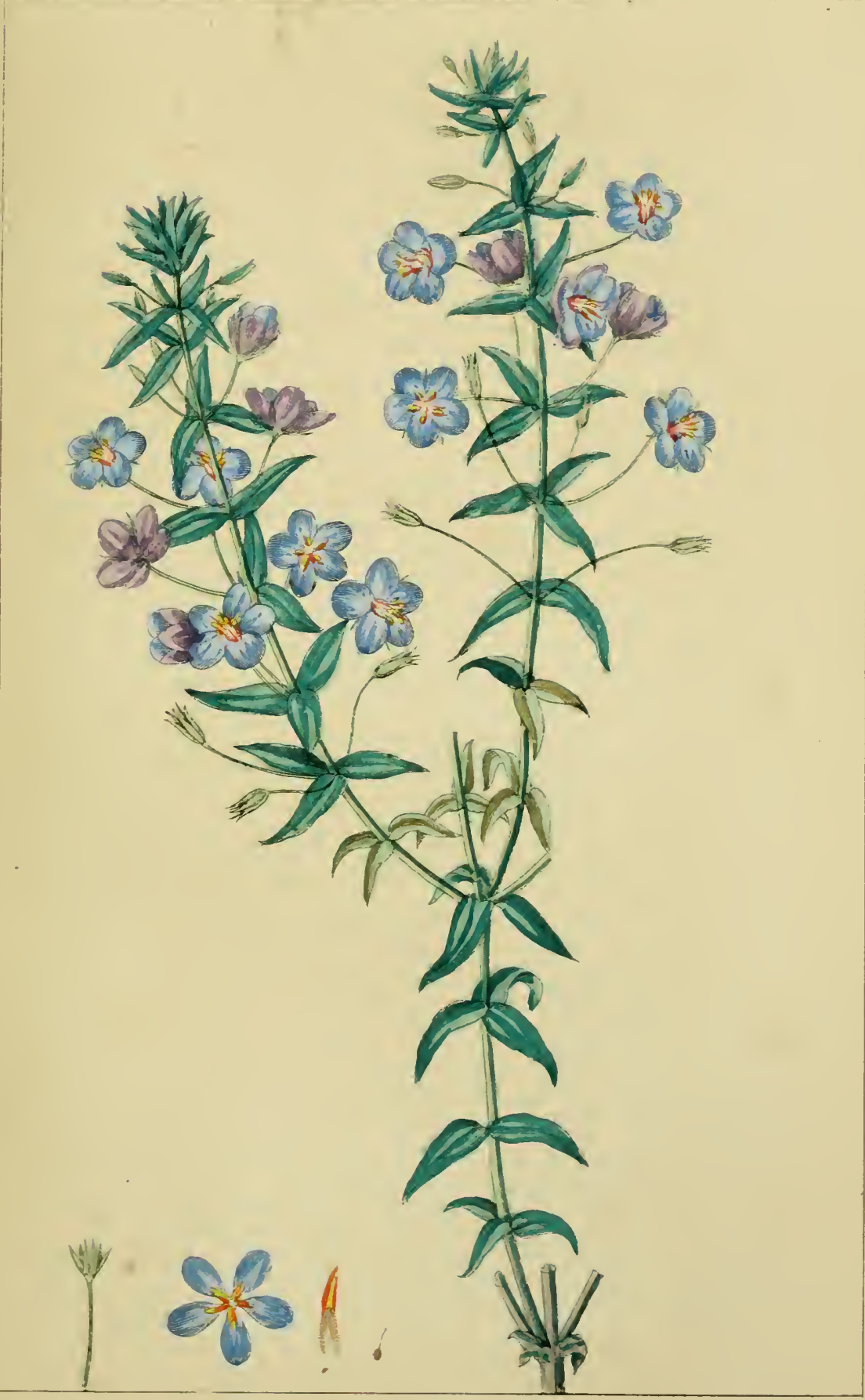

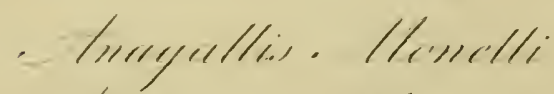

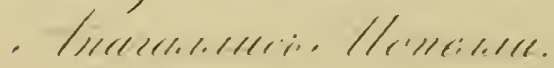





\title{
АРТРОПО ДІУМ' ЦИРАТУМ'Ь.
}

\section{ARTIIROPODIUI GIRRHATUM.}

\author{
IEXANDRIE-MONOGYNIE. \\ Семейство .Іихейнъхъ Liliaceae.
}

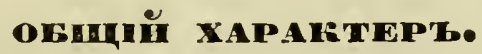

Растенія, принадлежащія къ этому семейству, водятся во всьхъ частяхъ свыта; на высоть горъ и въ низменной почвъ. Преимущественно они разводятся за красоту и запахъ цвьтовъ; луковицы нькоторыхъ употребляются въ пищу.

Между члепами этого семейства есть очень не похожіе между собой. Большая часть травянстые, но есть со стеблемъ древовиднымъ. Почти всь зимуютъ на открытомъ воздухь, но нькоторые требуютъ мьста въ теплиц пли оранжереб. Разннокатся отдыленіемъ.уковокъ, а нькоторые сьняпан. Почва различна: обыкновенный грунтъ, вересковая, тучная или смьшанная.

arthropodium cirrientum. Brown in Curt. Bot. Mag. n. et t. 2350.-Edwards, Bot. Reg. n. et t. 709.-Speng. Syst. Veget 2 p. 87.

llo Фрапқузски, Arthropode vrillé. 
По Ньмецки, Gliederfuss .

Отечество Новая Зеландія.

Артроподіум цирратумъ въ первый разъ цвьлъ во Франіп въ апрыль въ 1826 года у Сельса (Sels), готорый содержаль его въ теплиц'; но теперь воспитываются въ оранжереь.

Цвьтетъ въ Апрьль, требуетъ почвы легкой. Размножается сьмянами или д'ьленіен отрослей.

Корень многольтній, состоящій изт иясистыхъ щилиндрическихъ мочекъ.

Отъ нихъ идутъ листья узкіе, копьеобразные четырнадцати дюймовъ въ длнну; изъ средины которыхъ подымается цилиндрическій обнаженный стебель, въ вышину отъ четырнадцати до двадцати пяти дюймовъ; въ верхней части вьтвистый п снабжепный въ основаніи каждой вьтви копьеобразныпъ листкомъ.

Цвыты былые, сндящіе по два на ножкахъ, имьющихъ въ основани два маленькіе прнцвьтника; верхиій изъ нихъ двураздылыный. Такъ какъ они сидятъ на ввтвъ въ нькоторонъ разстоянін другъ отъ друга, то ІІ представляютъ видъ петелк. Вынинъ однолепестный, пмьющій отгибъ глубоко раздыленный на шесть частей, изъ которыхъ три наружныя копьеобразны, а три внутреннія овальн и по краялъ не ровно округлены. Тычннки въ числы шести замьчательны тынъ, что пиьютъ жилки мохнатыя съ двухъ противуположныхъ сторонъ, посль оплодотворенія свертывающіеся въ спираль. Зародышь овально продолговатый, содержіть трп сьмянныхъ гнездышка. Продолговатый столбикъ и устье обыкновениы.

(Cr. Hen Gen Ma 93). 


\section{AIEUOUT TEILTHKA.}

\section{ANEMONE IEPATICA.}

POLYANDRIE-POLYDYNIE.

Cелейство . Iютиковьху. Ranunculaceae.

\section{OGEGIII XAPARTEPT.}

0дпо изъ самыхт многочисленныхъ семействъ. Распространено по всым частямъ свЈта, пренмущественно же въ Европ'ь, въ хо.подыхъ и уньренныхъ поясахъ. Стебли болыпею частію травянистые, листья разрђзные н.лі составные; чашечка о трехъ или шести листочкахъ; тычннокъ пножество; п.10дъ раз.ичнаго устройства. Въ цв'ьтникахъ это семейство запмаетъ очень видное мьсто.

IEPatra. Nort Cliff. 223.-FL. tab, 610-etc. Trifolium hepaticum. Bauh. pin 339.

По Француски, Anémone hépatique.

IIо Ньмецкі, Dreylappige Anemone.

IIo Aнrsin̆cki, Hepatica or Noble Lirer-Worl.

ПІо Итальянскі, Flagatella; Trinitas; Erba Trinitas.

Отечество Европа. 
Давно это красивое растеніе, въ вышину не болье шести дюймовъ п свойственное щьстамъ гористымъ и осьненнымъ тьнью хьсовъ, было перенесено съ родной почвы во всь сады Европы, га' оно украшаетъ опушки к.умбъ п возвьщаетъ пробужденіе прпроды, зацвьтая одно пзъ первыхъ.

Собраніе трехъ овально-цьлыхъ листковъ, прнближенныхъ оченъ къ цвђтку, такъ что имьютъ наружный видъ чашечки; состав.яютъ от.ичите.льый характеръ этаго вида Анемона отъ прочихъ. Это различіе показалось нькоторымъ ботаникамъ достаточнымъ, чтобы составить особенную разность, давъ ей названіе.

Корни многольтніе, волокнистые, очень разрастающіеся, если ихъ не раздьлять, имьотъ много глазковъ изъ готорыхъ выходятъ въ марть или апрђ.љ нысколько цвьтковъ: красныхъ, голубыхъ п.ии бъ.ыхъ одинакихъ или щахровыхъ, сидящихъ на длинныхъ цилиндрическихъ ножкахъ; они состоятъ изъ шести или осьмп овальныхъ лепестковъ, окружающихъ множество тычпнокъ съ желтыми го.овками. Зародышь безхвостый. Аистья трехъ-.опастные, въ началь очень мохнаты, свытлозеленые, потомъ гладкіе, блестящіе переходящіе въ красный цвьтъ. Размножается дыленіемъ корней и сыманами. При раздьленіи корня надо быть осторожнымъ, чтобы не сдьлать большой раны, а также пристугать къ раздъленіг махровыхъ, когда они отцвътутъ, а одинакихъ по созрьніи сьмянъ.

Махровый съ гохубыми цвьтами, самый ньжный и изысканый; опъ часто пропадаетъ, если будетъ потревоженъ не во время или не будетъ дано настоящее по.ложеніе п зелля, а потому чтобы сохрапить его, надо сажать въ вересковую землю въ мњсть расположенномъ на востокъ. Во время полнаго цвьта, притьнять въ полдепь, отъ этаго цвыты будуть дольше держаться. 
Названіе Анемонъ (Anemone) и печеночный (hepatica), есть производные слова съ греческихъ: $\dot{\nu \varepsilon \mu о \varsigma ~(a n e m o s) ~}$

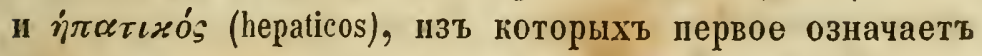
в'теръ а посльдніе, все что пмьетъ отношеніе къ печенп. По словамъ Плинія (Pline), цвьтамъ Анемона нужно дуновенія вытерка, чтобы разкрыться; а дистья, раздЊ.ленные па трі красноватыя лопості, кажутся похожпии на печень; въ то время думалп, что это растеніе пмьетъ свойство излечивать отъ бользни въ печнн'.

Вообще Анемоны требуютъ земл, составленноп: изъ пяти частей рьчнаго песку, трехъ частей хорошей садовой и четырехъ частей совершенно перегнившаго конскаго навозу. Эту смьсь составивъ въ августь, даютъ лежать въ продолженіе года, время отъ времяни помьшивая. Просьявъ насыпаютъ въ мьсто назначенное для посадкі, дюймовъ па пять; подъ этимъ слоенъ, земля должна быть песчаная съ камушками, для того чтобы излишняя влажность, вредная ростенію, могла свободно уходить внизъ.

Въ сентябр'ь сажаютъ Анемоны въ глубнну дюйма на два; и хотя они могутъ зимовать безъ покрышки, но прн нашемъ суровонъ клиать, гораздо безопаснье, при наступленіи порозовъ, прикрывать соломоі, накладывая сверхъ ея сухаго навозу. Ес.іп случится отте. пель, то давать воздухъ, сннмая покрышку.

Весной Анепоны сажаютъ въ апрьль прямо въ грунтъ или посадив' въ марть въ горшки, держать ихъ въ оранжереь или въ комнать въ холоднонъ мьсть въ тьни прнумьренної поливкь; въ концы апрь.ла высаживаютъ и прикрываютъ отъ утренниковъ.

Махровые Анемоны не дають сьмянъ, а ихъ собираютъ съ красивьпшихъ одинаковыхъ. Высною высьваютъ, покрывъ на четверть дюйма просьяною з'емлею; поливаютъ достаточно, потонъ притьняютъ, чтобы зец-

$\Psi_{\text {Aсть II. }}$ 
яа не такъ скоро просыхала. Если не будетъ дождя, то поливаютъ два раза въ недълю, соблюдая, чтобы на лейкь было мелкое ситечко. Когда листья начнутъ завядать, вынимаютъ корни изъ зенли и сохраняютъ до посадки въ сухонъ ньсть.

AHEMTHT HOPOHAPIA. ANEMONE CORONARIA.

Anemone coronaria. Lin. Spec. 760.-Willd. Spec. 2. p. 1276.-Lam. Diet. Ene. 1 p. 165.

По Французски, Anemone á eouronnes.

Iо Нвмецкі, Kronen Anemone.

Отечество: Южная Европа и Востокъ.

Корень шишковатый, тенный; ншжняя часть его даетъ ньсколько мылихъ мочекъ а изъ верхней рождаются лпстья на длннихъ черешкахъ они почти гладки, съ разрьзани болье или менъе ясными, иногда давольно разширенными въ другой разъ узким. Изъ средины листьевъ возвышается стебель, отъ восьли до десяти дюймъ въ вышину, оканчнваясь одниџъ большимъ прекраснымъ цвъткомъ состоящимъ изъ пяти или шести овально-прододговатыхъ лепестковъ.

Разнообразіенъ красокъ этотъ видъ Аненона заслуживаетъ вниманіе любителсй. Хотя къ удивленію рьдко встрьчается въ садахъ напихъ; даже въ дикомъ состояніи разнообразіе это одинаково и особенно въ разныхъ оттьнкахъ цвьтовъ граснаго и голубаго.

Лиственный покровъ расположенъ въ нькоторонъ разстояніи отъ цвьтка состоитъ изъ трехъ безхвостыхъ на трое разсьченныхъ листочковъ. Тычннки короче вьнчика весьма многочнсленны.

Зародыши тоже многочнсленны и заключены въ чашечкъ собранные въ кучку.

Аненонь коронарія ростетъ дико на полих и пажнтяхъ южныхъ частей Фрапцін, Ірованса и Лангедока. 


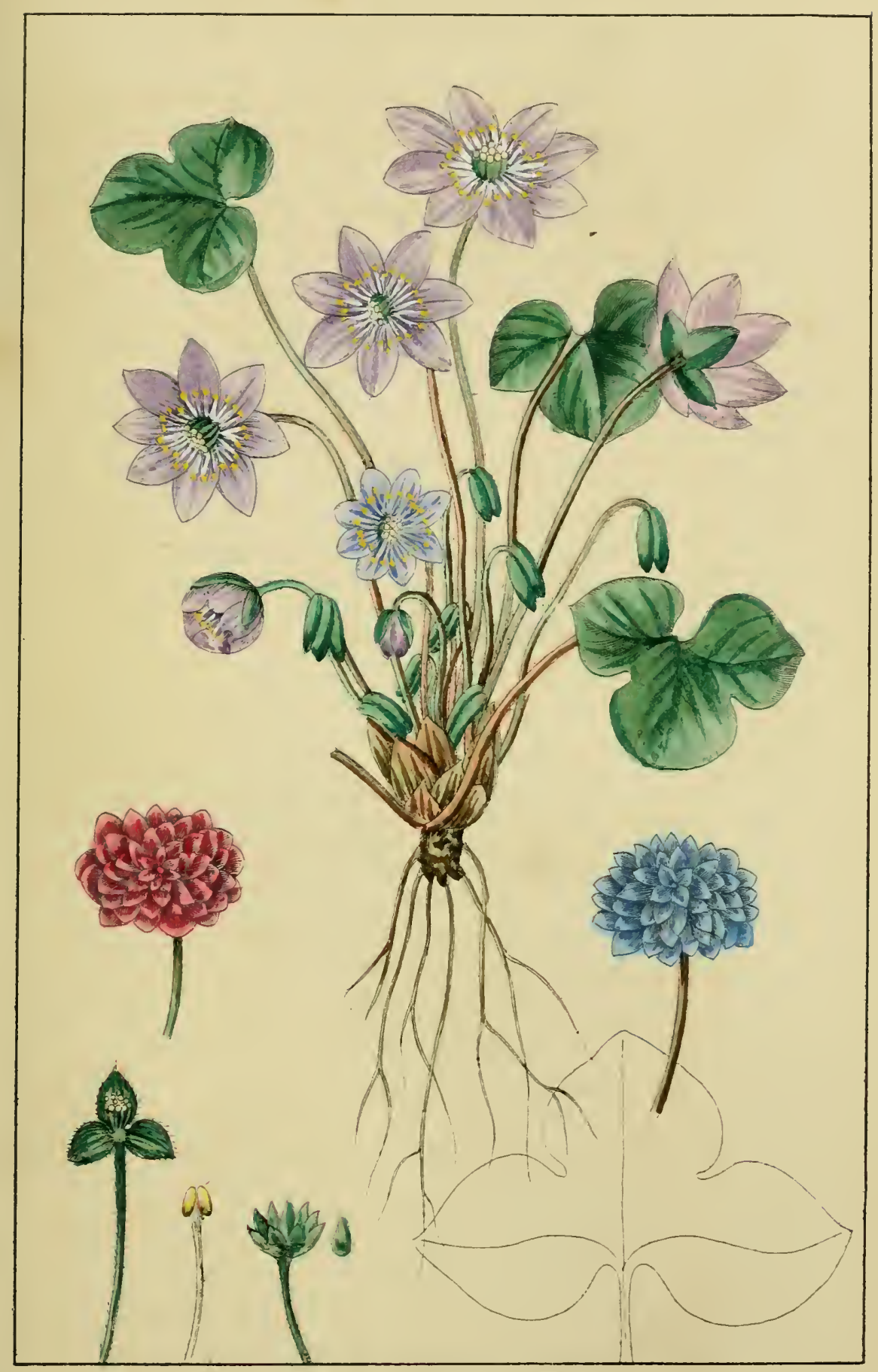

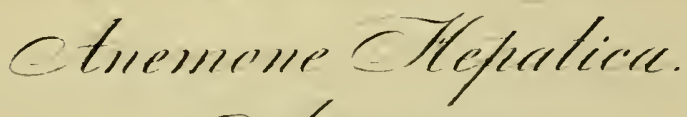

$$
\begin{aligned}
& \text { Etimerrens. }
\end{aligned}
$$



Еще чащ' встрьчается въ Италін, Греціи и въ Леванть. Цв'ьтетъ въ марть и ранье, смотря по теплоть кдимата; въ сьверныхъ әадахъ цв'ьты его показываются въ конц' апр'ья ия въ ма'.

\section{AMENOH' IMAORHHA. ANEMONE PAVOVINA.}

Anemone parovina. Lam. Dict. Enc. 1 p. 166.-Lois. Not. 87.-Decand. Regn. Veget. 1 p. 197.

По Французски. Anemone oeil-de-paon.

Отечество Южная Франція.

Корень шишковатый изъ коего рождаются ньсколько листьевъ почти гладкихъ сидящпхъ на черешкахъ, однг съ треня пли пятью глубокими раздьленіями, слегка разрџзанными въ верху на два или на три скруг.енныхъ лопости, и оканчпвающихся остроконечно; другіе съ разрьзаши уже и глубоко раздыленными на остроконечныя и копьеобразныя лопости.

Цвьточный стебель вышиного отъ восьми до двњнадцати дюйовъ, держитъ на вершинь своей одинъ цвьтокъ, округленный оболочкого изъ трехъ безхвостыхъ листиковъ копьеобразныхъ, цьльныхъ, иногда двураздъ.љьныхъ и даже трехраздъ.ьныхъ.

Выгчнъъ шириного отъ двухъ до трехъ дюймовъ состоптъ изъ десяти или двадцати лепестковъ овальнопродолговатыхъ ярко-краснаго цвьта. Съмячки мохнатые оканчиваютсй острымъ какъ шило и гладкимъ столбикомъ.

Этотъ видъ ростетъ днко во Франціи, въ окружностяхъ Грасса (Grasse) й Дакса, (Dax) гдь часто находятъ съ махровыми цвьтами которые меньше, и лепестки очень узки почти линееобразны.

Анемопы были у древнихъ въ числь растеній вьнечныхъ то-есть употреблялись д.я плетенія вынковъ; но калется что онп дава.и это назване пногим раз.ич- 
нымъ растеніям и нькоторые писате.и думаютъ, qто Анемонъ надобно отнести къ роду Адониса, родившемуся, по словалъ стихотворцевъ изъ крови Адониса.

Анемоны въ чис.ґ⿱ лучшихъ цвьтовъ, но природа не дала им прелестп, пріятнаго запаха. Оттого родилась

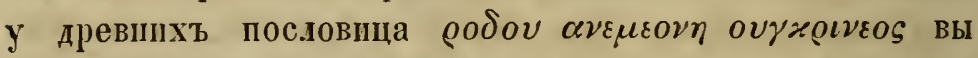
сравниваете розу съ аненономъ, что относнлось къ тыъ, которые ставили въ паралель предметы разнаго достопнства.

Описанные два вида Анемонъ напболье цьнятея любите.ямп и первый нзъ нихъ въ особенпості; вьроятно потому что онъ имьетъ болье другпхъ, свойство пзиьнятея и разнообразиться всякій разъ какъ его разводятъ сьмянами, что пропзве.ло бо.ьшое чис.ло видовъ состав.яющихъ страсть охотниковъ. Уже съ 1660 года на это бы.ло обращено вниманіе любителей. Прежде этой эпохп знали только нђско.ько впдовъ дико ростущихъ на югъ Франціи и Европы. Г. Баше.ье (Bachelier) знаменптый цвътолюбнте.ь Парижа первый привезъ изъ Восточной Индіи пли лучше изъ Леванта, новые впды и гораздо красивыишіе тьхъ которые до него были извъстны.

Есть люди восхищенные тьнъ, что могутъ ниья что нибудь шрекрасное подЂ.ится съ другим: это самое благородное в.еченіе. Но увы! Къ несчастію есть I такіе (а ихъ не мало), которые съ жадностью скупца владъя рьдким растеніемъ не подьяятся пмъ ни съ кыл, какъ собака на сьны въ извыстной всъыъ баснь. Таковъ былъ и Бателье, потому что десять льтъ не дъ.пися ни съ кым вывезенными ищъ Анемонамп. Разсказываютъ забавный анекдотъ выдуманный однимъ совытникоъ парламента; онъ выбралъ время, когда сьмана анемона созрьли и посьтиль Бастелье одьтый въ судейское платье, что допускадось обычаемъ того 
времени. Проходя мпмо столь желанныхъ растепій, онъ ловко опустилъ платье на сьмяна, которые и приста.и къ нему. Лакей его, предупрежденный объ этомъ с.лжилъ внутрь, не давъ того замьтить, то мьсто гды сьмяна присталі. На сльдующій годъ совьтникъ передалъ свое похпщеніе въ руки всьхъ друзей и черезъ нихъ сообщиль его всей Европ'ь.

Съ того времени, старапіями пюбителей, Апемоны подверглись такону множеству пзынепій, что ихъ считаютъ теперь болье трехъ сотъ видовъ, которые различаются по цвьту и раздыляются па классы йл семейства, какъ то пурпуровыя, крануазинныя красныя, телесныя, бьлыя, голубыя, фіолетовыя темныя полосатыя въ пятнышахъ. Здысь разульотся только Анемоны махровыя, простыя же, которыя вообще не очень цьнятся любитедями, хотя пюьють цвыта блестящье и живъе, составляютъ особенный родъ, который называется Анемонъ маковыи.-Красивые Аненоны должны имьть: дистья (pampre) толстыя, красиво вырьзанныя, лркозелешыя. Покровъ (fаnе) также какъ и листья красивой вырьзки, долкенъ отстоять отъ цвьтка по крайней пьрњ око.ло третп длины всего черешка (baquette) который долженъ быть высокъ, прямъ, твердъ, чтобы держать цвытокъ не сгибаясь подъ его тяжестьо. Цвьтокъ въ поперечникь долженъ имьть ие ненье трети дюйма, хорошоокругленъ, цвыта живы и глянцевиты. Наружные депестки (manteau) толсты, закруглены; внутренніе непосредственно сльдующіе за наружными, должны быть коротки, широкн. закруглены а главное другой окраски; салые же внутренніе то-есть превратившіеся изъ пестиковъ (bequillons) и образующіе самый кружекъ (cercle), должны быть многочисленны, не очень заострены и нъсколько удлинены, такъ чтобы весь цвытокъ представляль болье или менъе гладкую округлость.

Анемоны никогда не оставляются два года сряду въ 
земль; очень хорошо имьть двойной коплектъ, чтобы по.овина отдыхала годъ. Перепьна почвы есть также средство сохранить видонзмьняемость во всей крась ея.

Но унножая сьиянами можно только пріобрысть новыя пзмьненія.

AHEMOHT ATEHHHA. ANEMONE APENNINA.

Anemone apennira. Lin. Sp. 762.-Willd. Sp. 2 p. 1282.Curt. Lond. fasc. 6. t, 35.-Smith. Fl .Brit. 2. p. 581.

IIo Французски Anémone dn l'Apennin.

По Ньмецки Apenninen Anemone.

По Англійски Blue mountain Anemone.

По Итальянски Anemono Apennino.

Отечество Италія.

Этотъ видъ Апемона извьстенъ очень давно; всь ботаники среднихъ вьковъ о немъ упопинаютъ и рисунки его находятся у Клюзіуса (Clusius) Додонауса (Dodonaeus) Лобеля (Lobel) Далешана (Dalechamps) и многихъ другихъ, трое посльднихъ изъ упоминаемыхъ писателей только списали у перваго. Клюзіусъ сообщаетъ что въ его вреня этотъ Анемонъ воспитывался въ садахъ Белгіи, гдь' онъ былъ размпоженъ стараніями Ивана Бранціөна (Jean de Brancion) поторый первый получилъ его изъ Итахіи отъ Альфонса Пантіуса (Alphonse Pantius) доктора герцога Феррарскаго.

Неизвыстно откуда онъ былъ вывезенъ въ Парижъ, изъ Белгіи ли гды онъ былъ разведенъ первоначально пли пзъ Англіи гд" растетъ патурально, илі съ горъ ІІрованса гд' говорятъ онъ также находится, нли наконецъ пзъ самой Итахіи первой его колыбели, рышить очень трудно, впрочемъ и безполезно разыскивать.

Размножаетсл дыленіемъ корня осенью и тотчасъ сажается потому что внь земли опъ не можетъ такъ хо- 
рошо сохранится, какъ прочіе виды ихъ. Земля дается преимуществено вересковая.

Корень шишковатыи толщиною въ палецъ, горизонтальный пзогнутый, черноватый съ наружи. Листья покрыты пушкомъ особенно по краямъ темновато-зе.леные, вдвойнь тройчатые, сидящіе на длинпыхъ черешкахъ обыкновенио ихъ бываетъ два нли три. Цвыты очень красивы, внутри голубые, снаружи свьтло-лиловые, состоящіе изъ двьнадцаті пли двадцати узкихъ лепестковъ; распускаются въ марть или апрьль. 

गाT
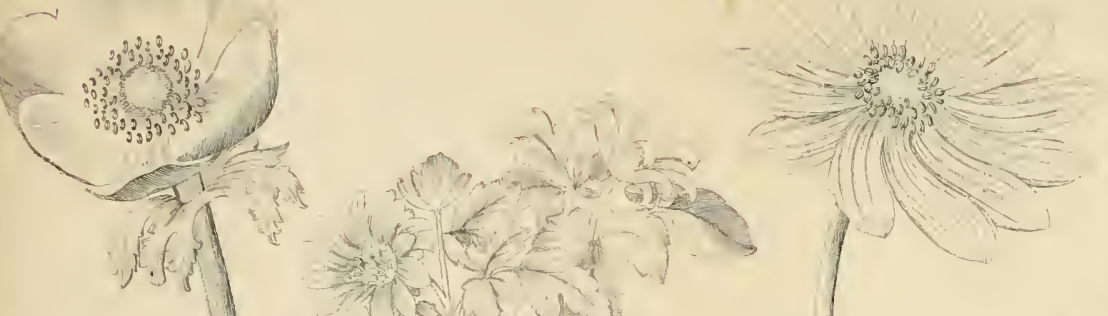
$+1) \cdot 3$

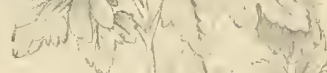

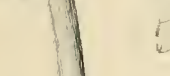




\section{(1) TA A I}

В Т О Р 0 Й. 



\section{АКАЦН ФАІЬКАТА.}

\section{AGacha FalGata.}

POLYGAMIE-MONACCIE.

Семейство Бобовъхху, Leguminosae.

Acacia falcata. Willd. Spec. 4 p. 1053.

По Французски, Асасіе en faux.

Акаціа фальката растеть деревцонъ, достпгая восьми или десяти футъ въ вышину. ВБтви переньнно сидящіе гладкіс, безъ пголъ, прегоднятые съ двухъ противуположныхъ сторонъ. Лпстья попереиьнно сидящіе, продолговатые, неправильно зазгнутые, въ основаніи очень съ уженные, оканчпвающіеся въ верхней части остріемъ; покрыты жилкани, пересьченными по средннь неровной жилкой. Цвъты бльдно-желтые очень маленькіе, сидящіе на ножкахъ, шарообразные, соединены отъ пятнадцатп до двадцати и расположены кпстямп, выходящими изъ подъ плечнковъ листьевъ, и на кондахъ вытвеі по двь и по одной иистн. Нижняя часть цвЊтка одноліственна, о пяти зубчнкахъ. В Бнчикъ тоже однолиственныи. Тычинки очень щногочисленны. 


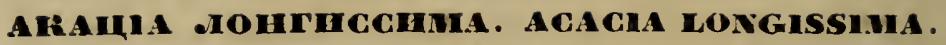

Вьтви почти трехъ угольные; листья въ д.лину до восьми дюймовъ; цвьты желтые въ колосьяхъ.

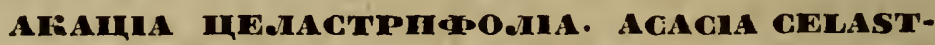
RnFona. Растеть очень красивып вбтвистымъ кустарникомъ, достигая сещи Футъ въ вышин; дистья сьрозеленые цвыты благовонные, расположенные на концахъ вътвей красивыми болышип кистями.

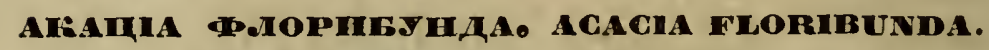

Кустарникъ достпгаюій шести футовъ въ вышину, съ пониши.п в бтвями; листья длинные, заостренные, раскошно покрывающіе кустъ; душистые сьрожелтые цвъты распускаются весного на подобіе кодоса, по два п потрі вмьсть.

\section{ARALIA MIPTHAOMIA. ICACHA MTRTHOLA.}

Листья продолговатые, заостренные съ толстыми краямп; цвьтовъ не шного они желтые маленькіе, шарообразные.

\section{ATALIA MATHOOO.ILA. ACACIA LATHFOLA.}

Листья на подобіе серпа, пепельно-сьроватые; цвбты блыдно-желтые, очень маленькіе, шарообразные, распускаются въ апрьль или маь, небольшими кисточкащи.

ARALIA CEMIIEPATOPEHCTO ACACIA SEMPerfeorens. Стебель прямой въ вышину отъ четырехъ до шести футъ; вытви раскинуты; листья продолговато-ланцетообразные, сьрозеленые; цвыты маленькіе душистые, желтые, шаровидные, расположены кистил.

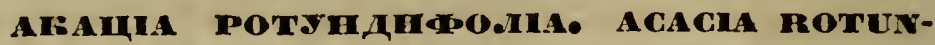
miсоца. Развьспстое деревцо, въ вышину по четырехъ футь; листьд округленные, тупые слегка въ водоскахъ. Цвыты золотистые многочисленны, расподожены шаровидныни го.овкани, перешынаны съ листьян. Если деревцо предоставить расти на собственный про- 
изво.ъ, то оно представ.яяетъ непріятный видъ, напротивъ будучи развязано по решеткь очень краспво.

ARA HIA DEITOHEY PA. MCACLA LEPTONEURA. Кустарннкъ раскідистый, вырастающій до пяти футовъ въ вышиу. Вытви тонкія, гиокія, покрываются въ апрђль желто.оранжевыми шаровидными цвђтами; листья почті нітеобразны, пзкривлены, отъ двухъ до трехъ дюймовъ длины. Если сиотрьть на нихъ въ увелпчн те.ьное стекло, то они кажутся въ длину слегка струйчатые.

\section{ARAMLA CTPIIRTA. ACACHA STRICTA.}

Вьтви гладкіе; листья длпные узкіе, въ верху тупые и.и съ зубчиками; цвъты очень маленькіе, желтые спдящіе по парио. Мьсто дается въ оранжереь, такъ чтобы растеніе стоя.іо въ полу-тьни.

Отечество опнсанныхъ впдовъ Акацій Новая Голландія.

Всь они требуютъ вересковую землю; льтощъ могуть выставляться на воздухъ, зимой содержатся въ оранжереь. Размножаются отводками, но препнущественно съмянаяи сохранающпи силу растительности, въ продолженіи нысколькихъ льтъ.

Съмена нькоторыхъ сортовъ бываютъ такъ тверды, что предъ посадкой надо мочіть два или три дня или съ боку слегка надрьзать кожцц, отъ чего гораздо cropte взоп̆дутъ. 


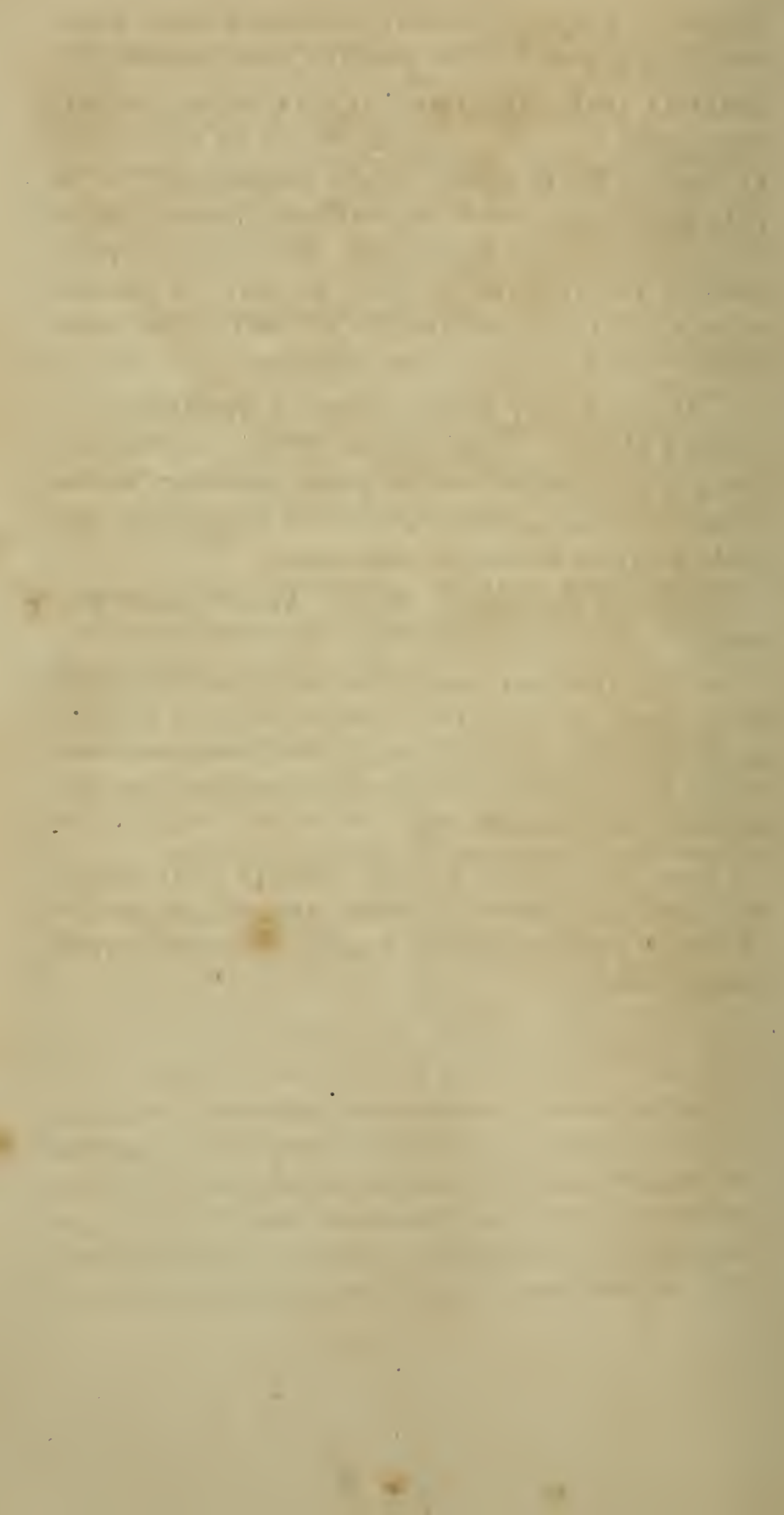




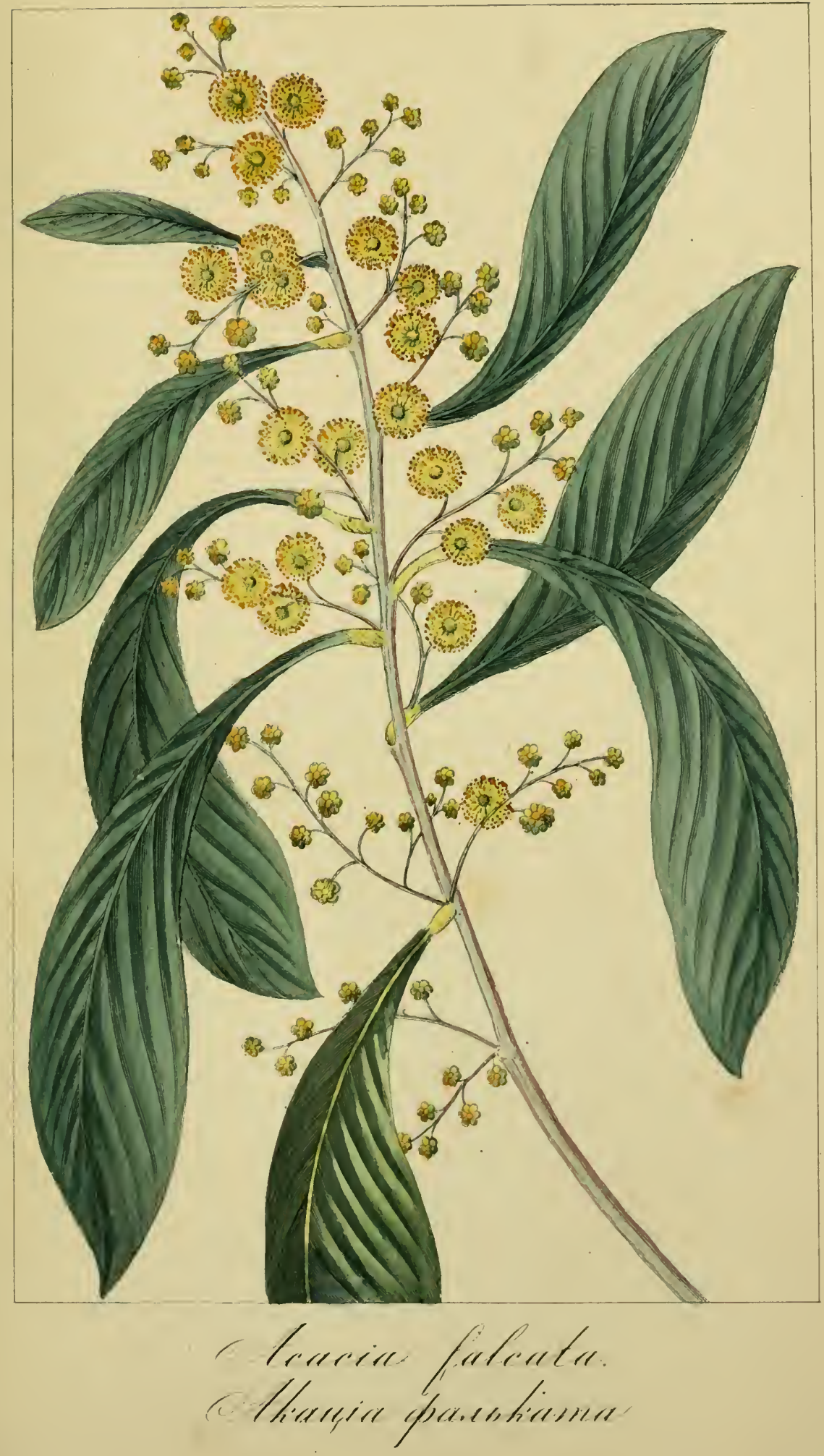





\section{AXPACG GAIIOTA. ACHRAS SAPOTA.}

NEXANDRIE-MONOGYNIE.

Cемейство Canomoвъхъ Sapoteae.

\section{OEVRIIII XAPAIETEPT.}

Семейство составленное большего частію изъ тропическихъ фруктовыхъ деревьевъ.

По Фрашцузски, Sapotilier commun.

Олечество 0. Аитильскіе.

Сапота нлн какъ называютъ въ простонародіи Запота, состав.яетъ одно изъ самыхъ интересныхъ деревъ, находящихся иа 0. Антильскихъ. Въ вынину иа родии' доходитъ до сорока фунтовъ, принияая большею частію пирамндалную форму. Вьтви покрыты бурой карой и украшены въ верху овально-копьеобразными, г.ладким, темнозеленым, глянеевтыми, листьям, остроконечными съ обонхъ концевъ. Колакольчатые бъ.лые цвњты не очень красивы, сидятъ отдђ.льно или иа концахъ вытвей. Выпчикъ бы.ый раздъ.леный въ отгибъ па шесть разрьзовъ; подъ каждымъ изъ нихъ, находится кожнца зубчатая въ верху. Тычинки въ чис.лы шести иньотъ очень короткіе нитп, сжатые въ трубочкы вьнчика, головки тычинокъ стоящіе прямо, почти остроугольны. Зародышь овальный, сидитъ въ мяспстоиъ мохнатомъ железновиднонъ кругт; сверхъ зародыша нахоАптся толстый продолговатый столбнґ, постепенпо съуживающійся и оканчивающійся тупым устьемъ. Плодъ 
янцевидный или округленный величиною съ яблоко, одииъ изъ лучшихъ въ Амерікь, кожица, его покрыта, какъ бы железновидной пылью, внутренность состоитъ изъ сочнаго тьла, заключающаго въ срединь, десять зерень, черныхъ продолговато-сжатыхъ блестящихъ. На родины цвыты начинаютъ показыватся въ маъ, въ продолженіи трехъ или четырехъ мысяцевъ.

Первые плоды поспьваютъ въ сентябры потомъ посльдовательно до генваря.

Въ незрьломъ состояніи, плоды имыютъ вкусъ терпкій, молочный; по мьр'в созрьванія постепенио переходящій въ сладкій и сочный, такъ что въ совершенпо зрьломъ, стаповится даже приторныпъ. Такъ какъ дерево можетъ приносить плоды, достигнувъ десяти или двњнадцати л'тняго возроста, то по этому они дороги. Растущіе близь города щедро вознаграждаютъ за уходъ и долгое ожидапіе; нербдко одпо дерево приносить плода на дв'ь или три тысячи франковъ.

Если сломить молодую вытку нли листъ, то изъ сломаннаго мъста выступаетъ молочная липкая жндкость, густьющая па воздухь и превращающаяся въ бьлую смолу, издающую при гореніи запахъ ладона. Сокъ изъ косточекъ употребляется въ медпцинь. Дерево довольно гибко и крыпко; употребляется при внутрениихъ постройкахъ въ домахъ; для наружныхъ же не годится, такъ какъ не можетъ переносить сырости.

Лгбитъ зенлю легкую глубоко-разрыхлевную. Размножатся отводками, но еще лучше съиянами въ теплицы, гды растеніе сажается въ землю составленную изъ двухъ частей чернозема, одной трети торфа.

На родинь избьгають сажать его близь домовъ, потому что утромъ или посль дождя, онъ издаетъ вредный запахъ, уничтожающійся посль восхода солнца.

(Cr. Flore des Antilles par M. de Tussac 1 p. 73 t. 5.) 


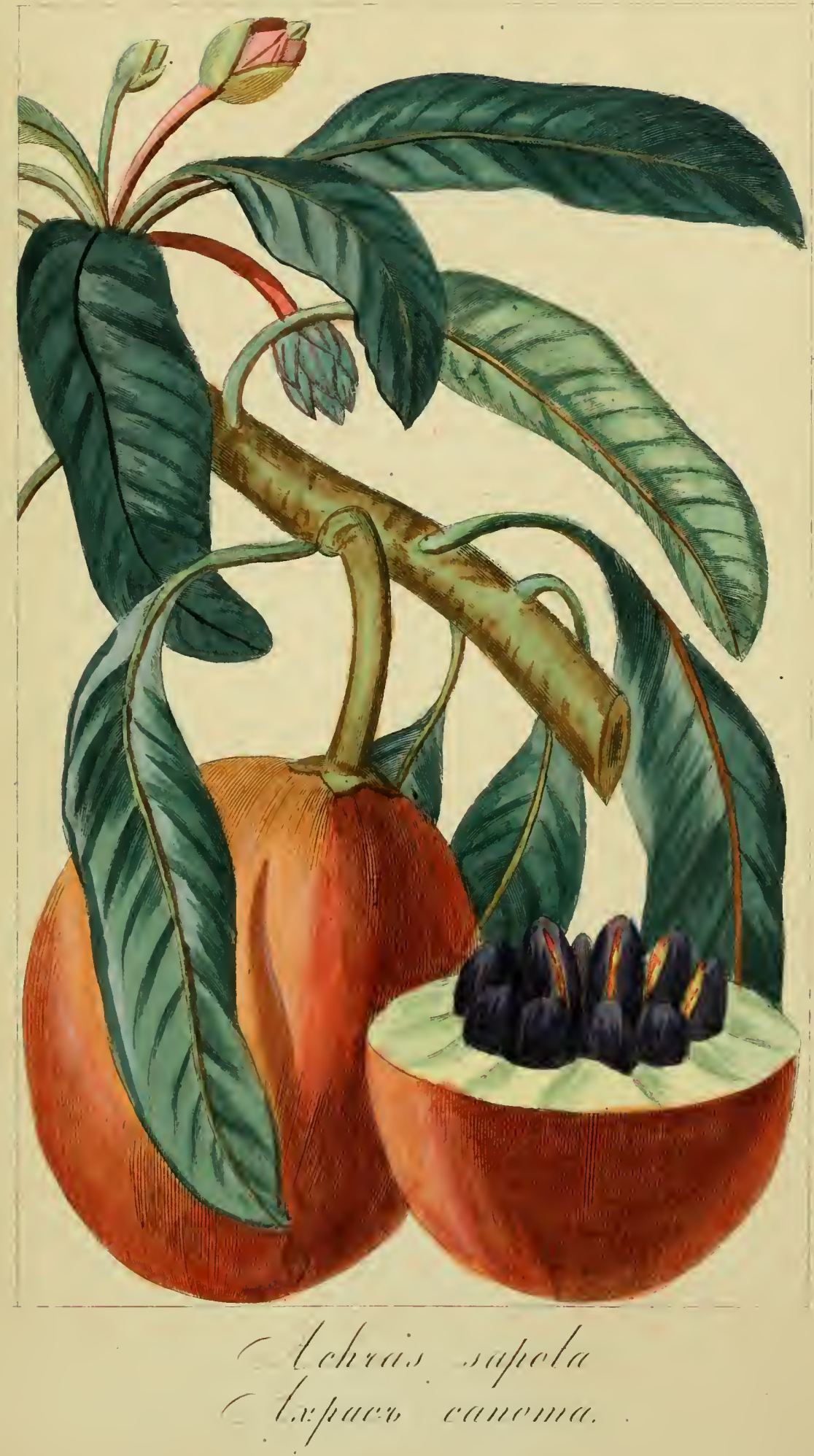





\section{АТРАЯЕНЕ ИНДИКА.}

\section{ATRAGENE INDIGA.}

POL YANDRIE-POLYGYNIE.

Cелейство .Іютиковъхх. Ranunculaceae.

Atragene Indica. Desf. Catal. Hort. Par. 145.

ПІо Французски, Atragene des indes.

Поо Ньмецкі, Waldrebe.

Отечество Японія.

Атражене индика очень мало отлиается оть Клематиса (Clematis), такъ что многіе ботаники соединили ихъ въ одинъ видъ. Однако Линней разъединилъ, и нькоторые ему сльдуютъ. Тунбергъ оппсалъ этотъ кустарникъ подъ имянемъ Клематиса. (См. Clematss florida Tunb. Fl. Tap. p. 240).

Въ Европ'ь это растеніе извьстно съ 1776 года и содержалось въ теплиц; но теперь или потому, что оно акклиматизировалось, или что само по собь не требуетъ высокой температуры, зимой содержится въ оранжереъ. Почва черноземъ по поламъ съ вересковой и теплое сухое мвсто.

YACTB II. 
Чтобы ранье зацвьлъ приставляютъ ближе къ свђту. Во время цвыта надо притьнять отъ десяти до двухъ часовъ, отъ этаго цвьты будутъ кпупнъе и дольше держатся. Цвьтетъ съ мая по сентябр. Размножается легко отводками. Стебель почти съ самаго основанія раздьленъ на ньсколько гладкихъ, цьпкихъ вытвей. Листья гладкіе, противуположные, сидящіе на черешкахъ, овальные или овально-копье образные, обыкновенно цылые, очень ръдко зазубренные; листовая ножка обвивается около вытвей деревьевъ находящихся близь ростенія и такимъ образомъ оно пожетъ цыпдяясь поднятся на доводьно значительную высоту.

Цвъты крупные, въ ширину около двухъ съ половиной дюймов'ь, сначала зеленоватые, потомъ бълые, сидящіе на длинной цвђтной ножкђ, по срединь которой находятся два противуположныхъ листочка, цылыхъ или трилепестныхъ. Нижняя часть цвђтка состоитъ изъ шести большихъ овальныхъ листочковъ, остроконечныхъ и бъловатыхъ.

Вънчикъ въ одинаковыхъ цвьткахъ, кажется состоящимъ изъ двьнадцати или двадцати лепестновъ. Тычинки очень многочесленны. Въ махровыхъ же цвьткахъ, всь тычинки и продожговатый стебель, изыьняются въ иножество овально-продолговатыхъ лепестковъ, остроконечныхъ въ верху, съуженныхъ въ основаніи. Въ самой срединь не находится болье ни какихь признаковъ другимъ сльдовъ, ростительности.

(Cm. Her. Gen. 1979. 


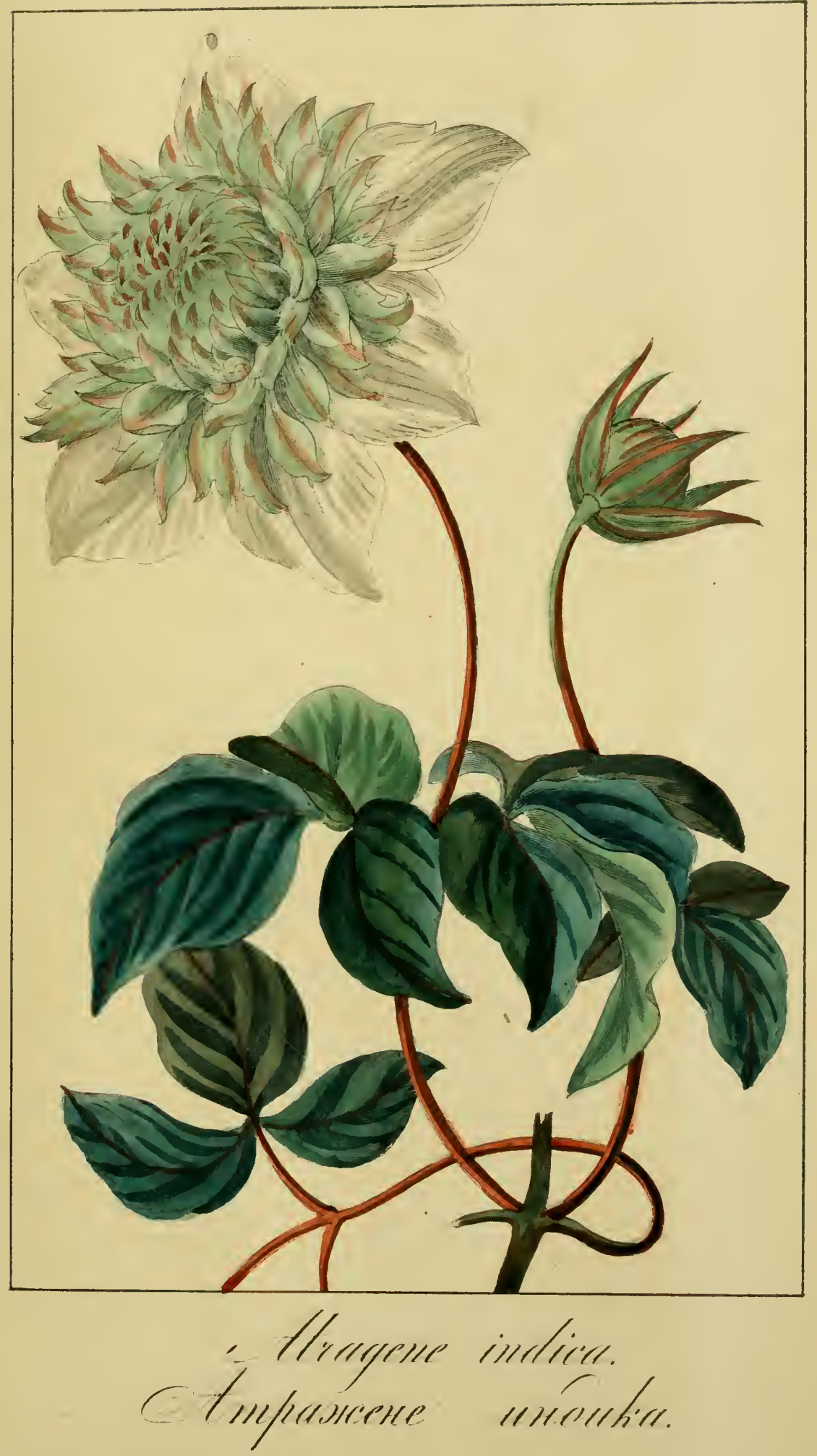



(1) I

T P E T I Й. 



\section{ГPHБЫ. FUNGI.}

\section{OEщцй XAPAKTEPT.}

Семейство составляющее растенія чрезвычайно разнообразнаго вида; произрастаетъ почти на всякой почвђ; въ льсахъ, на лугахъ, въ садахъ; густая трава нли мЂлкій кустарникъ большею частію препятствуютъ провзрастенію нхъ.

Нькоторые породы грпбов'ь, какъ напримьръ: трюфель, ростутъ подъ зем.ею; другіе изъ гиіющаго дерева плю на древесныхъ стволахъ и корнахъ; онн никогда не жнвутъ подъ водою, но нерьдко на поверхностп жндкостей; требуя для своего развитія болье тепла нежели свьта. Сьмена грибовъ подобны тончайшей пыли, лежатъ инутри ткани ихъ или на поверхности. Въ Европь считаютъ отъ двухъ до трехъ тысячь породъ. Нькоторые почти вовсе не замьтны д.я простаго глаза, напримьрь: Ржавченные Uredineae, пми Пльсневые Mucedineae другіе напротивъ бываютъ давольно большихъ размьровъ, рьдко впрочеиъ достигающихъ болье фута въ поперечникь. Очень многіе изъ грнбовъ растутъ быстро ІІ жизнь ихъ можно назвать мгновенной, другіе же напротивъ растутъ І жівутъ очень долго. Въ чпсль грнбовъ очень много ядовитыхъ. Весьма немногіе породы грнбовъ, пменно ть изъ которыхъ приготов.1яютъ трутъ, могуть переносить сухой жаръ или суровый 
холодъ. - Линней да.ı названіе немногимъ грибамъ; бо.ьшія же части ихъ наименованы профессоромъ Фрнсомъ (Fries) или Персономъ (Persoon) изджшищ въ 1801 году первое хорошее сочиненіе о грибахъ вообще, подъ заглавіемъ: Synopsis methodica fungorum. Естествоиспытатели: Албертиии, Бачь, Бюйларъ, НІе феръ и Швейницъ также дали названіе ннсгинъ грибамъ; другіе, какъ напримъръ: Гайне, Гертвпчъ, Кромбогольъ, Крапфъ, Витадини, Вейнманъ, Летелье, Рокъ, Фебусъ, Траттннкъ ипроч. занимались наблюденіемъ надъ ними не изобрбтая названій. 


\section{УПОТРЕБЛЯЕМЫЕ ВЪ ПИЩУ.}

\section{НІІАППИНЬОНТ, ПЕУЕРНЦЦ.}

Agaricus campestris-Lin:-Agaricus edulis-Bull - Agaricus arvensis-Schäf. Agaricus cretaceus. Fr.

IIо Франщузски, Champignon des bruyèrs, champignon boule de neige; champignon de couche; champignon cultivé.

По Нъмецкн, Gemeine champignon; Gugemuke, Feldehramm; Feldbletterchramm; Herrenschvamm.

IIо Англійски, Common Mushroom.

ПІо Итальянски, Pratiolo.

Отечество въ Европь повсемьстно.

Такъ какъ шампиньонъ составляетъ предметъ выгодной торговлі, то его разводятъ искусственно: въ простенкахъ оранжерей, въ парникахъ, въ сухихъ погребахъ и на открытомъ воздухъ.- Чтобы имьть шампнногы рано весной пли поздно осепью, для этаго в’ь простенк'́ оранжереп, нии гды ее н'тт, то и вь погребъ, кладутъ конскаго крупнаго навозу толщиною въ футъ, па него насыпаютъ на четьре дюйма навозной земли; (изъ старыхъ парниковъ); потоиъ опять слой навозу и зелли; и такпя образонъ накладывають ньсколько слоевъ. Вспкій новый слой долженъ быть уже предшествовав- 
шаго. такъ чтобы подъ конецъ образовалась изъ грядки двускатная крыша. Съ боковъ уг.аживаютъ и убиваютъ лопатою, п покрываютъ соломой ежели грядка подвержепа дьйствію свьта или сквознаго вьтра. Ежели навозъ сухъ, надо время отъ времяни спрыскивать. Попрошествіи ньсколькихъ дней грядка нагрьется, что ножно узнать просто палкой, которую воткнувъ въ грядку держать ньсколько времяни, если теплота ее по вынятін ощутительна, то это служитъ признакомъ, что грядка нагрьлась. Пос.љ этаго по бокамъ ее дБлаютъ рукою ямочкі, па.ьца въ три ширнны и такой же г.убины въ разстояніи одна отъ другой дюйма на два или на тріг. Въ каждую изъ этихъ ямочекъ кладутъ грибницы (такъ называютъ семяна грибовъ илі ихъ зародыши) и засыпаютъ вынутою землею. Если по пропествіи ньсколькихъ дней бълевые волокна не выходятъ; то эти мьста вынилаютъ и тотчасъ замьняютъ новыми. Если же посадка хорошо прпнялась, то оставляютъ еще отъ шести до восьми дней, чтобы дать вреия волокнамъ грибницы опутать даже вершину грядкі; посль чего бока ее слегка придавливаютъ ладонью и посыпают́ всю поверхиость на полтора дюйма очень мьло про съянной землею и углаживаютъ лопатой. Если грядка суха непрещьнно нужно поливать.

Мъста изъ которыхъ будутъ вынуты шампиньоны, засыпаютъ мьлой землею. Сборъ ихъ можетъ простиратся отъ четырехъ до пяти пьсяцевъ.

При воспитаніи въ парникахъ, поступают'ь сльдующимъ образомъ: въ парниковые ящики кладутъ свьжій конскій навозъ въ вышину отъ трехъ до шесті дюймъ, слегка предавливая и защищаютъ отъ мокроты II свободнаго доступа свъжаго воздуха; оставляется до тьхъ поръ, пока покроется бълою нитеобразной ткапьо тогда насыпаеть дюйма на два хорошей парниковой зем- 
дею и держать отъ 10 до 14 градусовп тепла. Если сверху насыпанная зем.я суха, то ее слегка поливаютъ простою водою или настоенной на навозђ. Хотя въ приготовленныхъ такияъ образомъ парникахъ шанпиньнны родятся сами собою; но гораздо лучше если можно достать изъ саду илі съ поля такой зенли, на которой уже росли шампиьоны и класть эту зем.лю вщьсть съ находящеюся въ ней грибницею на навозъ.

Время года не имьетъ на это ни какого особеннаго вліянія. Чтобы не мьшать произростаніг грибовъ, никогда не должно вырывать ихъ съ корнемъ, но срезать ножепъ; равнымъ образомъ полезно всь очистки ихъ остающіеся въ кухн' раскидывать по грядамъ, также можно время отъ вренени оставлять на грядахъ ньсколько шампньоновъ, чтобы они тамъ истльли. Всь другіе грибы, появляющіеся въ этихъ парникахъ, вынимаютъ виьсть съ окружающею ихъ землею и выбрасываютъ. Когда шампиньоны шерестали уже выростать въ приготовленныхъ такипъ образощъ парникахъ, то должно пересаживать изъ нихъ грибнцу въ новые парники.

Выращеваніе шампиьоновъ на открытошъ воздухь, очень просто; въ тьнистопъ пьсть дылаютъ грядки отъ двухъ до трехъ футь въ вышину изъ лошадинаго навозу бывшаго уже въ парникь, но сохранившаго хотя небольшую степень теплоты и на него насыпаютъ грибницу виьсть съ землею, потомъ этотъ посьвъ слегка поливаютъ п грядку покрываютъ соломой пли рогожей; покрышка эта необходима, нначе грядка ножетъ скоро просохнуть или слишкоиъ увлажится отъ дождей а г.лавиое будетъ подвержена вліянію свьта, что препятствуетъ росту шампниьоновъ. Чрезъ десять пил четырнадцать дней можпо собирать грнбы повторяя сборъ чрезъ каждые четыре дня, онъ прододжается отъ двухъ до трехъ 


\section{6}

иьсяцевъ. Можно ускорить ростъ шампнионовъ, поливдя грядку слабымъ растворомъ селптры также хорошо поливать помоями отъ шампнноновъ; при поливкь теплой водой они будутъ крупнье.

Для сохраненія шампіоновъ на долгое вреля высушиваютъ ихъ, толкутъ въ порошокъ, и сберегаютъ его въ сухонъ щьсть, чтобы онь лучше сохранили свой запахъ; употребляя его для приправы къ соусамъ.

Грибницы для обсьмяненія шампньонныхъ грядъ собираютъ обыкновенно въ августь или сентябры на тучныхъ мьстахъ, гды шампиньоны родатся сами собою, на пастбищахъ или гдњ долго гиили навозныя кучи. Собравъ тщательно переносятъ на приготовленныя гряды пли сохраняють до употребленія какъ сьмяна въ сухомъ и защищенномъ отъ морозовъ мьсть; грибница можетъ сохранять производительную силу отъ одного до двухъ льтъ; главное вниманіе падо обрашать, чтобы она не подвергнулась вліянію сырости. Можно приготовлять ее и искусственно; для этаго въ марть берутъ по ровной части овечьяго и лошадинаго свьжаго навозу и въ двое коровьяго. Оставляютъ ихъ пока совершенно высохпуть, тогда размельчаютъ и просьвають сквозь рьдкій садовый грохотъ, потонъ хорошенько перемьшиваютъ и подъ навъсомъ ссыпаютъ въ круглую заостренную кучу, оставляютъ такъ пока ога нагрџется тщательно наблюдая чтобы теплота была не менъе восьми или не болье двњнадцати градусовъ. Въ случањ если куча долго не нагрьвается, надо ее покрывать конскимъ соломистымъ навозомъ или просто соломой. По прошествіи пьсяца въ этой кучь появляются бълые пьжные волокна, что показываетъ, что грибница для рощенія шампиноновъ готова. Въ противномъ случаћ кучу снова покрывають павозомъ или соломой. Время появленія грибницы различно пногда она погазываетса 
черезъ три недьл, а пногда черезъ три мьсяца, эта большая разпица врехени происходитъ отъ свойства и состоянія навоза а также и отъ многихъ атмосферическихт явленій, говорятъ, что будто частые и продолжительные грозы, препятствуютъ образованію ея. Другой способъ состоптъ въ сльдующенъ: спьшиваютъ свьжій конскій навозъ не бывшій еще въ кучь п который не прьлъ, съ землею изъ подъ старыхъ навозныхъ кучь. и смьсь эту складываютъ подъ павьсонъ мъсяца на два; посль чего зарождается грибница. При этомъ тоже надо наблюдать за теплотой, какт было сказано выше и за устраненіещ в.іянія свьта на кучу, почену и надо закрывать ее сухою соломой; такъ же пе должно сильно утаптывать.

Описываемый видъ шампинона имъетъ сльдующіе прнзнаки, шляпка и ножки заключаютъ въ себъ чистую бъдую мякоть, иногда съ красноватымъ или буроватыщъ отливомъ, мякоть эта не вязка II не губчата, запахъ и вгусъ пріятныи; ножка снаружи и внутрп бьлая гладкая плотиая, большею частію сплошная безъ влагалища, но съ кольцонъ, длинсю отъ половины до двухъ дюйновъ и болье, толщиною отъ четверти до дюйна, кольцо бьлое.

Шлякка бълая, у самыхъ молодыхъ шампиьоновъ почтіг шаровидная, потомъ д'лается плосковато-выпуклою и наконецъ почти совершенно плоскою, ширнною отъ одного до пяти дюймовъ; поверхность ее суха, пьсколько шелковиста, гладкая или покрыта пелкими чешуйкамп; макоть шляпкг чисто-бълая иногда съ красноватыль отливонъ плотная, нъжная толщиною до половины дюйма. Пластинки чисты, концами свопи едва касаются ножки или вовсе пе доходятъ до нее, у мододыхъ шампиньоновъ былы, но обыкновенно прежде чьњъ край ш.япки отдьлится отъ ножки, онь прнни- 
маютъ б.Аднорозовый цвьтъ, у старыхъ д'ьаются краснобурыми а при увяданіи гриба почти черными.

Прн собирапіи болье всего должно обращать вниманіе на бълуг мякоть; ножку съ бълымъ кольцомъ и на розовый цвьтъ пластинокъ. 


\section{CMOPУERТ ОБЫКНОВЕННЫЙ.}

\section{MORGHELLA ESGULENTA.}

По Французски. Morille ordinaire, Morille des ragouts.

По Ньмецкп. Gemeine Morchel, essbare Mochel, Sumpfmorchel, essbarer Zellschwamm. Murche, Morgel, Maurachen.

По Англійски. Morel.

Отечество: Европа, Азія и Свверная Америка.

Растетъ весной, особенно во время сырой теплой погоды, весьма изобильно; въ льсахъ, по полямъ и на гористыхъ мьстахъ преимущественно съ известковымъ или глинистымъ грунтомъ; также попадается въ изобиліп на тьхъ мьстахъ гды выжигали угли или золу. На песчаной почв' онъ почти никогда не встрьчается.

Употребляется въ пищу по всюду, только должно обращать внинаніе, чтобы прежде приготовленія, разрызать ихъ по длинь и осмотрыть ньтъ ли въ нихъ улитокъ или какихъ пибудь наськомыхъ и потомъ хорошенько вымыть въ водъ. При покупк' не должно брать старыхъ или не свъжихъ.

Ихт также сунать.

Сморчки выращиваютъ и искуственно, назначая для этаго мьста на дровяныхъ дворахъ около сложеннаго „ьсу, подъ заборомъ и тому подобное. Размноженіе ихъ въ этихъ мьстахъ дылается отрњзками остающимися при очисткь сморчковъ. 
Растительность ихъ усилится если эти мьста посыпать $30.10 ю$, на томъ основаніи, что и въ льсахъ находятъ ихъ лучшимя на выжигахъ. Утверждаютъ, что сморчки могутъ родиться самі собою сльдующимъ 06разомъ: въ тьнистыхъ льсныхъ мъстахъ, насыпаютъ на одинъ дюймъ золы, на нее кладутъ на одинъ футъ сушняку или соломы; при продолжительныхъ осеннихъ дождяхъ эту покрышіку уве.ичиваютъ, и весной шодъ ней находятъ множество сморчковъ. (См. A. von Bornholz die Cullur der Champ., Morsch., und Truffeln 1842).

Ножка у обыкновеннаго сморчка вышиною отъ однаго до полутора дюйма, цилиндрическая, снаружи ровная, рбдко изгибистая, внутри пустая, тускло бњлая, къ верху она разширяется и вокругъ верхушки ея о6разуется горизонтальное возвышеніе до двухъ линій шириною, къ которому прикрылена яицевидная шляка, дминою отъ однаго до трехъ дюймов'ъ, шириною отъ одного до двухъ дюймовъ. Снаружи почти четырехугольноячеистая, цвђта желтобураго иногда приближающагося къ бурооранжевому, ръдко темнобурому. 


\section{CTPA'LE'L, БАБУPА.}

\section{HELVELLA ESGULENTA, PER, HELVELLA MITRA, LINN,}

По Французски. Helvella comestible.

По Ньиецки. Die Frühlorchel, Stockmorchel, Maurane, Breitmorchel, Laurin.

Растетъ весною по льсамъ и возвышеннымъ лугамъ; любитъ особенно влажные и поросшіе мхомъ ныста.

Высушенные шляки страчковъ сохраняются ньсколько льтъ; предъ употребленіеиъ въ пищу ихъ надо разиочить въ горячей водь, чтобы уннчтожить непріятный запахъ, который они получаютъ пролежавъ долго сухими.

Ножка страчка въ верху цилиндрическая къ основанію утолщенная, большая ея часть находится обыкновенно въ зенль или во иху, длиною отъ половины до двухъ дюймовъ, гладкая б'ьоватая или красноватая, внутри часто пустая.

Шляпка обыкновенно безобразная, извнлисто-складчатая въ поперечникь отъ двухъ до трехъ дюймовъ черноватая, иногда темно-буро-бархатная. Нижняя поверхность во многихъ ньстахъ сростается съ ножкою, но морщинистые лоскусья толщишою до одной линіи ви- 


\section{Q2}

сять около нея. Внутренняя поверхность шляки весьма .неправильна, образуетъ, множество углубленій изъ которыхъ многіе покрыты тонкикъ бьлымъ пушконъ; вся внутренность ея однаго цвьта съ ножкою. Мякоть этаго гриба весьма ньжная, сдабаго запаха; цвьта одинаковаго съ верхней поверхностію.

Кругловатые съмйна заключены на поверхности гриба въ цилиндрическихъ мешечкахъ. 


\section{TPI0ФE.Ib. TUBER.}

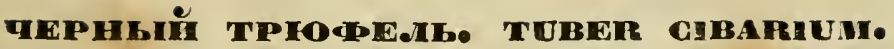

По Фрапцузски. Truffe noire Truffe d'hiver.

IIo Ньиецки. Trüfel schwamm, Erdschwamm, Trüffel weisse, schwarze ete.

По Англin̈ckir. Truffle, Trub, esculent pyff-ball.

Растетъ въ средней и южной Германіп, Богемін, Франціи, Италіи въ Россіи и ІІольшь. Во Франціи онъ встрьчается особенно въ изобиліп въ Дофине, Провансь и Перигорь считается лучшим и преинущественно употреблется для продажи.

Осеныо парпжскіе барыпнии объьзжагот всь деревні и городки, жители которыхъ занимаются собираніеиъ трюфе.ей и посылаютъ съ каждой почтой, въ Парижъ, чтобы доставить, свьжимг. Они укладываются въ решетчатыя корзины, безъ бумаги, чтобы свъжій воздухъ пиьлъ къ нимъ всегда свободный доступъ. Въ прохладную погоду можно удожнть въ корзипу до 20-ти фунтовъ, въ теплое же время около 12-ті, пиаче они сильно разгорячатся. Во время мороза пересылка пе надежна, замерзшіе при оттапваніи тераютъ свойственный имъ запахъ и скоро загииваютъ.

Въ Ліонъ привозятъ множество трюфелей изъ Дофине и Прованса; откуда они перепродаются въ Стразбургъ

YAcrb II. 
гдъ ихъ употребляютъ для знаменитыхъ стразбурскихъ пнроговъ. Изъ оппсанія Кейслера видно, что въ Піэмонть одинъ крестьянинъ въ годъ можетъ продать трюфелей на 70 таллеровъ. Онъ же пишетъ объ одномъ испалинскомъ трюфель, 12 фунтовъ въсу, который былъ проданъ въ Казаль за 4 луидора. Обыкновенно же четверть фунта, считается за большой в'ьсъ въ трюфель.

Собираютъ ихъ въ сухую погоду, когда нБтъ морозу; при сырой погод' онь съ трудомъ очнщаются, а въ морозъ легко замерзаютъ.

Растутъ въ рыхломъ и влажнопъ черноземб; въ дубовыхъ , буковыхъ и коштановыхъ льсахъ. Если большіе деревья будутъ срублены или такіе мьста порастутъ густымъ кустарникомъ, то трюфели обыкновенно пропадаютъ. Растутъ подъ землею на глубинь отъ однаго до двЂнадцати дюймовъ; большею частію отъ трехъ до семи виьсть, и если сидятъ не глубоко то подымаютъ землю, образуя бугорки обнаруживающіе ихъ присутствіе, почему опытныі искатель узнаетъ ихъ, а также и по свойственнопу имъ запаху, который въ зрьлыхъ трюфеляхъ слышенъ въ разстояніи нбсколькихъ футовъ; и наконецъ по стаямъ особенныхъ синеватыхъ мухъ, которые летаютъ надъ такой землею, чтобы класть въ нее свои яички. Крон' этаго употребляютъ для отысканія ихъ свиней если ньтъ дресированной собаки, только это тьщъ неудобно, что свиньей трудндо управлять и сверхъ того она ищетъ всякой всячины, найдя же трюфель съљдаетъ его, чтобы не допустить ее до этаго падьваютъ ей изъ широкаго ремня намордиикъ. Большею же частію употребляютъ собакъ, которые могуть быть всякой породы, но дучше избирать коротконогихъ съ тонкин чутьенъ и не пресльдующихъ съ жадностію дичи. Аресировка начинается твщъ, что ихъ корматъ трюфелями сваренными въ мо- 
докь, потомъ пріучають отыскивать спрятангые трюфели въ копнат'ь и наконецъ подъ открытымъ небомъ; награждая ихъ за каждую находку. Когда они привыкнутъ отыскивать трюфели въ льсу, то имъ дағотъ обык. новенную пищу.

Кто имъеть старую хорошо дресированную собаку, тому стоптъ только брать съ ней молодыхъ и опи отъ нее скоро научатся. Можно выучить собакъ и другпхъ образомъ именно, поноскою, употребляя для этаго только трюфель и всякій разъ, какъ она принесеть его давать ей за это что нибудь; потомъ заставлять отыскпвать, прикрывъ трюфель слегка землею, и наконецъ закопать по глубже. Интересно смотрыть на такую собаку въ льсу, гдњ она подобно охотничей бьгаетъ обнохивая зеило и если хорошо дреспрована, то найдя трюфель подаетъ голосъ, на который приходить пскатель осторожно вырываетъ находку лапатой пl очищаетъ отъ приставшей земли; сберегая въ прохладной, сухой, темной комнать, уложивъ такимъ образомъ, что бы они едва касались другъ друга, гд' они могутъ сохранится два пвсяца.

Въ продолженіи этаго времени должно тщательно осматривать, всюду ді они одинаково крыпки упруги и на ощупъ подобны пробк'. Если какое нибудь мьсто вдавливается или слышенъ непріятный запахъ, то это 0значаетъ испортившійся трюфель и его надо выбрасывать; поломанные или рызанные не погуть долго сохранится. Сильный толчекъ или давленіе производитъ порчу. Мокрота для нихъ очень вредна, потопу ихъ поготъ только предъ употребленіенъ въ пнщу, холодной водой. Острымъ ножемъ срьзываютъ наружнуг ихъ оболочку, до тьхъ пор'ъ пока покажется ираморная внутренность, употреб́ляя тотчасъ, 
и не обмывая вторично чтобы не уничтожить запаха. Разогрытые не вкусны.

Сберегають въ свиномъ жирь, въ которомъ кипетятъ пхъ снимая пьну, потомъ кладутъ на решета, и когда они остынутъ складываютъ въ муравленые банки и заливаютъ вновь скппеченныхъ свинымъ жиромъ, такъ чтобы онъ покрылъ пхъ пальца на два, и наконецъ банки хорошенько закупариваптъ и засмаливаюгъ. Этотъ способъ приготов.енія въ прокъ болье употребителенъ, потому что прн немъ трюфли могутъ сохрапятся два года. Если вмЂсто свинаго жира употребляется горовье пасло, то онп сохраняются четытыре мьсяца. Прп сохраненіп въ провансконъ онь сберегаются одинъ годъ. Бапкі съ трюфелями не ставятъ въ погребъ, но въ сухое и прохладное мьсто. Если же.латъ сохранить трюфели свъжими нысколько льтъ, то д.я этаго кладуть ихъ сухіе въ склянку съ широкимъ горломъ, ставятъ ее открытую въ воду, такъ чтобы гордо склянки находилось сверхъ воды; кипятятъ три часа, потомъ закупориваютъ, засма.иваютъ и ставятъ въ прохладное мьсто. Изръзаниые п.ластинами и высушенные, сохраняются очень долго, только при этонъ теряется нъсколько ихъ вкусъ. Въ времена 'девнихъ Римлиъ трюфе.и состав.яли лакомое блюдо. Таґъ каґъ цьна на нихъ всегда довольно высока, то по этому стали прндумывать средства разводить ихъ искусственно. Для этаго вырываютъ яму глубиною отъ трехъ до пятп футовъ, низъ и бока выстилагтъ г.иной, необожжеными кирпичами или калнями въ особенности хороши для этаго, известковые обкладка эта служитъ защитой отъ мышей и другихъ животныхъ, большихъ охотниковъ до трюфелей.

- Ямы эти наполняютъ землею взятой изъ яиственнаго лtсу, въ крайности только употребляютъ обыкшовенную садовую землю, которую орошенько перемтшиваютъ 
съ землею образовавшейся изъ дубоваго дерева и .истьевъ. Д.я окончательнаго наполненія ямъ приготовляотъ землю сльдующињ образомъ: Весног собираютъ коровій пометъ, лучше всего свъжій на выгонахъ, складываютъ его въ тенпстомъ шыст, и въ продолженіи льта, по чаще переворачивать поливая достаточно рбчной водою. Осенью къ этой земль примьшнаютъ отъ четверті до пятой доли, лиственной дубовой, или за неиньніеи такой, навозной содержащей въ себь большое количество ростительныхъ остатковъ, также весьма полезно примьшивать нзвестковаго мергеля, жельзпстаго песку, шлі жженую толченую пзвесть. Въ ію.' н.и августь отъ искиваютъ незрь.ые трюфели, вщьсть съ окружающей ихъ землею осторожно вынимаютъ, кладутъ въ ящикъ, и переносятъ къъ приготовленнымъ ямамъ, сажаютъ на четыре дюйма глуб́ны, такъ какъ онп были вынуты п окружаютъ той землею, въ которой они росли. Посльь посадки, если погода суха должно полить и покрыть в Бтками лиственныхъ деревъ; во время солнечнаго зноя пересадка рьдко удается. Если земля будетъ просыхать, то ее надо поливать; выросшія на этомъ мьсть большіе растенія выдергивать, небольшіе могутъ оставаться. Посьянные трюфели собпраются обыкновенно на другой годъ; черви ІІ другія наськоныя любятъ лакомнться трюф.ями; для уншчтоженія ихъ, посыпаютъ изрьдка известью истолченную въ порешокъ или дубовою золою.

Въ случађ еслі нельзя достать для посьва свьжихъ трюфелей, то приготов.енную зем.ю поливаютъ водою, въ которой они варились и бросагтъ въ нее остающіеся отъ нихъ очнстки.

Зрђлые тріофели велпчиной обыкновенно бываютъ съ картофель, снаружи черно-сьрые или черные, усажены частыми и жесткими бугоркамп, шежду которыми нахо- 
дитея тонкій пушекъ, онъ вьроятно замьняетъ корень; цвьтъ внутри въ началь былый, по мьрб же созрьванія переходитъ въ тусклобълый съ буроватыми жилками, отъ чего въ разрьзы представляется какъ бы мраморнымъ.

Сымяна находятся внутри, они чрезвычайно мълки. Растущіе на влажныхъ мьстахъ, оканчиваютъ свое существованіе сгнивая; въ сухой же почв', высыхаютъ . Еще не пзвъстно, какъ образуются молодые трюфели; пологаютъ только, что изъ однаго стараго, высохшаго, развивается четыре молодыхъ. Въ началь своего развитія они бываютъ величиною съ горошину въ виды красноватыхъ или фіолетовыхъ шарнковъ, удерживая этотъ цвьтъ до іюны ньсяца, который потощъ перехоАитъ в'b черныи. 


\section{ОПЕНОКТ ОБЫКНОВЕНШЙ.}

agaricus Cantareleus, Linn. Merulius Omphalia cantarellus, Pers.

По Французски, Chanterelle, Gerille, Chrevrille Jaunelet, etc.

По Нъмецки, Eyerschwamı, Rehling, Birkenschwamm, etc.

Растетъ по всюду въ Европь по льсамъ и кустарникамъ, но болье всего любнтъ березовые рощи. Показывается въ концы льта. Употребляется въ пищу свьжій и сушеный.

Ножка въ вышину отъ одного до двухъ дюйщовъ, желтая, къ верху разширяется и сливается со шляпкой, которая одинаковаго цвъта съ ножкой, имњетъ въ поперечникъ отъ двухъ до трехъ дюймовъ, вначалъ плоская, въ серединь пьсколько углубленная; въ старости дьлается воронкообразной, съ разрьзами по краямъ, которые бываютъ волнстье чынъ больше грибъ; шляпка не имъетъ снпаюшейся кожици. Пластинки толщиною ровняются плотной бущагъ, самые длинные изъ нихъ доходятъ до ножки и даже ньсколько по ней спускаются; у молодыхъ грибовъ онь бывають одиночные, поралельно расположенные одна подль другой, но чьмъ болье шляпа разростается тымъ болье онь у 
края шляпки ды.аются вытвистыми, раздыляясь на ньсколько выточекъ; когда шляпка достигаетъ полнаго развитія то пластинки походятъ на сьтку изъ жи.окъ. Весь грыбъ мясистый, запахъ пріятный, вкусъ нъсколько острый; онъ имьетъ предъ другими грибами то достоинство, что не такъ легко портится червями и вообще долго держится. 


\title{
MAG.ATHIIK'b. BOLETUS LUTEUS.
}

\author{
LINN.
}

По Ньмецки, Der Ringpilz.

Растетъ осенью въ хвойныхъ льсахъ на песчаной почвъ и у дорогъ. Такъ какъ онъ пнъетъ сочпую мякоть то его должно тотчасъ по собираніи употреб.ять въ пищу.

Ножка въ вышину отъ однаго до двухъ дюймовъ, въ толщину до трети дюйма, внутри бњлая снаружи свњт10 же.тая. Въ разстояніи на треть отъ верхняго копца, находится кожистое былое кольцо, часто соединяющее ножку съ шляпой, легко разрывающееся, впсить слабо-на кожиць, по мьрь созрьванія грпба дьлается бурой и потонъ изчезаетъ. Ножка внутрп бњла съ довольно твердою мякотью, хегко раздьляющеюся на продолговатые волокны. ІІляпка, толстая выпуклая, въ срединь съ значительнымъ возвышеніегъ или безъ онаго, шириною отъ двухъ до четырехъ дюймовъ, при сы- 
рой погод' слизистал, грязнобурая, впосльдствіи тускло-желтаго или эрко-же.лтаго цвђта; верхняя кожица тонкая и легко снимается; мякоть весища ньжная, желто-былая и сочная. Трубочги желтые; въ началь подобны самой тонкой проволокь, впосльдствіи разширяются. Мякоть и трубочки не измьняютъ цвыта при поврежденіи. 


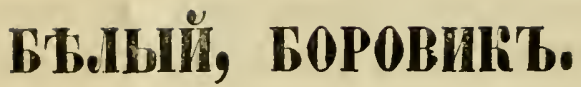

\section{BOLETUS EDULIS.}

BULL.

По Французски, Bolet comestible gyrole, etc.

По Ньиецкі, Der Steinpilz Bilzling.

Растетъ льтонъ и въ пачаль осени иногда даже въ мађ во всей Европь и по всякияъ льсамъ. Считается лучшинъ изъ грибовъ и по всельстно употребляется въ пищу. Въ прокъ заготовляютъ его сушеный и въ уксусъ. Когда грибъ молодъ, то при изготовленін, отъ него ничего не отбрасывается. Многіе животные ьдятъ его. какъ-то: волы, овцы, коровы, козы п проч. Докторъ Торъ пишетъ: Во Франціи въ департаменть Ландовъ сыютъ Boletus edulis. Для этаго выбираютъ зем.ю, поросшую дубовымъ дысомъ и поливаютъ водою, въ которой варнлось значительное колгчество этихъ грибовъ. Они не требуютъ за собою ні какого ухода, то.ько надо предохранить отъ животныхъ, которые ихъ Бдять .

Сдыланный много опытъ падъ пскуственнымъ разведыніемъ былыхъ грнбовъ, подобнымъ образомъ, не увенчался усп'хомъ; по первая пеудача не оетановитъ меня и ежели посльдүющіи опыты будутъ удовлетворительн, то я передаиъ о нихъ любителяп. Въ на- 
шемъ отечествь сухіе грибы составляютъ, почти необходимую принадлежность постнаго стола тьмъ бодье бы.ый грибъ, какъ лучшій; и потому чрезвычайно было бы полезно, еслибъ дълали болье опытовъ для разведенія его дешевымъ образомъ.

Ножка у молодаго гриба шаровидная или яицевидная, въ посльдствіи достигаетъ до шести дюймъ и болье вышины, почти цилиндрическая, внизу ньскольцо толще, бльдно-бурая, гладкая, внутри мякоть б'ьлая, твердая.

Шляпка выпуклая, темно или свьтло-бурая, гладкая, посль дожда иьсколько липкая; мякоть ее ньжная и бъ.ая въ верху немного бурая, толщиною отъ трети до дюйма и даже болье; шириною отъ однаго до двьнадцати дьймовъ. 


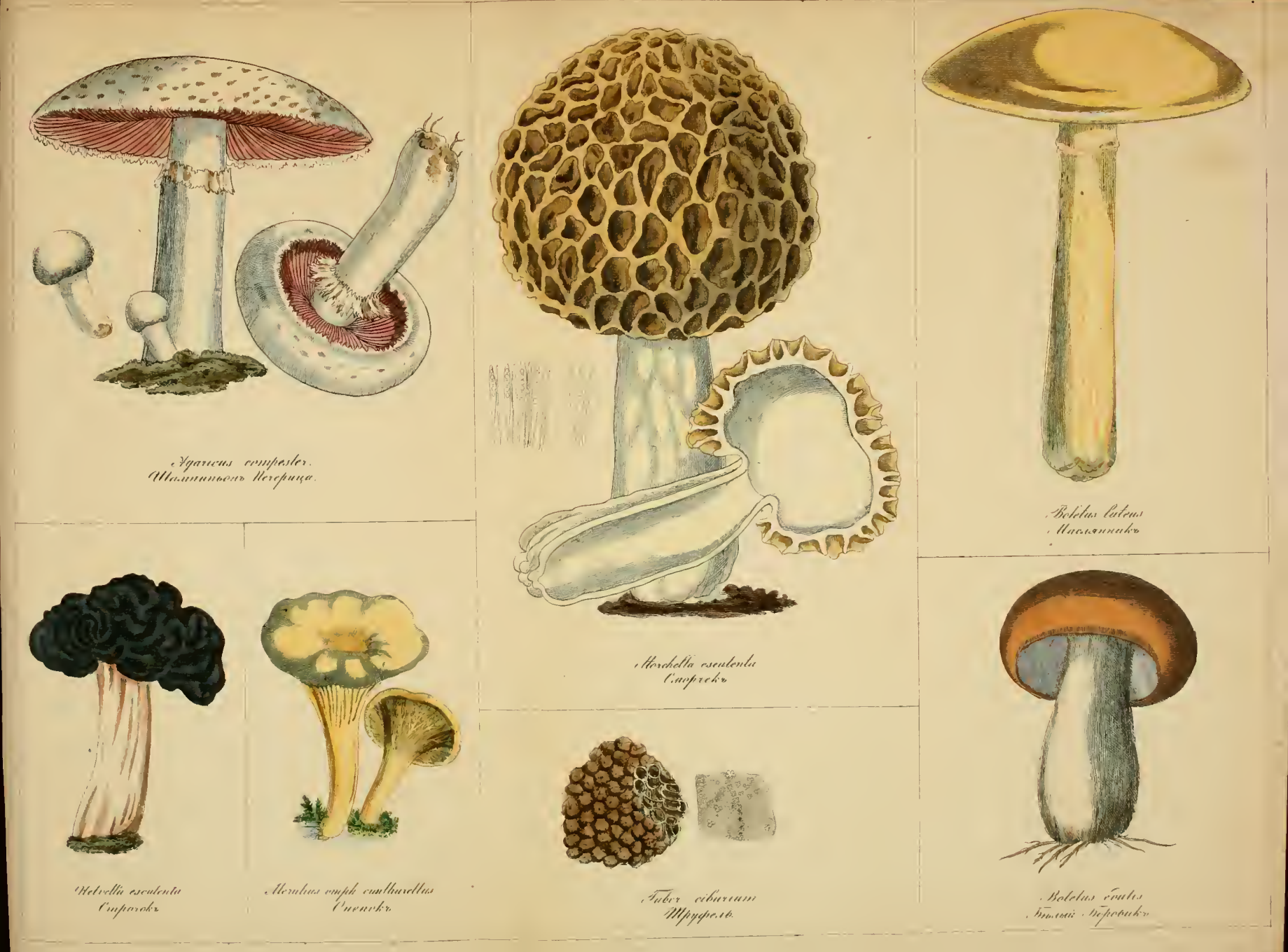





\title{
II0IJ0BУIIIIA.
}

\section{AGARICUS AMANITA.}

\author{
Procera.
}

IIо Французски, Couleuvrée, Parasol, Boutarot, Poturon. etc.

IІо Ньмецки, Parasolschwamm, Buberitze.

Растетъ во всьхъ Аьсахъ, въ концы льта и осенью.

Хотя поп.явушка не принадлежитъ къ числу вкусныхъ грибовъ; но занепьніеиъ дучшихъ можетъ употреблятся въ пищу. Въ Герпаніи, Фрапціи и Италіи, она по всеньстно употребляется. $У$ насъ же, ее до спхъ поръ ни гдь не употребляютъ въ пищу, причисдяя къ чис.лу поганонъ, иия данное напини крестьянами всьиъ вообще грнбалъ, которыхъ онь пе ьдятъ.

Ножка длинног отъ восьми до десяти дюймовъ, тодщиного около полъдюйма, при основаніи, раздута, утончается постепенно къ верьху, пмья почти па серединь кожпстое кольц, поверхпость ножк покрыта буроватыми чешуйками иди линіяи. Шляпка въ поперечшикь около шести дюймовъ, у молодаго гриба яицеобразная, а потомъ колокольчатая, въ полномъ развитін 
АБ.ается блюдообразною, съ кожистыми клочками по краямъ; наружный цв'тъ сьропьпельный, чешуйка буровато-темная. Мякоть бълая, мясистая, толщиною около полдюйма. Внутренняя сторона шляпки покрыта стоячими листочками, они въ началь бълы а потощъ буроваты или желтоваты. 


\section{OI.10ЕНТ ВАМШЕННЫЙ.}

\section{agaricus sQUamosus.}

Встрбчается осенью на зем.ь п.ии по гнилымъ пнямь, въ льсахъ средшей Европы. Вкусомъ походитъ на шампиньонъ. Ножкка отъ того иъста гды прикасалась въ неразвитомъ еще состояніп шляпа, до основанія желтоватая и вся въ чешуйках'ъ; верхняя же часть бълая, иякоть внутри тоже бьлая. Шяяпка чешуйчатая въ молодомъ грибъ полушаровидная, потощъ дьлается площе; пластинки на нижпей поверхности неровные, шеколадваго цвьта ил отдынены отъ ножки.

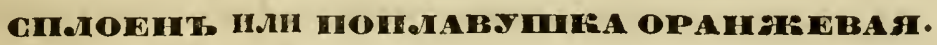
AGARHCUS AUTANTRACUS.

Ilo Французсги, Agaric orange, cadran, etc.

По Нъмецки, Der Keiserling.

Растетъ под' конецъ льта и осенью въ южныхъ и нькоторыхъ частяхъ средней Европы. Опъ еще пзв'ьстепъ былъ въ древности, Ринляне называлп его князенъ грнбовъ fungorum princeps. Шефферъ назвалъ этотъ грыбъ царской поплавушкой Amanita саesarea. Когда онь, только что, покажется изъ зем.и то он' будучи завернутъ въ бъ.ый наметъ или чахолъ, похожъ на не 
совершенно сваренное куриное яицо, у котораго желтооранжевый желтокъ покрытъ бъловатой ободочкой; потомъ наметъ разрывается и изъ него выходить оранжевая шляпка гриба; она бываетъ полушаровидная отъ четырехъ до шести дюйповъ ширины. Поверхность шляпки гладкая, безъ всякихъ пятенъ. Пластинки тодстые неровные, желтоватые, соединенные грыпко съ мякотью шляпки, не приросшіе къ корешку, который длинною отъ трехъ до шестп дюймовъ, снаружи желтоватобылыи а внутри бълый, на конць раздутый, съ основанія его окружаеть кольцо.

На рисункь представленъ грибъ средняго возроста и подъ нимъ завернутый въ наметъ съ разрьзомъ, чтобы видьть положеніе въ немъ гриба.

\section{CH.НОНТ УЕДПНЕННЫЙ. AGARICUS SOL- TARIUS.}

По Французски, Agaric, salitaire.

Растетъ во пногихъ среднихъ и южной странахъ Европы, льтомъ, по льсамъ и льснымъ лужайкамъ поросшимъ не высокою травою. Витадина и Летелье относютъ его къ грнбамъ употребляенымъ въ пищу. Считается однимъ изъ самыхъ крупныхъ грибовъ. Шляпка его въ пачаль округленная, потомъ плоская въ ширину отъ шести до восьми дюймовъ, поверхность усьяна остатками намета; мякоть мягкая и бьлая, въ шприну бываетъ часто болье трехъ дюймовъ; пластини постоянно утончаясь, доходятъ доножки имьющей въ вышину до шести дюймовъ, основапіе которой образуетъ родъ клубка; кільцо разорванное.

CH.IOEMT HaRHTOй. AGARECUS CONTORTUS.

Показывается въ іюпь и іюль при корнях деревьевъ, въ средней и южной Европ'ь.

Шляпка правильная, округленпая, съ выдавшеюся верхушкой, темнкоштановая, наружная поверхность 
сухая, изключая краевъ. Пластинки тонкіе, ломкіе, не прпросшіе къ корешку, который пзкрученъ полный у старыхъ грнбовъ и то рждко бываетъ трубчатый.

\section{CHOIOEUT MISEPOHTO AGARICUS WOUCERON.}

По Французски, Mousseron.

По Ньмецки,

Ростетъ въ южныхъ и немногихъ странахъ средней Европы. Яв.яясь весной посль продолжительныхъ теплыхъ дождей и во все льто по краянь льсовъ, по порубконъ и льснымъ лужайкамъ. Употребляется въ пищу свыщіиі и сушеный.

Mиогіе писатели подъ имянемъ мусеропа, описывали разлнчные породы грибовъ, какъ это видно изъ разногласія прнзпаковъ, но всь опь употребляются въ пाщщу .

Описываемый видъ, нечистаго бьлаго цвњта, иногда желтоватый, а иногда сьроватый, очень мясистый. Шляпка въ ширину около полутора дюйма, сначала шаровндная, потонъ очень выпуклая, наружная поверхность, сухая, гладкая, края внизу подогнуты. Пластинки узкіе въ близкомъ разстояніи одна отъ другой бъдые. Мякоть плотная лощкая бълая. Ножка короткая, цилиндрическая, частью углубленгая въ зем.ю, длинною вт полтора дюйма, ширнною въ полдюйма. 


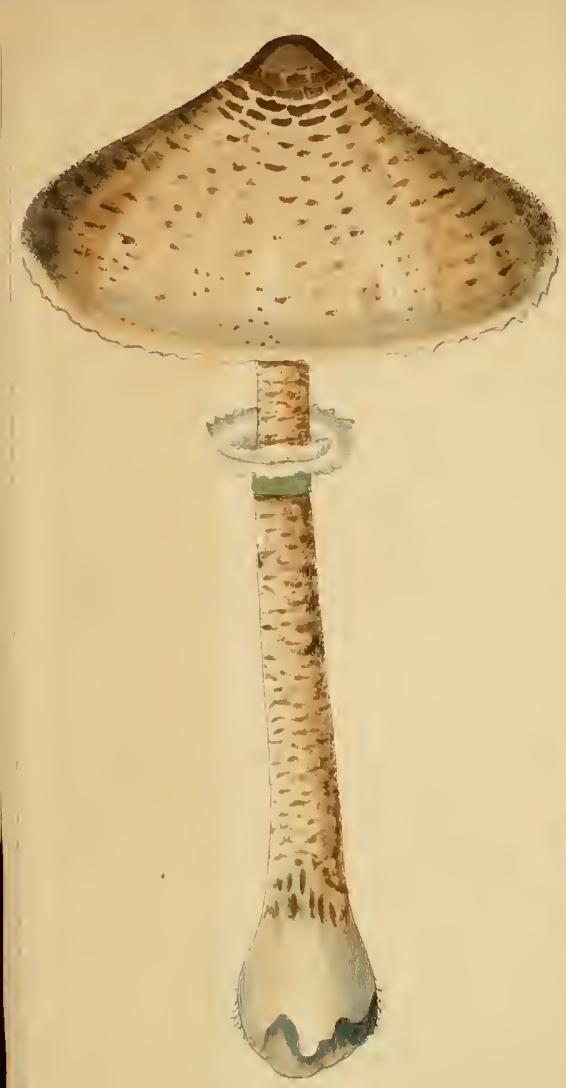

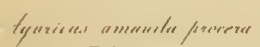
Trensorrinution.
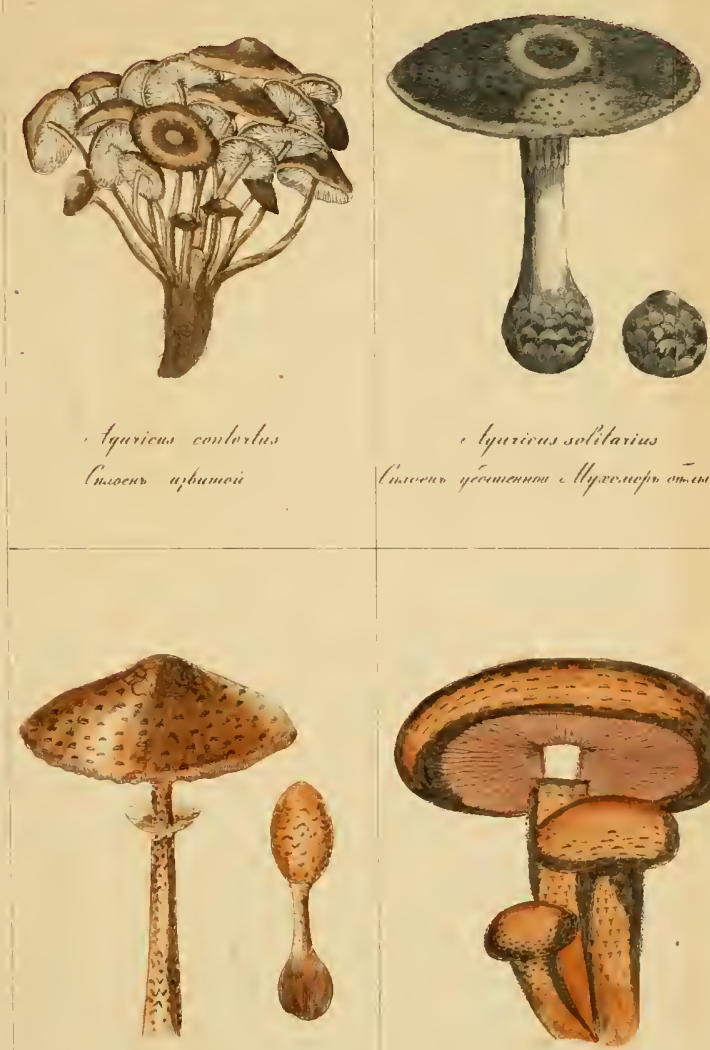

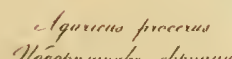

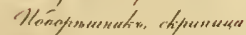

- Lyerirens solitariess

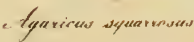

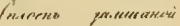
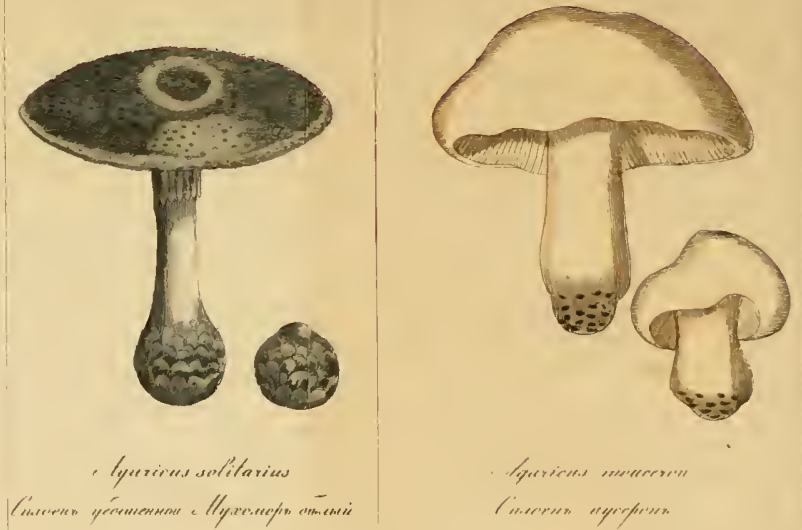

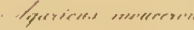

limereens uperficenx
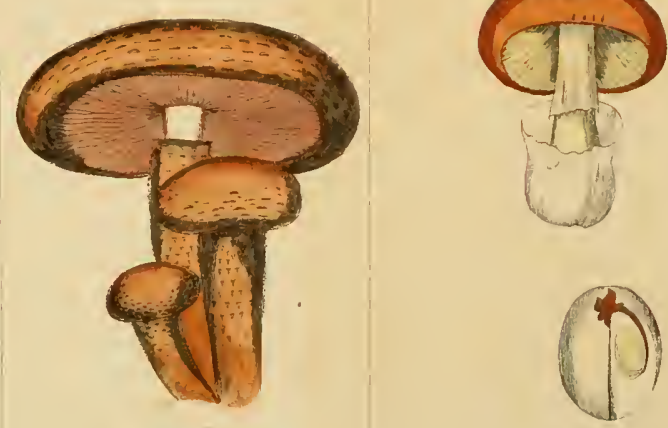



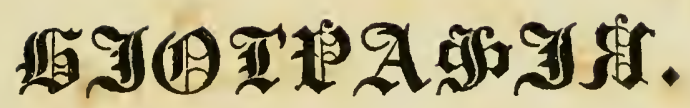




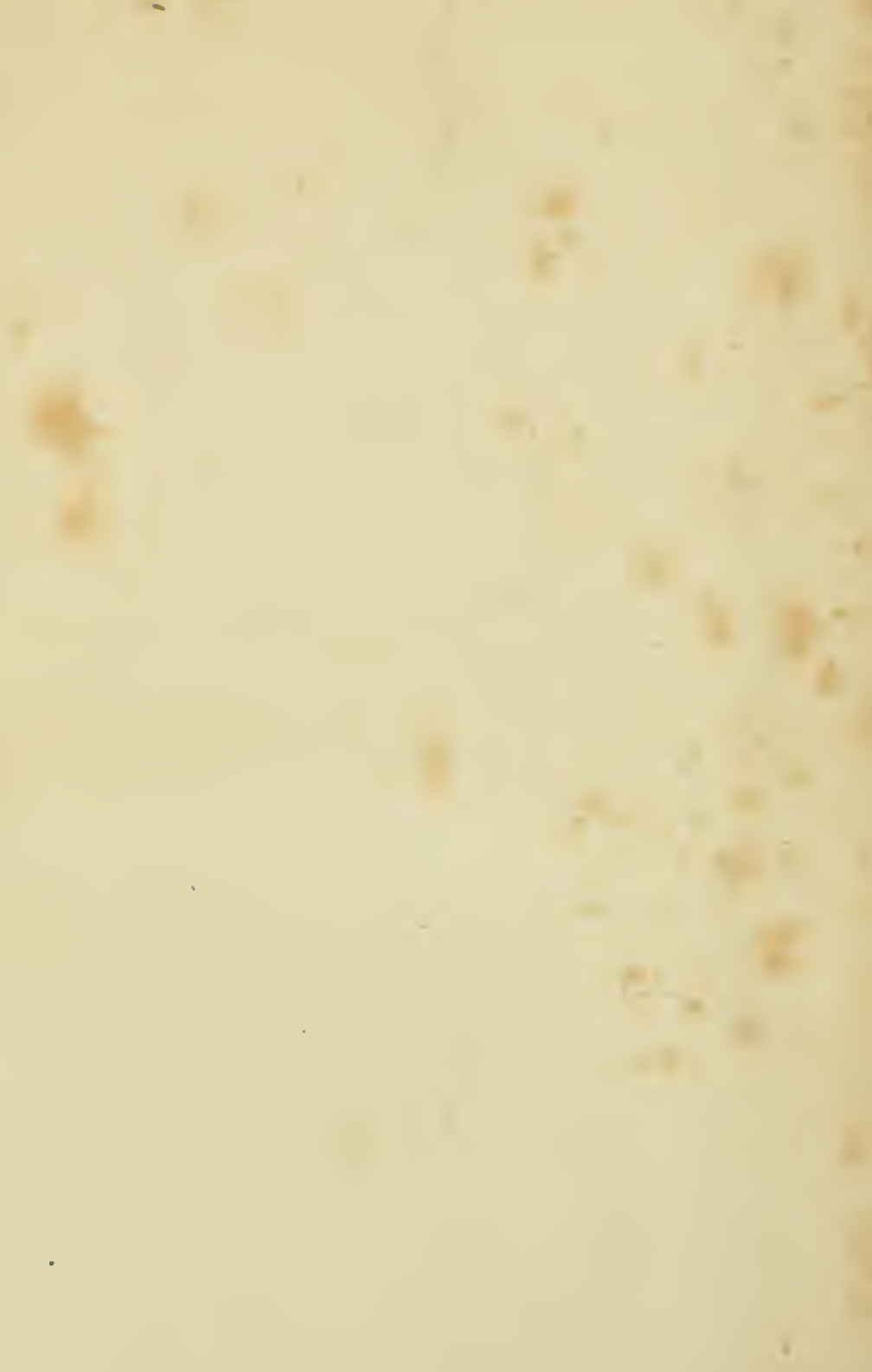


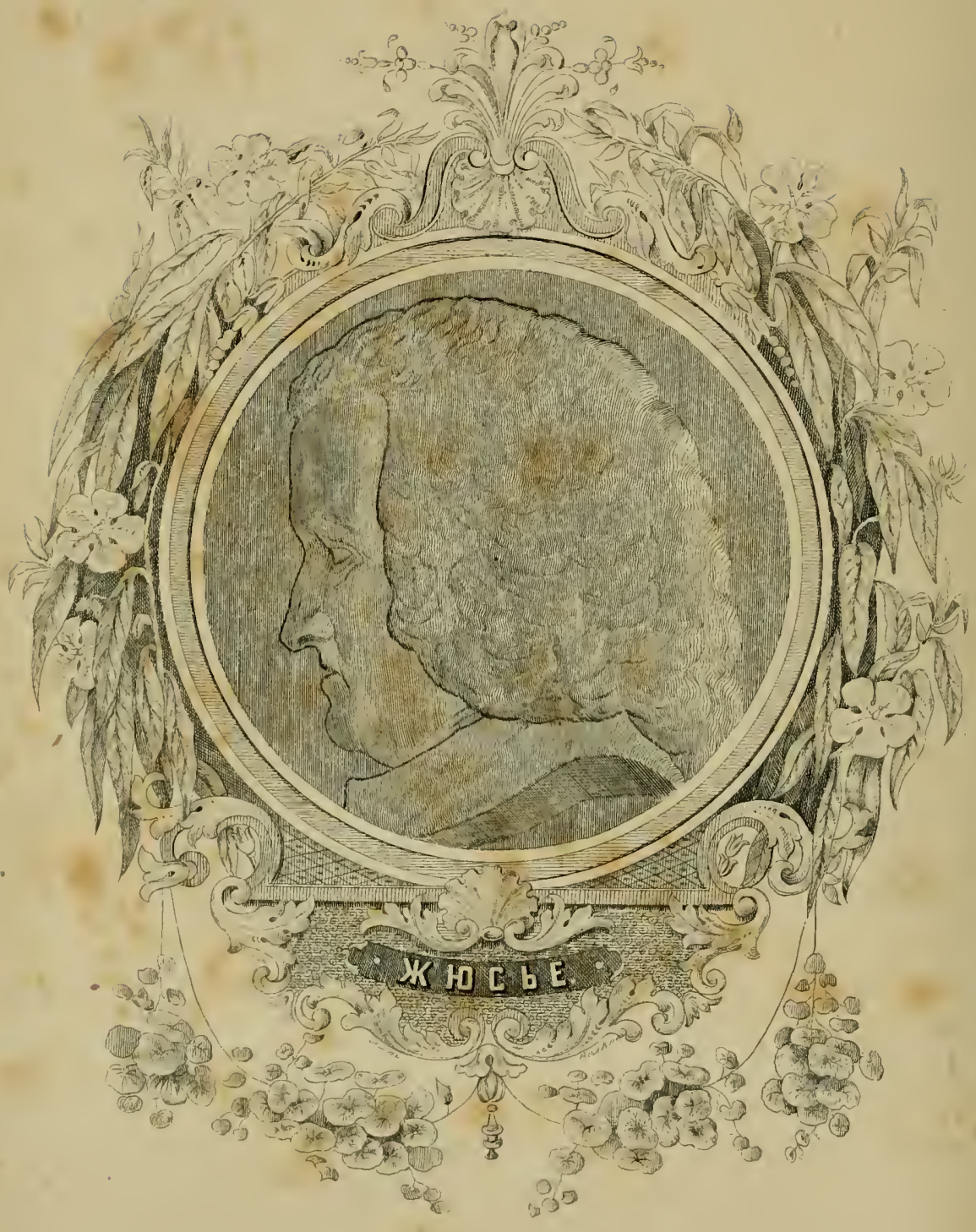

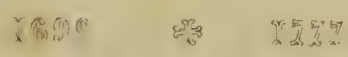




\section{БEРНAPЪ AE ЖWЮСЬË.}

Родился въ Ліоны 17 августа 1699 года. Семнадцати льтьъ вышель изъ учнлища и поьхаль въ Парижъ для окончанія курса наукъ. Въ то время Фагонъ (Fа. gon) посылалъ брата его Антонія де Жтосьё въ Испанію и Португалію, который взялъ съ собою Бернара. Это путешествіе утверди.о его въ прежнеи желаніп посвятпть себя изученію ботаннки. ПІо возвращеніп учнля медццнь и въ Моппелье (Montpellier) выдержалъ экзаменъ на степень доктора въ 1720 году; но чрезмьрная чувствите.ыность заставила его отказатся отъ шрактики, всльдствіе чего онъ возвратился въ Парнжъ II спустя два года устар'вшій Вальянъ (Vaillant) пред.ожилъ ему занять его мысто преподователя ботаники въ кородевсконъ саду.

Двадцати шести льтъ издалъ вторично съ дополнепіящ Исторію растеній въ окресностяхъ Парпжа, Турнєфора; былъ выбрапъ членомь Академіи наукъ п пріобрьль Европейскую извъстиость. Не сліоря на это Бернаръ во всю жизнь остался въ скропноп званіи, которое занял посль смерти Вальяна; онъ ииьлъ па ботаннуу і вообще на натуральную псторію вліяніе, составивште эпоху въ паукь. Ширакъ (Chirac), заступившій мьсто Фагона въ управленіи королевския са- 
домъ, привелъ въ упадокъ преподаваніе ботаники; деньгамъ, отпускаемымъ на издержки по этому предмету, онъ давалъ другое назначеніе, и не разъ Антоній Жюльё употреблялъ на это свои деньги. Бернаръ въ свою очередь удвонлъ стараніе, чтобы поддержать преподаваніе, равно какъ и обработку королевскаго сада. Естественный сборникъ, коего онъ былъ хранителеиъ, получилъ значительное распространеніе пा принялъ названіе королевскаго кабинета. Но всего болtые высказывался блестящияъ образощъ талантъ его при собира ніи травъ по полямъ. Тахъ-то застав.ялъ онъ удив.яться своему рвенію, своимъ познаніямъ и особенно неистощимому терпьнію. Ученики его часто надовдали ему пустыми вопросами и сверхъ этаго старались иногда смышать его, псказивъ нызкоторыя растенія или составляя одно пзъ разныхъ, надыясь напасть на него въ распхохъ, пІ потонъ изъ подтишка посмьяться; но Бернаръ скоро открывалъ ихъ хитрости, называлъ растеніе, мъсто гдђ обыкновенно расло оно и свойства, которыя въ немъ уничтожнли или исказн.и. Во время пребыванія своего въ Парижъ, Линней сопутствовалъ Бернару въ одной изъ такихъ прогулокъ, и когда ученнки сдылалп съ нимъ тоже подобный обманъ, то шведскій ботаникъ возвращая ищъ искаженное такищъ образощъ растеніе сказалъ: “Aut Deus, aut Dominus de Jussieu» т. е. Одинъ Богъ ини учитель вашъ Жюсьё можетъ назвать ващъ его.

Ньсколько льтъ Жюсьё обдумывалъ о природныхъ сходствахъ, существующихъ между растеніяп, желая перейдти отъ подробностей науки къ ея общеродовымъ свойствамъ, и въ молчаніи собиралъ запасы для системы, которая до сихъ поръ носитъ его пмя. Но чрезмьрная скромность и любовь къ истинь мешали ему что либо напечатать въ продолжепін жизни, кронь очень малаго числа записокъ, превосходныхъ впрочелъ, 
о нькоторыхъ отды.дьыхъ растеніяхъ; запискі этн ииъли связь съ великими доводами имъ приготовляемыми. Онъ сдьлалъ также ньсколько опытовъ падъ полипами помьстивъ ихъ въ царство животныхъ и изучнлъ свойство коралла. Въ 1749 году открыль, что детучая щелочная соль уничтожаетъ дыйствіе зиьнаго яда.

Возвратясь нзъ путешествія въ Англію, въ 1734 году, онъ привезъ въ иляпь два .Іиванскихъ кедра, изъ которыхъ одннъ до сихъ поръ существуетъ в'ъ саду музеума и самый древньйшій изъ находящихся во Францін. Огъ имьль удовольствіе видыть какь это дерево росшее на глазахъ его, возвысн.ось надъ высочайшими деревьями сада.

Счаст.ливое обстояте.льсто дозво.н.ло ему при.ожпть къ дЂ.лу его великія воззрьнія, которыя безъ того, можетъ быть, остались бы потерянными д.я науки. Людовикъ $\mathrm{XV}$ захотьль устропть, въ саду Тріанона, ботаническую школу, и Бернара назначили псполнителемъ этаго памьренія въ 1758 году. По этому случаю онъ иньљъ частыя свпданія съ королемъ, которому очень нравнлся его разговоръ, исполненный знанія, простоты и чистосердечія; но изъ этого рода сношеній ему осталось одно только всегда пльнительное удово.ьствіе даже и для Философа, удовольствіе видьть близко человыка, отъ котораго зависитъ участь двадцати пилліопвъ жюдей. Онъ пичего пе просилъ и ему ничего не дали; не вознаградпли даже издержекъ, дълаемыхъ по частнымъ его путешествіям. Однако король не забывалъ въ продолженіи его нъсколькихъ льтъ потомъ; онъ пересталь вызывать его въ Тріанонъ гды его присутствіе не было болье полезно, но часто говорилъ о немъ съ участіемъ. Подобный человькъ дыйствительно до.женъ былъ остав.ять глубокіе сльды, особенио въ уиь короля обреченнаго видьть почти всегда одиихъ только прндворныхъ. Скромность Жіосьё была чрезмьрна: часто онъ 
отвьчалъ на ды.лаемые ему вопросы: Я не знаю; и от вБтъ этотъ приводи.љ въ заньшательство совьтующи хся съ нимъ, устыженныхъ такниъ образомъ въ томъ, что они считали себя ученъе его. Онъ ненавпдълъ шарлатанство, но прощалъ шарлатанамъ. Пріятная веселость и шутки безъ желчи, при добродушіи дълали восхитительными разговоры его съ друзьям, тогда то онъ начиналъ невинную войну съ нькоторыми мньніями, не не называя однако по имени тЂхъ, кому они принадлежалII.

Система Линея пользовалась въ это время всемірнымъ довьріемъ. Жосьё болье и болье убеждаясь, что классификація должна основываться на общности сходныхъ свойству и обсудивъ относительный ихъ порадокъ, расположнль школу сообразно съ этнмъ.

Онъ раздьлиљ прежде всего всю систему на два болышихъ отдыленія однополовинчатыя (monocotylédonées) и двуполовипчатыя (dicotylédonées); потомъ распредълилъ устройство и сенейства по сходству общихъ свойствъ, и не пзлагая причинъ такого совершенно новаго распреды.ленія, ограничился изданіемъ простаго каталога Тріанонскаго сада. Это, правда, значило на самомъ грунть начертать планъ прнроднаго порадка, имъ постигнутаго, позднье распространеннаго членощъ его сенейства не менье знаменитым .

Бернардъ де Жюсьё соедипяъ въ себъ два качества обыкновенно весьна противуположныя: страстную любовь къ наукь и совершенную безпечность къ почестямъ, которыя могъ бы извлечь изъ свонхъ трудовъ. Когда ему давали замьтить, что другіе присвоивали себъ одпо изъ его открытій, онъ отвычалъ: Что за бъда! только бы было признано. Эти два качества, равно какъ п самоотверженіе, которое не допускало его сопернічать съ кьмъ бы то нибыл, давали блдыной въсъ его ниьиямъ. Несмотря на расположеніе къ нему короля, 
Берпарт де Жосьё никогда пе просиль ни какой милостн.

Жапъ Жакъ Руссо, изучавшій ботаннку, поручплъ спросить у Жосье, какой методы долженъ опъ сльдовать: никакой, отвжчаль Бернаръ: пусть изучаетъ онъ растенія, въ томъ порядк' въ какоиъ природа ихъ представляетъ, и пусть разињщастъ ихъ по тымъ сходствамъ, которыя наблюденіе открываетъ между пим. Невозможио, прибавиль онь, чтобы человьк съ его достоинствани, запимаясь ботаникою, не научиль насъ чену нибудь.

По сиерті брата его Антоиія, котораго любнлъ и уважаль опъ какъ отца, ему предложнли, упразднениую кафелру, но онъ ея не прннлъ. “Старики не любятъ шерешыны,» сказаль онъ. Лемонье (Lemonnier) получн.Іъ всльдствіе этого отказа первое мьсто, а Бернаръ остался на второмъ. Іђсколько льтъ спустя, онъ вызва.ль къ себъ племяника, Антонія Лорена ЖКюсье (Antoine Laurent de Jussieu), котораго паправляль онъ къ пзученію естественныхъ наукъ и умеръ 16 ноября 1777 года. 





\section{QK50.R65 York Botanical Garden Library \\ Romanov, P. V./Vseobshchaia flora dlia I

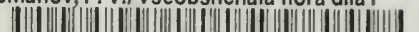

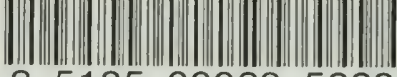 \\ 35185000295228}


